Report No. BMI-1430

UC-25 Metallurgy and Ceramics (TID-4500, 15th Ed.)

Contract No. W-7405-eng-92

\title{
PROGRESS RELATING TO CIVILIAN APPLICATIONS DURING MARCH, 1960
}

by

Russell W. Dayton

Clyde R. Tipton, Jr.

April 1, 1960

\section{BATTELLE MEMORIAL INSTITUTE 505 King Avenue \\ Columbus 1, Ohio}




\section{DISCLAIMER}

This report was prepared as an account of work sponsored by an agency of the United States Government. Neither the United States Government nor any agency Thereof, nor any of their employees, makes any warranty, express or implied, or assumes any legal liability or responsibility for the accuracy, completeness, or usefulness of any information, apparatus, product, or process disclosed, or represents that its use would not infringe privately owned rights. Reference herein to any specific commercial product, process, or service by trade name, trademark, manufacturer, or otherwise does not necessarily constitute or imply its endorsement, recommendation, or favoring by the United States Government or any agency thereof. The views and opinions of authors expressed herein do not necessarily state or reflect those of the United States Government or any agency thereof. 


\section{DISCLAIMER}

Portions of this document may be illegible in electronic image products. Images are produced from the best available original document. 

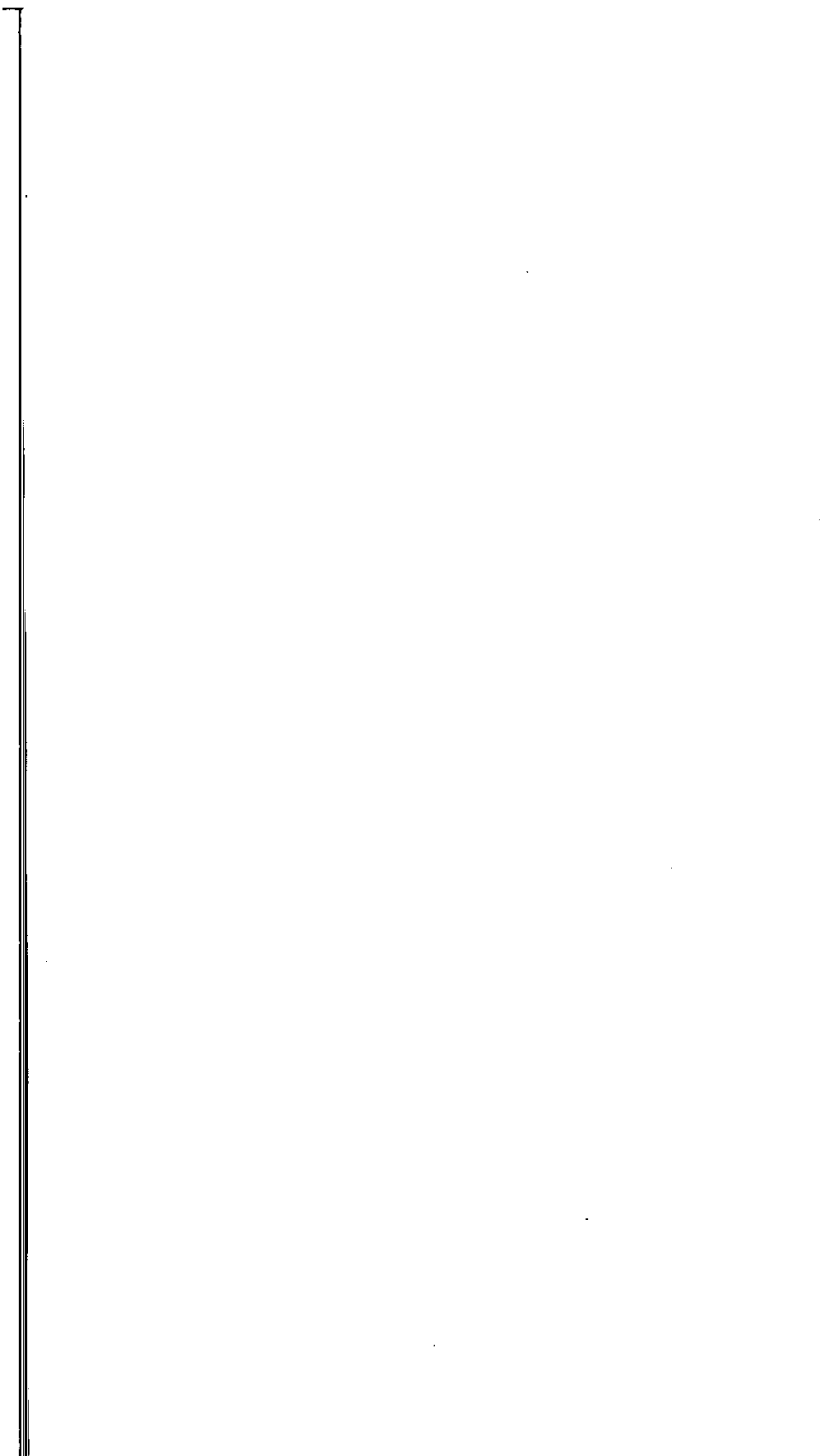

. 
A. REACTOR MATERIALS AND COMPONENTS (AEC-DRD)

A-1

Valence Effects of Oxide Additions to Uranium Dioxide . . . . . . . . . A-3

High-Pressure High-Temperatu re Solid-State Studies . . . . . . . . . . . . . . . . . . A-4

Irradiation-Surveillance Program on Type 347 Stanless Steel . . . . . . . . . . . . . . . . . A-5

Development of Corrosion-Resistant Niobium Alloys . . . . . . . . . . . . . . . . . . . . . . . . . . . . . . . . $\quad$ A-8

Investigation of the Creep Properties of Zircaloy-? During Irradiation at Elevated Temperatures . . A-8

Determination of Oxygen in Sodium at Concentraticins Below 10 PPM . . . . . . . . . . . . . . . . . . A-13

Wear and Friction of Sliding Surfaces in Liquid Sodium . . . . . . . . . . . . . . . . . . . . . . . . . . A-14

13. STUDIES OF FUEL ALLOYS (AEC-DRD) . . . . . . . . . . . . . . . . . . . . . . . . . . B-1

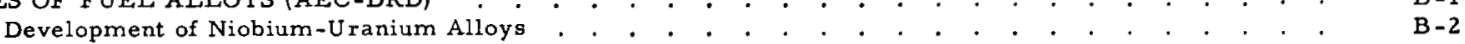

Development of Thorium-Uranium Alloys . . . . . . . . . . . . . . . . . . . . . B-4

$\therefore$ FISSION-GAS RELEASE FROM REFRACTORY FUELS (AIC-DRD) . . . . . . . . . . . . . . . . . . C-1

Characterization of Sintered $\mathrm{UO}_{2}$ and Model of Gas Release . . . . . . . . . . . . . . . . . C C-2

Diffusion in $\mathrm{UO}_{2}$.

Preparation for In-Pile Study . . . . . . . . . . . . . . . . . . . . . . . . . . . . . . . C C-4

1). GENERAL FUEL-ELEMENT DEVELOPMENT (AEC-DRD) . . . . . . . . . . . . . . . . . . . . . D-1

Fabrication of Cermet Fuel Elements . . . . . . . . . . . . . . . . . . . . . . . D-2

Gas-Pressure Bonding of Molybdenum- and Niobium-Clad Fuel Elements . . . . . . . . . . D-3

Factors Affecting Pressure Bonding. . . . . . . . . . . . . . . . . . . . . . . . . . . . $\quad$ D-4

1. GAS-PRESSURE BONDING OF CERAMIC, CERMET, ANI) DISPERSION FUEL ELEMENTS

(AEC-FUEL CYCLE) . . . . . . . . . . . . . . . . . . . . . . . . . . . . . . E E-1 Uranium Dioxide Compaction Studies . . . . . . . . . . . . . . . . . . . . . . Gas-Pressure Bonding . . . . . . . . . . . . . . . . . . . . . . . . . . . E-2

J. DEVELOPMENT OF URANIUM CARBIDE (AEC-FUEL CYCLE) . . . . . . . . . . . . . . . . F-1 Alternate Fabrication Methods for UC . . . . . . . . . . . . . . . . . . . . . . F-2 Melting and Casting Techniques for Uranium-Carbon Alloys. . . . . . . . . . . . . . . . . . . . $\quad F-4$ Mechanical and Physical Properties of Uranium Mionocarbide . . . . . . . . . , . . . . F-5 Uranium Monoca rbide Diffusion Studies . . . . . . . . . . . . . . . . . . . . . F-7 Irradiation Effects in UC . . . . . . . . . . . . . . . . . . . . . . . . . . . . . . . . . . . . . . . . $\quad$ F-8

(i. PHYSICAL RESEARCH (AEC-DR) . . . . . . . . . . . . . . . . . . . . . . . . . . G-1 Thermal Migration of Hydrogen in Zirconium . . . . . . . . . . . . . . . . . . . G G-2 Fusion Methods to Prepare Single Crystals of UO 2 . . . . . . . . . . . . . . . . . . . G-2 Growth of $\mathrm{UO}_{2}$ Crystals From the Vapor Phase . . . . . . . . . . . . . . . . . . . G-3

Il. RADIOISOTOPE AND RADIATION APPLICATIONS (AEC-OID) . . . . . . . . . . . . . . . . . . H-1 Development of Radioactive-Tracer Ruality-Contrcil Systems . . . . . . . . . . . . . . H-2 Use of Intrinsic Radioactive Tracer for Process Control . . . . . . . . . . . . . . . . . . . . . . H-3 Graft-Polymerization Studies . . . . . . . . . . . . . . . . . . . . . . . . . . $_{\text {H-4 }}$ Nitration of Hydrocarbons . . . . . . . . . . . . . . . . . . . . . . . . . . H-5

I. $\cdot$ VOID-DISTRIBUTION AND HEAT-TRANSFER STUDIES (AEC-EURATOM) . . . . . . . . . . . . . . . . . I-1

J. MATERIALS DEVELOPMENT AND EVALUATION (HAPO) . . . . . . . . . . . . . . . . . . J-1 Mechanical Properties of Zirconium Alloys , . . . . . . . . . . . . . . . . . . . . . . . . . $\quad \mathrm{J}-2$

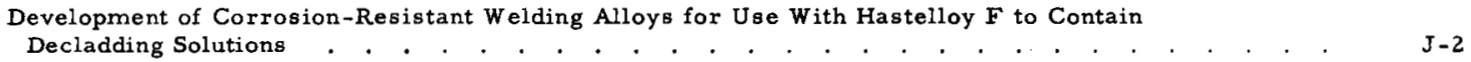

. . DEVELOPMENTS FOR ALUMINUM-CLAD FUEL ELEMEIUTS $(S C L)$. . . . . . . . . . . . . . . . . . . . . K-1 Preparation of Aluminum-Uranium Alloys . . . . . . . . . . . . . . . . . . . . . $\mathrm{K}-2$ A Study of Aluminum-Uranium-Nickel Eutectic Ternperature . . . . . . . . . . . . . . K-3 
L. REFLECTIVE-INSULATION STUDIES (KAISER) . . . . . . . . . . . . . . . . . . . . . . . . . .

M. PROBLEMS ASSOCIATED WITH THE RECOVERY OF SPENT REACTOR FUEL ELEMENTS (ORNL).

Corrosion Studies of the Fluoride-Volatility Process . . . . . . . . . . . . . . . . . . . . . .

$M-1$ Study of the Effects of Irradiation on Cladding - and Core-Dissolution Processes . . . . $\quad \mathrm{M}_{-2}$

N. VARIABLE-MODERATOR REACTOR CRITICAL-ASSEMBLY STUdIES (ATL-A) . . . . . . . . . . . . . N-1

O. URANIUM CARBIDE AS A REACTOR FUEL (AI) . . . . . . . . . . . . . . . . . . . . . . . . . . O-1

Irradiation of Uranium Monocarbide . . . . . . . . . . . . . . . . . . . . . . . . . . . . . . . . . . $\quad . \quad 0-2$

Postirradiation Examination of Uranium Monocarbide . . . . . . . . . . . . . . . . . . $0-2$

P. PEBBLE-BED REACTOR MATERIALS (E \& P) . . . . . . . . . . . . . . . . . . . . . . . . . . . . . . . .

LABORATORY EVALUATION OF FUELED-GRAPHITE SPHERES . . . . . . . . . . . . . . . . . P-2

FABRICATION DEVELOPMENT OF COATED FUEL PARTICLES . . . . . . . . . . . . . . . . . . P-2

$\mathrm{Al}_{2} \mathrm{O}_{3}$-Coated $\mathrm{UO}_{2}$. . . . . . . . . . . . . . . . . . . . . . . . . . . . . ${ }^{\mathrm{P}-2}$

Carbon-Coated Uranium Carbide

Carburization Studies. . . . . . . . . . . . . . . . . . . . . . . . . . . . P-3

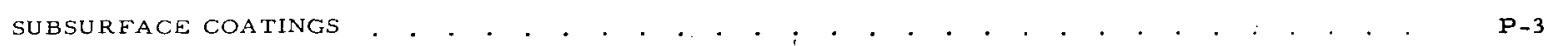

FISSION-PRODUCT RELEASE FROM FUELED-GRAPHITE SPHERES . . . . . . . . . . . . . . . . . P-4

Neutron-Activation Studies . . . . . . . . . . . . . . . . . . . . . . . . . . . . . . . . . . . . . .

In-Pile Capsule Experiments . . . . . . . . . . . . . . . . . . . . . . . . . . . . . .

Q. TANT ALUM AND TANTALUM ALLOYS FOR LAMPRE APPLICATIONS (LASL) . . . . . . . . . . . . . . . . Q-1 Development of Container Materials for LAMPRE Applications . . . . . . . . . . . . . . . . $\quad$ Q-2

Effect of Irradiation Damage of Tantalum . . . . . . . . . . . . . . . . . . . . . . . . . . . . . . . $\quad \begin{array}{llll} & Q-2\end{array}$

Precipitate Phase Identification and Interstitial-Type Solid Solubility in Tantalum . . . . . . . . . $\quad$ Q-3

S. DEVELOPMENT OF MATERIALS FOR THE MGCR AND HTGR (GA) . . . . . . . . . . . . . . . . . S-1

High-Burnup Irradiation Effects in Fuel Materials . . . . . . . . . . . . . . . . . . . S-2

Carbon-Transport Corrosion Studies . . . . . . . . . . . . . . . . . . . . . . $\quad$ S-3

Thermal Conductivity of Beryllia . . . . . . . . . . . . . . . . . . . . . . . . . . . . . . . . . . . . $\quad . \quad$ S-3

Preparation and Coating of Uranium and Thorium Carbide Powders . . . . . . . . . . . . . . . S

T. DEVELOPMENTAL STUDIES FOR THE SM-2 (ALCO) . . . . . . . . . . . . . . . . . . . . . . . T-1

Materials Development . . . . . . . . . . . . . . . . . . . . . . . . . . . $^{\mathrm{T}-2}$

Encapsulation Studies . . . . . . . . . . . . . . . . . . . . . . . . . . . .

Fuel-Element Thermodynamics . . . . . . . . . . . . . . . . . . . . . . . . . . . . . . .

U. GAS-COOLED REACTOR PROGRAM (AGN) . . . . . . . . . . . . . . . . . . . . . . . . . U-1

Fabrication of BeO-UO 2 Fuel Pellets . . . . . . . . . . . . . . . . . . . . . . . . . . . . . . . . U U

Study of Processing Variables in the Fabrication of $\mathrm{BeO}-\mathrm{UO}_{2}$ Ceramics . . . . . . . . . . . . . . $\mathrm{U}_{-2}$

Encapsulation Studies . . . . . . . . . . . . . . . . . . . . . . . . . . . U-4

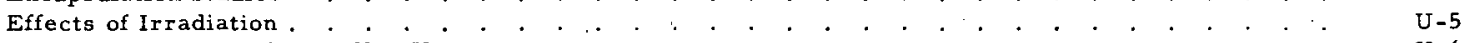

Alloy Modification of Hastelloy $X$. . . . . . . . . . . . . . . . . . . . . . . U U-6

GCRE Critical-Assembly Experiments . . . . . . . . . . . . . . . . . . . . . . . . . . . . . . $\quad$. U.7

BRR Loop Program . . . . . . . . . . . . . . . . . . . . . . . . . . . . . . . . . . . . . . . . . . . $\quad . \quad$ U-7

ETR Loop Program . . . . . . . . . . . . . . . . . . . . . . . . . . . . . . . $\quad$ U-8

V. CORROSION OF THORIUM AND URANIUM UNDER STORAGE CONDITIONS (LIVERMORE) . . . . . . . . . V-l

Electrodeposited Coatings for Thorium (SC) . . . . . . . . . . . . . . . . . . . . . . . . . . $\quad$ V-2

Corrosion Evaluations (UCRL). . . . . . . . . . . . . . . . . . . . . . . . . . . . . . . . V-2 
5 and 6

\section{REPORTS RELATING TO CIVILIAN APPLICATIONS}

ISSUED DURING MARCH, 1960

BMI-1391

(Rev.)

BMI- 1415

BMI- 1416

BMI- 1418

BMI- 1420

BMII- 1422

BNII- 1423

BN.I- 1426
"Progress Relating to Civilian Applications During October, 1959", by Russell W. Dayton and Clyde R. Tipton, Jr.

"Radiometric Methods for the Determination of Magnesium and Calcium in Portland Cement", by Charles T. Brown, James E. Howes, Jr., Thomas S. Elleman, Charles W. Townley, and Duane N. Sunderman.

"Examination of a Nonregenerative Heat Exchanger from the U.S.S. Nautilus (SSN-571)", by Warren E. Berry, Oliver M. Stewart, and Frederick W. Fink.

"Development of High-Strength Corrosion-Resistant Zirconium Alloys", by John A. DeMastry, Frederic R. Shober, and Ronald F. Dickerson.

"Effects of Yttrium on the Fabrication and Tensile Properties of Two Modified Stainless Alloys", by John A. DeMastry, Frederic R. Shober, and Ronald F. Dickerson.

"Numerical Solution of Fuel-Element Thermal-Stress Problems", by Robert F. Redmond, Harry Pollack, Alton E. Klickman, William S. Hogan, William M. Epstein, and Joel W. Chastain.

"Progress Relating to Civilian Applications During February, 1960, by Russell W. Dayton and Clyde: R. Tipton, Jr.

"The Diffusion of Hydrogen in Zirconium Hydride", by William M. Albrecht and W. Douglas Goode, Jr. 
6

$=$ 
REACTOR MATERIALS AND COMPONENTS (AEC-DRD)

\author{
R. F. Dickerson
}

\begin{abstract}
Valence Effects of Oxide Additions to Uranium Dioxide . . . . . . A-3 High-Pressure High-Temperature Solid-State Studies . . . . . . . A-4 [rradiation-Surveillance Program on Type 347 Stainless Steel . . . . A-5 Development of Corrosion-Resistant Niobium Alloys . . . . . . . A-8 [nvestigation of the Creep Properties of Zircaloy-2 During Irradiation at Elevated Temperatures. . . . . . . . . . . . . . . A-8 Determination of Oxygen in Sodium at Concentrations Below 10 PPM . . A-13 Wear and Friction of Sliding Surfaces in Liquid Sodium . . . . . . A-14
\end{abstract}

As a part of the study concerned with stabilization of $\mathrm{UO}_{2}$, it has been observed that the lattice parameters of $\mathrm{U}_{3} \mathrm{O}_{8}-\mathrm{La}_{2} \mathrm{O}_{3}$ solid solutions are larger than those reported in the literature. These results indicate that the published data may have been obtained from solid solutions of $\mathrm{UO}_{3}-\mathrm{La}_{2} \mathrm{O}_{3}$ rather than $\mathrm{U}_{3} \mathrm{O}_{8}-\mathrm{La}_{2} \mathrm{O}_{3}$. Microbalance analyses will be carried out in an attempt to confirm this point. Work is also continuing on a direct evaluation of the vapor pressure of uranium oxide as a function of $\mathrm{La}_{2} \mathrm{O}_{3}$ content and on an evaluation of the thermal conductivity of $\mathrm{U}_{3} \mathrm{O}_{8}$ with 53 mole per cent $\mathrm{La}_{2} \mathrm{O}_{3}$. The study of reactions at high temperatures and high pressures was temporarily discontinued so that certain ideas which were rnade available by the release of previously classijied General Electric Company information could be incorporated in the Battelle apparatus. These modifications will improve the Battelle "girdle" apparatus. Recalibratious have been completed and the study of reactions between $\mathrm{UO}_{2}$ and $\mathrm{MgO}$ and $\mathrm{Sc}_{2} \mathrm{O}_{3}$ will be continued.

'The irradiation of Type 347 stainless in the ETR is continuing, and exposures as high a:; $5.47 \times 10^{21} \mathrm{nvt}$ have been obtained. Two gamma-heat capsules are being exposed in the WTR. Thermocouple readings indicate that the top capsule is operating at 315 to $405 \mathrm{~F}$, which is in the range calculated for the 40 -megawatt power level of the reactor. The WTR will increase to 60 megawatts in the next few weeks, and it is believed that the gaminct-heat capsules will operate in the $600 \mathrm{~F}$ temperature range.

Corrosion testing of a group of niobium-base alloys in 600 and $680 \mathrm{~F}$ water is being continued. After total exposures ranging up to 364 days, the data continue to indicate that the birary containing $45 \mathrm{a} / 0$ zirconium and the ternary containing $28 \mathrm{a} / \mathrm{o}$ titanium and 6 a/o chromium are the most resistant alloys. However, a binary alloy containing 12.5 a/o vanadium appears to possess the optimum combination of high strength, low neutro: absorption, and promising corrosion resistance. Data from other alloys continue $t$, indicate that interstitials of carbon and oxygen do not affect corrosion resistance.

Construction of the mechanism for in-pile creep tests of Zircaloy-2 is progressing with insertion in the WTR scheduled for early June, 1960. Additional tensile tests are 
planned to investigate the presence of a yield point as related to the aging temperature and heat-treated condition of the test material, and internal-friction measurements will be continued in order to relate the yield-point phenomenon with the diffusion of either solute or interstitial atoms to dislocation sites. No structural difference between annealed Zircaloy -2 and Zircaloy -2 exhibiting a yield point has been noted by either light microscopy at magnifications of 250 diameters or by electron microscopy at magnifications of 35,000 diameters.

The development of techniques for the determination of oxygen in sodium at concentrations below $10 \mathrm{ppm}$ is continuing. Because results of previous tests have indicated that a surface layer of $\mathrm{MoO}_{2}$ on contacting surfaces reduces friction and area in sodium, an attempt is being made to test the effect of a layer of this material on the friction properties of stainless steel. Metallographically polished stainless steel flat surfaces have been coated with $\mathrm{MoO}_{2}$ by vacuum deposition, and these will be tested in sodium. Baseline friction data are currently being obtained for pairs of tool steel, and pairs of stainless steel, and for a Type 347 stainless steel flat and a molybdenum ball. These tests will be run dry and in molten sodium. 


\section{Valence Effects of Oxide Additions to Uranium Dioxide}

W. B. Wilson and C. M. Schwartz

Solid-state studies of uranium oxide containing varying a mounts of divalent and trivalent oxide additions are being continued. Exposure of undoped $\mathrm{UO}_{2}$ to air at elevated temperatures results in the formation of $\mathrm{U}_{3} \mathrm{O}_{8}$ with an as sociated disruptive volume change of nearly 30 per cent. In addition, the $\mathrm{U}_{3} \mathrm{O}_{8}$ so formed is relatively volatile at temperatures above $1000 \mathrm{C}$. Stabilization of the fluorite structure of $\mathrm{UO}_{2}$ and reduced volatility can be achieved by appropriate additions of oxides, such as $\mathrm{Y}_{2} \mathrm{O}_{3}$ or $\mathrm{La}_{2} \mathrm{O}_{3}$. In previous work results have been reported for the $\mathrm{UO}_{2}-\mathrm{La}_{2} \mathrm{O}_{3}$ and for the $\mathrm{UO}_{2}-\mathrm{Y}_{2} \mathrm{O}_{3}$ systems. These solid solutions, formed in va.cuo, have been investigated using chemical, structural, and electrical analyses. These results were subsequently correlated to the stability of the solid solutions after firing in air at temperatures up to $1760 \mathrm{C}$ for periorls of $20 \mathrm{hr}$.

The lattice parameters of the $\mathrm{UO}_{2}-\mathrm{La}_{2} \mathrm{O}_{3}$ solid solutions were observed to increase from 5.47 A for $\mathrm{UO}_{2}$ to $5.64 \mathrm{~A}$ for $\mathrm{UO}_{2}$ with 54 mole per cent $\mathrm{La}_{2} \mathrm{O}_{3}$. Air oxidation of these solid solutions produced smaller lattice parameters. The observed parameters were not as small as the corresponding parameters given by Hund for $\mathrm{U}_{3} \mathrm{O}_{8}-\mathrm{La}_{2} \mathrm{O}_{3}$ solid solutions. * It was earlier postulated that the solid solutions had not oxidized completely, resulting in larger lattice parameters than those observed by Hund. These results have previcusly been given in BMI-1318.

In recent work a series of solid solutions of $\mathrm{U}_{3} \mathrm{O}_{8}$ (as $\mathrm{UO}_{2.67}$ ) containing 40, 50, and 60 mole per cent $\mathrm{La}_{2} \mathrm{O}_{3}$ was prepared for electrical studies. The lattice parameters, however, were again observed to be larger than those reported by Hund for $\mathrm{U}_{3} \mathrm{O}_{2}-\mathrm{La}_{2} \mathrm{O}_{3}$ solutions. Moreover, the parameters were observed to follow Vegard's law extrapolated from subic $\mathrm{UO}_{2.67}$ to cubic $\mathrm{La}_{2} \mathrm{O}_{3}$, both of which are now known to exist. Thus the parameters obtained by the direct solid-state reactions in air of $\mathrm{U}_{3} \mathrm{O}_{8}$ with $\mathrm{La}_{2} \mathrm{O}_{3}$ were larger than those reported by Hund for $\mathrm{U}_{3} \mathrm{O}_{8}-\mathrm{La}_{2} \mathrm{O}_{3}$ prepared by evaporation of the nitrate solution and firing to the oxide.

These results at present strongly suggest that the Hund data do not represent $\mathrm{U}_{3} \mathrm{O}_{8}-\mathrm{La}_{2} \mathrm{O}_{3}$ solid solutions but actually describe solid solutions of $\mathrm{UO}_{3}-\mathrm{La}_{2} \mathrm{O}_{3}$, the smaller lattice parameters resulting from the additional oxidation. Moreover, the "ideal cation-anion lattice" determined by Hund on the basis of density considerations appeaj's to be that represented by the reaction:

$$
\mathrm{UO}_{3}+\mathrm{R}_{2} \mathrm{O}_{3} \rightarrow 3 \mathrm{RO}_{2} \text { (stoichiometric). }
$$

This result, which was not anticipated, indicates that the $\mathrm{U}_{3} \mathrm{O}_{8}-\mathrm{La}_{2} \mathrm{O}_{3}$ solid solutions prepared in the present work are not equivalent to the Hund solid solutions, and the 50 mo'le per cent $\mathrm{U}_{3} \mathrm{O}_{8}$ probably does not correspond to the stoichiometric oxide as given above.

"Hund, Von F., and Peetz, V., "Untersuchungen der Systeme $\mathrm{La}_{2} \mathrm{O}_{3}, \mathrm{Nd}_{2} \mathrm{O}_{3}, \mathrm{Sm}_{2} \mathrm{O}_{3}, \mathrm{Yb}_{2} \mathrm{O}_{3}, \mathrm{Sc}_{2} \mathrm{O}_{3}$ mit $\mathrm{U}_{3} \mathrm{O}_{8}$ ", Z. anorg. w. allgem. Chem., 271, $6(1952-53)$. 
In order to confirm the above hypothesis, microbalance analyses of the $\mathrm{U}_{3} \mathrm{O}_{8}-\mathrm{La}_{2} \mathrm{O}_{3}$ solid solutions will be carried out. Work is also continuing on a direct evaluation of the vapor pressure of uranium oxide as a function of $\mathrm{La}_{2} \mathrm{O}_{3}$ content, and evaluation of the thermal conductivity of $\mathrm{U}_{3} \mathrm{O}_{8}$ with 53 mole per cent $\mathrm{La}_{2} \mathrm{O}_{3}$.

\section{High-Pressure High-Temperature Solid-State Studies}

W. B. Wilson and C. M. Schwartz

An investigation is being conducted to determine the effects of ultrahigh pressure and high temperature on the uranium-oxygen system and on the reaction of uranium oxide with various mixed oxides. The major aspects of previous research on this program have led to the development of high-pressure equipment and techniques and to the determination of the effects of combined ultrahigh pressure and high temperature on the oxides of uranium.

It was contemplated that research on the study of reactions would continue during the month. However, release of the classified information of the General Electric Company with respect to the "Belt" apparatus has permitted the adoption of certain techniques to the Battelle "Girdle" device. Both the Battelle Girdle device and the G. E. Belt apparatus utilize conical pistons in conjunction with a central binding ring in which the high pressure is produced. Thus, the existing girdle apparatus may be simply converted to the Belt by modification of the central insert.

Experimental work was undertaken during the month to increase the use of the "compressible gasket" effect in the high-pressure apparatus. The change permits an increase in sample height and allows adoption of a thermal insulator at the ends of the heater, thereby providing significant reduction in thermal gradients, which have proved to be a major difficulty. These modifications required that the apparatus be recalibrated for pressure and temperature.

The pressure recalibration has been completed and the Girdle apparatus was tested to failure. The transitions in bismuth and barium were detected, including the bismuth transition at 121,000 . The device failed by rupture of the central insert at a pressure of 135,000 after having been cycled to 100,000 six times. The recalibration was the same as that determined previously.

As an additional means of calibration the synthesis of diamond was undertaken. Diamond was observed to transform from graphite, using molten nickel as a catalyst, at a pressure of $100,000 \mathrm{~atm}$ at about $1600 \mathrm{C}$. Repeated experiments at 75,000 at the same temperature failed to produce the transformation.

Work was initiated to convert the existing equipment to the Belt configuration for a direct comparison of capabilities. In addition, modification to the Battelle Girdle configuration were undertaken to obtain improved die efficiency and larger sample sizes. Such modifications do not alter the pressure equipment, but represent changes in the expendable pistons and the central insert of the apparatus. 
Work will continue on the study of the effect of pressure on the reaction of uran:um oxide with other oxides. Emphasis will be placed on reactions between $\mathrm{UO}_{2}$ and $\mathrm{lgO}$ and $\mathrm{Sc}_{2} \mathrm{O}_{3}$, since previous work indicated possible pressure effects were prodinced.

$\underline{\text { Irradiation-Surveillance Program on Type } 347 \text { Stainless Stee1 }}$

W. E. Murr, F. R. Shober, R. L. Ritzman, and J. F. Lagedrost

The objective of the stainless steel surveillance program is to determine the mechanical-property changes that occur in Type 347 stainless steel as a result of bombardment by fast neutrons (neutrons with energies above $1 \mathrm{Mev}$ ). Subsize tensile and impa:t specimens of this material will be subjected to mechanical tests after they have been exposed to dosages of 0.5 to $1.5 \times 10^{22}$ nvt, and the results obtained will be comparec. with the mechanical properties of unirradiated material. The information will be used primarily for a periodic evaluation of the effect of irradiation damage occurring to the KAPL C-33 loop, which is being operated in the ETR.

Currently, 11 capsules are undergoing j.rradiation in the ETR. Three capsules have been in-pile since August, 1959, and eight capsules have been in-pile since June', 1958. The group of three will be given postirradiation heat treatments prior to mechanical testing, while the additional eight capsules will be tested without further heat treatinent. A third group of capsules is being irradiated in the Westinghouse Testing Reacior (WTR). These capsules have been designed to operate at specimen-surface temperatures of about $600 \mathrm{~F}$ through gamma heating of specimens and capsule components.

The total estimated exposures for the 11 . ETR capsules as of the end of ETR Cycle 26 (February 15) are reported in Table A-1. The exposure values are based on ETR quoted fluxes from the region of the surveillance capsules, and will be subject to revision at the end $0:$ a current neutron-flux survey.

Two gamma -heat capsules, BMI-24-15 and BMI-24-19, began their in-pile exposure in the Westinghouse Test Reactor on February 23, 1960. This first cycle, which was intenced primarily as a 20 to 40-megawatt pover escallation, terminated about March 13 after accumulating a total of $690 \mathrm{MWD}$ at an average power level of around 35 megawatts. Temperatures obtained from thermocouples adjacent to test specimens at 40-megawatt operation ranged from 315 to $405 \mathrm{~F}$, the temperature variation being caused primarily by changes in rate of coolant-water flow and control-rod position. Calculated temperatures for tha second capsule, which is directly below the lead capsule, are based on the quoted gamma flux profile and the capsule's relative vertical position compared with BMI-24-19. The estimated temperature data ranged from $350 \mathrm{~F}$ at the top to $250 \mathrm{~F}$ at the bottom at 40-m gawatt reactor operation and $9500-\mathrm{gpm}$ coolant flow rate.

The next WTR reactor cycle will be a 40-to-60-megawatt power escallation, which is scheduled to run for 8 days, beginning March 27, The reactor will operate during April and will start routine 60 -megawatt operation about May 8 . 
TABLE A-1. CAPSULES PREPARED FOR THE TYPE 347 ST AINLESS STEEL IRRADIATION SURVEILLANCE PROGRAM

\begin{tabular}{|c|c|c|c|c|c|c|c|c|}
\hline \multirow[b]{2}{*}{ Capsule } & \multirow{2}{*}{$\begin{array}{l}\text { Type of Specimens } \\
\text { in Capsules }\end{array}$} & \multirow{2}{*}{$\begin{array}{c}\text { Proposed } \\
\text { Irradiation } \\
\text { Temperature, } \\
\text { F } \\
\end{array}$} & \multirow{2}{*}{$\begin{array}{c}\text { Approximate } \\
\text { Removal } \\
\text { Date (a) } \\
\end{array}$} & \multirow{2}{*}{$\begin{array}{c}\text { Approximate } \\
\text { Exposure } \\
\text { at Time of } \\
\text { Removal }^{(b)} \text {, nvt }\end{array}$} & \multicolumn{2}{|c|}{$\begin{array}{l}\text { Total Exposure as of } \\
\text { February } 15,1960, \mathrm{nvt}\end{array}$} & \multirow[b]{2}{*}{ Location } & \multirow[b]{2}{*}{ Remarks } \\
\hline & & & & & Top & Bottom & & \\
\hline BMI-24-1 & Tensile and fatigue & 600 & January, 1959 & $1.55 \times 10^{20}$ & $\cdots$ & -- & BMI & $\begin{array}{l}\text { Examined at BMI Hot-Cell } \\
\text { Facility for melting }\end{array}$ \\
\hline BMI $-24-2$ & Tensile and fatigue & 120 & January, 1962 & $1.31 \times 10^{22}$ & $4.018 \times 10^{21}$ & $4.764 \times 10^{21}$ & $\begin{array}{l}\text { ETR } \\
\mathrm{K}-8-\mathrm{NE}\end{array}$ & Being irradiated \\
\hline BMI-24-3 & Tensile and fatigue & 600 & -- & -- & -- & -- & BMI & To be irradiated in the WTR \\
\hline BMI-24-4 & Tensile and fatigue & 120 & January, 1963 & $1.78 \times 10^{22}$ & $3.167 \times 10^{21}$ & $4.481 \times 10^{21}$ & $\begin{array}{l}\text { ETR } \\
\mathrm{K}-8-\mathrm{SE}\end{array}$ & Being irradiated \\
\hline BMI-24-5 & Tensile and fatigue & 600 & -- & -- & -- & -- & BMI & To be irradiated in the WTR \\
\hline BMI-24-6 & Tensile and fatigue & 120 & June, 1961 & $1.08 \times 10^{22}$ & $4.981 \times 10^{21}$ & $3.948 \times 10^{21}$ & $\begin{array}{l}\text { ETR } \\
\mathrm{K}-8-\mathrm{NE}\end{array}$ & Being irradiated \\
\hline BMI-24-7 & Tensile and fatigue & 600 & -- & -- & -- & - & $\mathrm{BMI}$ & To be irradiated in the WTR \\
\hline BMI-24-8 & Tensile and fatigue & 120 & June, 1962 & $1.54 \times 10^{22}$ & $3.481 \times 10^{21}$ & $4.461 \times 10^{21}$ & $\begin{array}{l}\text { ETR } \\
\text { K-8-SE }\end{array}$ & Being irradiated \\
\hline BMI-24-9 & Tensile and fatigue & 600 & -- & -- & -- & - & BMI & To be irradiated in the WTR \\
\hline BMI-24-10 & Tensile and fatigue & 120 & January, 1961 & $0.84 \times 10^{22}$ & $4.334 \times 10^{21}$ & $4.085 \times 10^{21}$ & $\begin{array}{l}\text { ETR } \\
\text { K-8-SE }\end{array}$ & Being irradiated \\
\hline BMI-24-11 (c) & Tensile and fatigue & 600 & -- & -- & -- & -- & BMI & Damaged at the ETR \\
\hline BMI-24-12 & Tensile and fatigue & 120 & June, 1960 & $0.61 \times 10^{22}$ & $5.474 \times 10^{21}$ & $4.934 \times 10^{21}$ & $\begin{array}{l}\text { ETR } \\
\text { L-8-SE }\end{array}$ & Being irradiated \\
\hline BMI-24-13 & Impact & 600 & -- & -- & -- & -- & BMI & To be irradiated in the WTR \\
\hline BMI-24-14 & Impact & 120 & June, 1962 & $1.54 \times 10^{22}$ & $4.673 \times 10^{21}$ & $4.748 \times 10^{21}$ & $\begin{array}{l}\text { ETR } \\
\mathrm{K}-8-\mathrm{NW}\end{array}$ & Being irradiated \\
\hline
\end{tabular}


TABLE A-1. (Continued)

\begin{tabular}{|c|c|c|c|c|c|c|c|c|}
\hline \multirow[b]{2}{*}{ Capsule } & \multirow{2}{*}{$\begin{array}{c}\text { Type of Specimens } \\
\text { in Capsules }\end{array}$} & \multirow{2}{*}{$\begin{array}{l}\text { Proposed } \\
\text { Irradiation } \\
\text { Temperature, } \\
\text { F }\end{array}$} & \multirow{2}{*}{$\begin{array}{l}\text { Approximate } \\
\text { Removal } \\
\text { Date(a) } \\
\end{array}$} & \multirow{2}{*}{$\begin{array}{c}\text { Approximate } \\
\text { Exposure } \\
\text { at Time of } \\
\text { Removal(b), nvt }\end{array}$} & \multicolumn{2}{|c|}{$\begin{array}{l}\text { Total Exposure as of } \\
\text { F ebruary } 15,1960, \text { nvt }\end{array}$} & \multirow[b]{2}{*}{ Location } & \multirow[b]{2}{*}{ Remarks } \\
\hline & & & & & Top & Bottom & & \\
\hline \multirow{2}{*}{ BMI-24-15 } & Impact & 600 & -- & -- & -- & -- & WTR & \\
\hline & & & & & & & $L-7-6$ & To be irradiated in the WTR \\
\hline BMI-24-16 & Impact & 120 & June, 1960 & $0.61 \times 10^{22}$ & $4.721 \times 10^{21}$ & $4.125 \times 10^{21}$ & $\begin{array}{l}\text { ETR } \\
K-8-N W\end{array}$ & Being irradiated \\
\hline BMI-24-17(c) & Tensile and fatigue & 600 & October, 1958 & $3.25 \times 10^{20}$ & -- & -- & BMI & $\begin{array}{l}\text { Examined at BMI Hot-Cell } \\
\text { Facility after high tempera- } \\
\text { ture observed }\end{array}$ \\
\hline \multirow[t]{2}{*}{ BMI-24-18 } & Tensile and fatigue & 120 & -- & -- & $9.23 \times 10^{20}$ & $1.452 \times 10^{21}$ & ETR & \\
\hline & & & & & & & $\mathrm{K}-8-\mathrm{NW}$ & $\begin{array}{l}\text { Being irradiated for postirradia- } \\
\text { tion annealing studies }\end{array}$ \\
\hline \multirow[t]{2}{*}{ BMI-24-19(c) } & Tensile and fatigue. & 600 & - & -- & -- & -- & WTR & \\
\hline & & & & & & & $L-7-6$ & $\begin{array}{l}\text { Fabricated to replace BMI-24- } \\
\text { 17; to be irradiated in the } \\
\text { WTR }\end{array}$ \\
\hline \multirow[t]{2}{*}{ BMI-24-20 } & Tensile and fatigue & 120 & - & - & $1.048 \times 10^{21}$ & $1.552 \times 10^{21}$ & ETR & \\
\hline & . & & & & & & $K-8-N E$ & $\begin{array}{l}\text { Being irradiated for postirradia- } \\
\text { tion annealing studies }\end{array}$ \\
\hline BMI-24-21 & Tensile and fatigue & 600 & -- & -- & -- & - & BMI & $\begin{array}{l}\text { Fabricated to replace BMI-24- } \\
1 \text {; to be irradiated in the } \\
\text { WTR }\end{array}$ \\
\hline \multirow[t]{2}{*}{ BMI-24-22 } & Tensile and fatigue & 120 & -- & -- & $1.352 \times 10^{21}$ & $1.803 \times 10^{21}$ & ETR & \\
\hline & & & & & & & L-8-SE & $\begin{array}{l}\text { Being irradiated for postirradia- } \\
\text { tion annealing studies }\end{array}$ \\
\hline
\end{tabular}

(a) Based on 6-month lead on loop, plus 2 months for examination.

(b) Based on maximum fast flux at tube of $1.7 \times 10^{14} \mathrm{nv}$ for 6 -month periods.

(c) Thermocouple lead capsule. 


\title{
Development of Corrosion-Resistant Niobium Alloys
}

\author{
D. J. Maykuth, W. D. Klopp, R. I. Jaffee, \\ W. E. Berry, and F. W. Fink
}

Corrosion studies are being continued in the program to develop a high-strength, low-cross-section, corrosion-resistant niobium alloy for pressurized-water applications. Mechanical-property evaluations have been completed. A report on all phases of the program is now in the rough draft form.

Additional exposures of 14 to 28 days to 600 and $680 \mathrm{~F}$ water and $750 \mathrm{~F}$ steam have been obtained during March. A summary of the cumulative weight changes obtained to date is presented in Table A-2. After exposure times ranging up to 364 days, the data continue to indicate that the most resistant alloys are those containing about 45 a/o zirconium and a ternary containing 28 a/o titanium-6 a/o chromium. These alloys exhibit tightly adherent films and low weight gains. However, a 12.5 a/o vanadium binary alloy possesses the optimum combination of high strength, low neutron absorption, and promising corrosion resistance.

Data for vanadium-zirconium and vanadium-titanium alloys containing carbon and oxygen additions, for increased strength, continue to indicate that the interstitials do not affect the corrosion resistance of these alloys. This confirms earlier observations that alloys prepared from commercial-purity niobium (high in interstitials) were as corrosion resistant as those prepared from high-purity niobium (low in interstitials).

Corrosion tests will be continued on the alloys described in Table A-2.

Investigation of the Creep Properties of Zircaloy-2 During Irradiation at Elevated Temperatures

F. R. Shober, P. B. Shumaker, A. P. Young, and M. F. Amateau

Changes in creep properties of Zircaloy-2 at 650, as reflected by comparison of the results of in-reactor and out-of-reactor creep tests, are being investigated. Evidence of strain aging in Zircaloy-2 and its related mechanisms are also being investigated. Strain aging, if occurring during creep, can influence appreciably the creep properties of a material. The major part of these strain-aging studies consists of tensile tests, internal-friction studies, and electron microscopy of thin films.

The design of a capsule to contain the creep specimen and auxiliary components during irradiation has been completed, and construction of various components has been started. As designed, the capsule will contain two identical sheet-type test specimens back to back, one to sustain the load, and the other to provide geometrical symmetry for heat transfer. These specimens are designed to have three separate gage sections with respective widths to produce an individual tensile stress in each section. External 
TABLE A-2. SUMMARY OF CORROSION RESULTS OBTAINED ON NIOBIUM ALLOYS EXPOSED TO HIGH-TEMPERATURE WATER AND STEAM

\begin{tabular}{|c|c|c|c|c|c|c|c|}
\hline \multirow[b]{2}{*}{$\begin{array}{c}\text { Al oy Addition } \\
\text { (Balaise Niobium), } \\
\text { a/o }\end{array}$} & \multirow[b]{2}{*}{. } & \multicolumn{2}{|c|}{$600 \mathrm{~F} \mathrm{Water}$} & \multicolumn{2}{|c|}{$680 \mathrm{~F}$ Water } & \multicolumn{2}{|c|}{$750 \mathrm{~F}$ Steam } \\
\hline & & $\begin{array}{c}\text { Exposure } \\
\text { Time, } \\
\text { days }\end{array}$ & $\begin{array}{c}\text { Total } \\
\text { Weight } \\
\text { Change, } \\
\text { mg per } \mathrm{cm}^{2}\end{array}$ & $\begin{array}{c}\text { Exposure } \\
\text { Time, } \\
\text { days }\end{array}$ & $\begin{array}{c}\text { Total } \\
\text { Weight } \\
\text { Change, } \\
\text { mg per } \mathrm{cm}^{2} \\
\end{array}$ & $\begin{array}{c}\text { Exposure } \\
\text { Time, } \\
\text { days }\end{array}$ & $\begin{array}{c}\text { Total } \\
\text { Weight } \\
\text { Change, } \\
\text { mg per } \mathrm{cm}^{2}\end{array}$ \\
\hline \multicolumn{8}{|c|}{ Commercial Niobium, Rocking-Hearth Melts } \\
\hline Unallc yed $\mathrm{Nb}$ & & 364 & -85.3 & $42(a)$ & Disintegrated & $28(a)$ & Disintegrated \\
\hline $10.5 Z, r$ & & -- & -- & $196^{(a)}$ & 0.67 & 224 & -43.8 \\
\hline $26.1 \mathrm{Z}, \mathrm{r}$ & & -- & -- & $196^{(a)}$ & 0.07 & -- & -- \\
\hline $35.7 \bar{Z} \mathbf{r}$ & & -- & -. & $196^{(a)}$ & 0.66 & -- & - \\
\hline $45.72 . r$ & & - & -- & $196(a)$ & 0.55 & -- & -- \\
\hline $1.08 \mathrm{VI}$ & & $\ldots$ & -- & $196(a)$ & -2.60 & 224 & -113.0 \\
\hline $4.67 \mathrm{~V}^{\prime}$ & & -. & -- & 196 (a) & -29.3 & -- & -- \\
\hline $9.56 \mathrm{vr}^{r}$ & & - & - & $196^{(a)}$ & Cracked & -- & - \\
\hline $2.45 \mathrm{Mlo}$ & \multirow{3}{*}{ 霖 } & -. & - & $196^{(a)}$ & -7.10 & 98 & Disintegrated \\
\hline $5.20 \mathrm{Mlo}$ & & - & -- & $196^{(a)}$ & -1.30 & 224 & -201.5 \\
\hline $7.40 \times 10$ & & - & - & $196^{(a)}$ & 0.62 & -- & - \\
\hline $4.42 \mathrm{~V}$ & & - & -- & $196(a)$ & 0.42 & 224 & -28.3 \\
\hline $6.59 \mathrm{~V}$ & & -. & - & $196(a)$ & 0.73 & 224 & 1.30 \\
\hline $8.93 \mathrm{~V}$ & & - & -- & $196^{(a)}$ & 0.59 & 224 & 1.21 \\
\hline $10.7 \mathrm{~V}$ & & -- & - & $196^{(a)}$ & 0.78 & -- & -- \\
\hline $13.7 \mathrm{~V}$ & & -- & - & $196^{(a)}$ & 0.50 & - & -- \\
\hline $24.2 \mathrm{~V}$ & & - & -- & $196^{(a)}$ & 0 & -- & -- \\
\hline $4.90 \mathrm{~F} z$ & & -- & -- & $196^{(a)}$ & 0.10 & 98 & Disintegrated \\
\hline $9.41 \mathrm{Ti}$ & & $-\infty$ & $\cdots$ & $196^{(a)}$ & 0.65 & 224 & 1.12 \\
\hline $18.8 \mathrm{Ti}$ & & -. & - & $196(a)$ & 0.48 & -- & -- \\
\hline $24.3 \mathrm{Ti}$ & & -- & -- & $196^{(a)}$ & 0.52 & -- & - \\
\hline $30.5 \mathrm{Ti}$ & & -- & - & $196^{(a)}$ & 0.40 & - & - \\
\hline $33.8 \mathrm{Ti}$ & & $\cdots$ & - & $196^{(a)}$ & 0.33 & - & -- \\
\hline $12.0 \mathrm{Ti}-0.5 \mathrm{Cr}$ & & -. & -- & $196^{(a)}$ & 0.66 & -- & - \\
\hline $20.2 \mathrm{Tl}-2.1 \mathrm{Cr}$ & & -- & -- & $196^{(a)}$ & 0.39 & -- & -- \\
\hline $28.2 \mathrm{Tl}-6.1 \mathrm{Cr}$ & & -- & -- & $196^{(a)}$ & 0.20 & $-\cdots$ & -- \\
\hline $12.0 \mathrm{~T}-4.2 \mathrm{Mo}$ & &.- & -- & $196(a)$ & 0.64 & -- & - \\
\hline $17.4 \mathrm{~T}:-6.2 \mathrm{Mo}$ & & -- & - & $196^{(a)}$ & 0.54 & -- & - \\
\hline $23.1 \mathrm{~T}:-7.8 \mathrm{Mo}$ & & -- & - & $196^{(a)}$ & 0.45 & -- & -- \\
\hline $10.4 \mathrm{~T}-5.0 \mathrm{~V}$ & & -- & -- & $196(a)$ & 0.56 & -- & -- \\
\hline $16.1 \mathrm{~T}-8.4 \mathrm{~V}$ & & -- & -- & $196^{(a)}$ & 0.40 & $\ldots$ & -- \\
\hline $22.6 \mathrm{~T}-11.0 \mathrm{~V}$ & & - & -- & $196(a)$ & 0.48 & -- & -- \\
\hline \multicolumn{8}{|c|}{ High-Purity Niobium, Consumable-Electrode Melts } \\
\hline Unalloyed $\mathrm{Nb}$ & & 364 & 0.51 & 336 & -7.50 & $224^{(a)}$ & -54.0 \\
\hline $7.18 \mathrm{M}$ & & 364 & 0.71 & $252^{(a)}$ & Cracked & $70^{(a)}$ & Cracked \\
\hline $12.5 \mathrm{~V}$ & & 364 & 0.40 & 336 & 0.72 & 308 & 0.84 \\
\hline
\end{tabular}


TABLE A-2. (Continued)

\begin{tabular}{|c|c|c|c|c|c|c|}
\hline \multirow[b]{2}{*}{$\begin{array}{c}\text { Alloy Addition } \\
\text { (Balance Niobium), } \\
\text { a/o }\end{array}$} & \multicolumn{2}{|c|}{$600 \mathrm{~F}$ Water } & \multicolumn{2}{|c|}{$680 \mathrm{~F}$ Water } & \multicolumn{2}{|c|}{750 F Steam } \\
\hline & $\begin{array}{l}\text { Exposure } \\
\text { Time, } \\
\text { days }\end{array}$ & $\begin{array}{c}\text { Total } \\
\text { Weight } \\
\text { Change, } \\
\text { mg per } \mathrm{cm}^{2}\end{array}$ & $\begin{array}{c}\text { Exposure } \\
\text { Time, } \\
\text { days }\end{array}$ & $\begin{array}{c}\text { Total } \\
\text { Weight } \\
\text { Change, } \\
\text { mg per } \mathrm{cm}^{2}\end{array}$ & $\begin{array}{c}\text { Exposure } \\
\text { Time, } \\
\text { days }\end{array}$ & $\begin{array}{c}\text { Total } \\
\text { Weight } \\
\text { Change, } \\
\text { mg per } \mathrm{cm}^{2}\end{array}$ \\
\hline \multicolumn{7}{|c|}{ High-Purity Niobium, Consumable-Electrode Melts (Continued) } \\
\hline $46.8 \mathrm{Zr}-5.06 \mathrm{Ti}$ & 336 & 0.26 & 308 & 1.04 & 280 & 2.54 \\
\hline $11.2 \mathrm{Ti}-3.2 \mathrm{Mo}$ & 336 & 0.25 & 308 & 0.64 & 280 & $0.38^{(b)}$ \\
\hline $18.8 \mathrm{Ti}-8.7 \mathrm{Mo}$ & 336 & 0.38 & 308 & 0.68 & 280 & 0.55 \\
\hline $9.9 \mathrm{Zr}-9.4 \mathrm{~V}$ & 252 & $0.09^{(b)}$ & 224 & $0.13^{(b)}$ & 196 & -6.32 \\
\hline $5.7 \mathrm{Zr}-11.4 \mathrm{~V}$ & 252 & $0.06^{(b)}$ & 224 & 0.47 & 196 & -2.37 \\
\hline $9.1 \mathrm{Ti}-6.3 \mathrm{Cr}$ & 252 & -0.02 & 224 & 0.53 & 196 & -5.53 \\
\hline $7.5 \mathrm{~V}$ & 70 & 0.29 & 56 & 0.41 & 70 & 1.26 \\
\hline $7.5 \mathrm{~V}-0.19 \mathrm{~N}$ & 70 & 0.23 & 56 & 0.43 & 70 & 0.54 \\
\hline $7.5 \mathrm{~V}-2.5 \mathrm{Ti}$ & 70 & 0.25 & 56 & 0.50 & 70 & 0.52 \\
\hline $7.5 \mathrm{~V}-2.5 \mathrm{Mo}$ & 70 & 0.29 & 56 & 0.48 & 70 & 0.74 \\
\hline
\end{tabular}

High-Purity Niobium, Rocking-Hearth Melts

Unalloyed $\mathrm{Nb}$ Unalloyed $\mathrm{Nb}$ Unalloyed $\mathrm{Nb}$

$1.1 \mathrm{Zr}$

$2.2 \mathrm{Zr}$

$5 \mathrm{Zr}$

$10.2 \mathrm{Zr}$

$40 \mathrm{Zr}$

$65 \mathrm{Zr}$

$75 \mathrm{Zr}$

$90 \mathrm{Zr}$

$3.2 \mathrm{Ti}$

$10.5 \mathrm{Ti}$

$25.0 \mathrm{Ti}$

$<0.02 \mathrm{Cr}$

$0.5 \mathrm{Cr}$

$0.5 \mathrm{Cr}$

$<0.08 \mathrm{Fe}$

$0.3 \mathrm{Fe}$

$10 \mathrm{Fe}$

$10.9 \mathrm{Zr}-5.1 \mathrm{Ti}$

$25 \mathrm{Zr}-5 \mathrm{Ti}$

$25 \mathrm{Zr}-15 \mathrm{Ti}$

$25 \mathrm{Zr}-25 \mathrm{Ti}$

$\begin{array}{lll}-. & -- & 252 \\ -- & -- & 84(\mathrm{a}) \\ -- & -- & 224 \\ & & 168(\mathrm{a}) \\ -- & -- & 140 \\ -- & -- & 224 \\ -- & -- & 224 \\ -- & -- & 224 \\ -- & -- & 224 \\ -- & -- & \\ & & 224\end{array}$

$\begin{array}{lll}- & - & 224 \\ -- & -- & 224\end{array}$

$\begin{array}{lll}-- & -- & 252\end{array}$

$\begin{array}{lll}-- & - & 252\end{array}$

$\begin{array}{lll}-- & - & 252\end{array}$

$\begin{array}{lll}-- & - & 252\end{array}$

$\begin{array}{lll}-- & -- & 252\end{array}$

$\begin{array}{lll}-- & -- & 224\end{array}$

$\begin{array}{lll}- & - & 224\end{array}$

-- $\quad--\quad 140$

$--\quad--\quad 28^{(a)}$

$\begin{array}{lll}-- & -- & 224\end{array}$

$\begin{array}{lll}-- & -- & 224\end{array}$

-- 20.

$\begin{array}{lll}- & - & \end{array}$
$-6.13$

Disintegrated

$-1.00$

Disintegrated

$-21.5$

$-17.5$

$-0.05$

0.86

$-1.22$

(edge cracks)

1.69

1.62

$-12.4$

0.74

0.45

$-5.09$

$-1.82$

$-6.13$

$-2.04$

$-12.1$

Cracked
0.62
$-0.25$
0.46
0.51

-- 
TABLE A-2. (Continued)

\begin{tabular}{|c|c|c|c|c|c|c|}
\hline \multirow[b]{2}{*}{$\begin{array}{c}\text { Alloy Addition } \\
\text { (Bal ance Niobium), } \\
\text { a/o } \\
\end{array}$} & \multicolumn{2}{|c|}{$600 \mathrm{~F}$ Water } & \multicolumn{2}{|c|}{$680 \mathrm{~F}$ Water } & \multicolumn{2}{|c|}{$750 \mathrm{~F}$ Steam } \\
\hline & $\begin{array}{c}\text { Exposure } \\
\text { Time, } \\
\text { days }\end{array}$ & $\begin{array}{c}\text { Total } \\
\text { Weight } \\
\text { Change. } \\
\text { mg per } \mathrm{cm}^{2} \\
\end{array}$ & $\begin{array}{c}\text { Exposure } \\
\text { Time, } \\
\text { days }\end{array}$ & $\begin{array}{c}\text { Total } \\
\text { Weight } \\
\text { Change, } \\
\text { mg per } \mathrm{cm}^{2} \\
\end{array}$ & $\begin{array}{c}\text { Exposure } \\
\text { Time, } \\
\text { days }\end{array}$ & $\begin{array}{c}\text { Total } \\
\text { Weight } \\
\text { Change, } \\
\text { mg per } \mathrm{cm}^{2} \\
\end{array}$ \\
\hline \multicolumn{7}{|c|}{ High-Purity Niobium, Rocking-Hearth Melts (Continued) } \\
\hline $35 \mathrm{Z}:-5 \mathrm{Ti}$ & -- & -- & 224 & 0.74 & -- & - \\
\hline $35 \mathrm{Z}:-15 \mathrm{Ti}$ & -- & -- & 224 & 0.22 & -- & -- \\
\hline $45 \mathrm{Z}:-5 \mathrm{Ti}$ & -- & -- & 224 & 0.79 & -- & -- \\
\hline $10 \mathrm{Z}-5 \mathrm{Mo}$ & -- & -- & 224 & 0.16 & -- & - \\
\hline $35 \mathrm{Z}-5 \mathrm{Mo}$ & -- & -- & 224 & 0.58 & -- & -- \\
\hline $45 \mathrm{Z}-5 \mathrm{Mo}$ & -- & -- & 224 & 0.74 & -- & -- \\
\hline $35 \mathrm{Z}-5 \mathrm{Al}$ & -- & -- & 224 & 0.26 & -- & -- \\
\hline $4 \dot{5} \mathrm{Z}:-5 \mathrm{Al}$ & -- & -- & 224 & 0.64 & -- & -- \\
\hline $10 \mathrm{Z}-5 \mathrm{Cr}$ & -- & $\cdots$ & 224 & 0.45 & -- & -. \\
\hline $45 \mathrm{Z}-5 \mathrm{Cr}$ & -- & -- & 224 & 0.52 & -- & -- \\
\hline $10 \mathrm{Z}:-5 \mathrm{Fe}$ & -- & -- & 224 & 0.13 & -- & -- \\
\hline $2.5 Y$ & -- & -- & 252 & 1.09 & - & -- \\
\hline $2.0 \mathrm{~V}-2.5 \mathrm{Ti}$ & -- & -- & 224 & 0.91 & -- & -- \\
\hline $2.0 \mathrm{~V}-2.3 \mathrm{Mo}$ & -- & -- & 224 & 1.17 & -- & -- \\
\hline $2.2 \mathrm{~V}^{\prime}-0.54 \mathrm{Fe}$ & -- & -- & 224 & 0.45 & -- & -- \\
\hline $1.8 \mathrm{I}^{\prime}-<0.02 \mathrm{Cr}$ & -- & -- & 224 & 0.33 & -- & -- \\
\hline $1.8 \mathrm{~J}-0.14 \mathrm{Al}$ & -- & -- & 224 & 0.89 & -- & -- \\
\hline $2.5 \mathrm{~V}-2.5 \mathrm{Zr}$ & - & -- & 140 & -3.18 & -- & -- \\
\hline $2.2 \mathrm{~V}-0.87 \mathrm{Ni}$ & -- & -- & $28^{(a)}$ & $\begin{array}{l}-1.00 \\
\text { (cracked) }\end{array}$ & -- & -- \\
\hline $4.0 \mathrm{~V}-2.3 \mathrm{Zr}$ & -- & -- & 224 & 0.59 & -- & -- \\
\hline $5 \mathrm{~V}-\{5 \mathrm{Zr}$ & -- & -- & 224 & -2.77 & -- & -- \\
\hline $2.5 \mathrm{~V}-35 \mathrm{Zr}$ & -- & -- & 224 & -5.06 & -- & -- \\
\hline $5 \mathrm{~V}-45 \mathrm{Zr}$ & -- & -- & 224 & 0.63 & -- & -- \\
\hline $1 \mathrm{Ce}$ & $\cdots$ & -- & 84 & -7.40 & -- & -- \\
\hline $1 Y$ & -- & -- & 84 & -15.0 & -- & -- \\
\hline $5 \mathrm{Y}$ & -- & -- & 56 & -64.2 & -- & -- \\
\hline $1 \mathrm{Ni}$ & -- & -- & 56 & $0.27(b)$ & -- & -- \\
\hline $2.5 \mathrm{Ni}$ & - & -- & $7(\mathrm{a})$ & Broke, 7 days & - & -- \\
\hline $5 \mathrm{Ni}$ & -- & -- & $7^{(a)}$ & Disintegrated & -- & -- \\
\hline
\end{tabular}


TABLE A-2. (Continued)

\begin{tabular}{|c|c|c|c|c|c|c|}
\hline \multirow[b]{2}{*}{$\begin{array}{c}\text { Alloy Addition } \\
\text { (Balance Niobium), } \\
\text { a/o }\end{array}$} & \multicolumn{2}{|c|}{$600 \mathrm{~F} \mathrm{Water}$} & \multicolumn{2}{|c|}{$680 \mathrm{~F}$ Water } & \multicolumn{2}{|c|}{$750 \mathrm{~F}$ Steam } \\
\hline & $\begin{array}{l}\text { Exposure } \\
\text { Time, } \\
\text { days }\end{array}$ & $\begin{array}{c}\text { Total } \\
\text { Weight } \\
\text { Change, } \\
\text { mg per } \mathrm{cm}^{2}\end{array}$ & $\begin{array}{c}\text { Exposure } \\
\text { Time, } \\
\text { days }\end{array}$ & $\begin{array}{c}\text { Total } \\
\text { Weight } \\
\text { Change, } \\
\text { mg per } \mathrm{cm}^{2}\end{array}$ & $\begin{array}{c}\text { Exposure } \\
\text { Time, } \\
\text { days }\end{array}$ & $\begin{array}{c}\text { Total } \\
\text { Weight } \\
\text { Change, } \\
\text { mg per } \mathrm{cm}^{2}\end{array}$ \\
\hline \multicolumn{7}{|c|}{ High-Purity Niobium, Rocking-Hearth Melts (Continued) } \\
\hline $1 \mathrm{Pd}$ & -- & -- & 56 & $15.7^{(a)}$ & -- & - \\
\hline $5 \mathrm{~V}-2.5 \mathrm{Ti}$ & - & -- & 84 & 0.59 & -- & -- \\
\hline $5 \mathrm{~V}-2.5 \mathrm{Mo}$ & -- & $-\infty$ & 56 & 0.36 & -- & -- \\
\hline $5 \mathrm{~V}-2.5 \mathrm{Fe}$ & -- & -- & 56 & 0.31 & -- & -- \\
\hline $5 \mathrm{~V}-2.5 \mathrm{Cr}$ & -- & -- & 84 & 0.72 & - & -- \\
\hline $5 \mathrm{~V}-2.5 \mathrm{Al}$ & -- & -- & 84 & 0.69 & -- & -- \\
\hline $5 \mathrm{~V}-2.5 \mathrm{Ni}$ & -- & -- & 56 & 0.49 & -- & -- \\
\hline $2.5 \mathrm{~V}-0.5 \mathrm{C}$ & -- & - & 56 & 0.40 & - & - \\
\hline $5 \mathrm{~V}-0.5 \mathrm{C}$ & -- & -- & 56 & 0.30 & -- & -- \\
\hline $2.5 \mathrm{~V}-0.25 \mathrm{Ti}-0.5 \mathrm{O}$ & -- & -- & 56 & 0.19 & $\therefore$ & - \\
\hline $5 \mathrm{~V}-0.25 \mathrm{Ti}-0.5 \mathrm{O}$ & -- & -- & 56 & 0.27 & -- & -- \\
\hline $2.5 \mathrm{~V}-0.25 \mathrm{Zr}-0.50$ & -- & -- & 56 & 0.33 & -- & -- \\
\hline $5 \mathrm{~V}-0.25 \mathrm{Zr}-0.5 \mathrm{O}$ & -- & -- & 56 & 0.25 & -- & -- \\
\hline $2.5 \mathrm{~V}-0.5 \mathrm{Ti}-0.5 \mathrm{C}$ & -- & - & 56 & 0.26 & $-\cdot$ & -- \\
\hline $5 \mathrm{~V}-0.5 \mathrm{Ti}-0.5 \mathrm{C}$ & -- & -- & 56 & 0.42 & - & -- \\
\hline $2.5 \mathrm{~V}-0.5 \mathrm{Zr}-0.5 \mathrm{C}$ & -- & - & 56 & 0.44 & -- & - \\
\hline $5 \mathrm{~V}-0.5 \mathrm{Zr}-0.5 \mathrm{C}$ & -- & -- & 56 & 0.31 & -- & -- \\
\hline $5 \mathrm{~V}$ & -- & -- & 56 & 0.44 & -- & - \\
\hline $10 \mathrm{Zr}$ & -- & -- & -- & -- & 98 & -5.93 \\
\hline $10 \mathrm{Ti}$ & -- & - & - & - & 98 & 0.43 \\
\hline
\end{tabular}

(a) Off test.

(b) Losing weight. 
heaters around the specimen, but within the capsule; will be cast into aluminum blocks to achieve the maximum heat-transfer properties. These heaters are to maintain spe:imen temperature during the time the reactor is inoperative and to supply the heat required during irradiation that is not produced by gamma heating in the specimen. The external load to the specimen will be produced by bellows action from the internally presisurized capsule. A rated external load of 500 psi can be withstood by the bellows. The capsule body itself will withstand approximately 1500 psi. Extension of the total length of the specimen during test will be indicated by a linear variable permeance transduce $r$ attached to the bellows interface.

Progress during the past work periodwas related to check tests of components prio: to assembly. The stainless steel bellows were subjected to vacuum and distortion tests. One unit was tested to a 3000-psi internal pressure. The electric heaters were received, and their resistances appear to be as specified. Each element is being $\mathrm{X}$-rayed. The thermal and pressure mock-up experiments are being conducted. The assembly of parts for both the in-pile and out-of-pile capsules will proceed concurrently. The insertion of the capsule in the WTR is scheduled for the cycle beginning in June, 1960.

Tensile tests have been performed at room temperature, 450,550 , and $650 \mathrm{~F}$ as part of the strain-aging studies. A yield-point phenomenon has been observed in Zircaloy-2 after straining and aging for $30 \mathrm{~min}$ at all temperatures, except room temperatire. This appears to be evidence of strain aging. Additional tests are planned to invesligate the presence of a yield point as related to the aging temperatures and the heat-1reated condition of the starting material.

Analysis of internal-friction data obtained at temperatures greater than $600 \mathrm{~F}$ indicates that there is no diffusion-controlled mechanisms in operation in this temperature $r$ ange. As part of the strain-aging studies, attempts are being made to relate the yield-point phenomenon observed by tensile testing with the diffusion of either solute or inters itial atoms to dislocation sites. Negative results are either related to the speed of diffision of the solute or interstitial atoms or the absence of a diffusion mechanism. The temperature range currently being investigated is from room temperature to $600 \mathrm{~F}$, the range in which the yield point was observed in the tensile tests.

Improvements in techniques for the preparation of thin films of zirconium for electron microscopy have been made. Electron microscopy is being used to determine dislocation density and to study dislocation movement. Light-microscope studies have been made, and replica techniques are being used for electron-microscope studies on annealed Zircaloy- 2 and on Zircaloy-2 exhibitir.g a yield point during tensile testing. No difference was observed in the microstructures of the two samples at $250 \mathrm{X}$ by light microscope or at 35,000X with replicas in the electron microscope.

\section{Determination of Oxygen in Sodium at Concentrations Below 10 PPM}

D. Ensminger, D. R. Grieser, E. H. Hall, J. W. Kissel, J. McCallum, and W. H. Goldthwaite

Methods of determining the impurity level in sodium are being evaluated. The objectiv $ə$ is to demonstrate the feasibility of detecting oxygen at levels of $10 \mathrm{ppm}$ and 
below with a $\pm 1 \mathrm{ppm}$ sensitivity. Initially, studies are being made to determine the sensitivity of potential detection methods to impurity levels in the 20 to $100-p p m$ range.

Four of the methods being studied are not specific for oxygen. These methods are: (1) ellipsometry, (2) electrical-resistivity measurement, (3) plugging-indicator technique, and (4) vacuum distillation. The work on these will be carried forth only far enough to allow estimation of their potential sensitivity to total saturable impurities.

The evaluation of a polarographic technique has suffered from lack of a suitable organic electrolyte. Potential electrolytes, such as fused salts, involve a much larger effort than practical, at present, and therefore this study is being suspended.

The study of the application of mass spectrometry to the determination of oxygen in sodium is being continued. It has been found that extrusion-press sodium sample sizes can be repeated with less than 10 per cent average deviation. Studies are being made to determine the relative ion abundance of electron-bombarded sodium oxide vapor. Future work will include the study of sodium carbonate and sodium hydroxide to evaluate the feasibility of analyzing for the se impurities in addition to sodium oxide.

\section{Wear and Friction of Sliding Surfaces in Liquid Sodium}

J. W. Kissel, W. Glaeser, and W. H. Goldthwaite

The investigation of low-speed friction and wear behavior of various materials immersed in molten sodium has revealed that, under certain conditions, molybdenum exhibits good bearing properties. Intensive study of the parameters involved has indicated that surface films are very important ameliorants to the friction and wear .' processes. Current effort involves development of techniques for coating stainless steel specimens with molybdenum dioxide - the film associated with low friction and little surface damage from sliding.

Molybdenum dioxide has been produced by the following method: a molybdenum surface is heated above $300 \mathrm{C}$ in air to produce $\mathrm{MoO}_{3}$ and then is subsequently heated to $400 \mathrm{C}$ in a reducing environment (hydrogen, molybdenum metal, or other reducing agent). The $\mathrm{MoO}_{2}$ formed can then be evaporated in vacuum onto metallographically prepared stainless steel flat surfaces. Friction and wear between flats prepared in this way and a polished molybdenum ball will be measured and the data will be compared with previously obtained friction data for molybdenum sliding on molybdenum.

Baseline friction data are currently being obtained between specimen pairs of tool steel, pairs of stainless steel, and between a Type 347 stainless steel flat and a molybdenum ball. Both dry and molten-sodium-lubricated conditions are being investigated. Simultaneous recording of friction and electrical contact $r$ esistance between the rubbing test surfaces has been developed and utilized. The electrical-resistance measurements are being used to detect the presence or breakdown of an insulating film and will be used to interpret sliding-friction characteristics. 
Specimens of Inconel, Inconel X, tungsten, tungsten carbide, and titanium carbide have been prepared and are now available for friction studies. Of these materials, tungslen versus tungsten will be investigated first. It is believed this combination will exhibit surface-chemistry effects similar to molybdenum. 


\title{
STUDIES OF FUEL A.LLOYS (AEC-DRD)
}

\author{
R. F. Dickerson
}

\begin{abstract}
Development of Niobium-Uranium Alloys . . . . . . . . . . . B-2 Development of Thorium-Uranium Alloys . . . . . . . . . . . B-4
\end{abstract}

Two specimens of niobium-10 w/o uranium alloy have been tested in tension at $2200 \mathrm{~F}$ in vacuum. One of the specimens exhibited an ultimate strength of 41,000 psi and the other an ultimate strength of 32,000 psi. Additional tests are being performed in ar attempt to resolve this spread in strength values. A series of niobium-base binary alloys containing 10 to $60 \mathrm{w} / 0$ uranium has been exposed to $600 \mathrm{~F}$ water for 252 days. Although all of the alloys have a dull black coating, most of them show weight lossıs. A study to determine the temperature of recrystallization as defined by a $\mathrm{l}-\mathrm{hr}$ heat treatment of 80 per cent cold-worked material has been initiated, and the study of the $\epsilon$ ffects of oxygen on the composition limits of the gamma-immiscibility loop is continuing.

Room-temperature tensile tests have been performed on thorium-base binary alloys containing 5,10 , and $20 \mathrm{w} / 0$ uranium, on thorium-10 w/o uranium alloys containing a ternary addition of $1.5 \mathrm{w} / 0$ molybdenum, $2 \mathrm{w} / 0$ molybdenum, $2 \mathrm{w} / 0$ niobium, or $10 \mathrm{w} / 0$ zirconium, and on a thorium-10 w/o uranium-10 w/o zirconium-2 w/o niob:um alloy. The results indicate that the molybdenum and niobium additions do not incriase the tensile properties of the thorium-uranium binary alloy significantly, but that zirconium and zirconium-niobium additions result in about a 50 per cent increase in ultimate strength. This trend was also noted at 600 and $700 \mathrm{C}$. On the other hand, creep data obtained at $600 \mathrm{C}$ indicate that molybdenum and niobium additions improve the creep properties, while the zirconium and zirconium-niobium additions have little or nis effect.

Although chemical analyses of arc-melted $\mathrm{ThN}$ revealed nitrogen contents of less than $5.69 \mathrm{w} / \mathrm{o}$ (stoichiometric), X-ray diffraction showed the presence of only ThN. The presence of inert material is suspected, and attempts will be made to analyze for insoiubles. 
The potential of niobium-rich niobium-uranium alloys as high-temperature metallic fuels has lead to a program to investigate the fabrication characteristics, mechanical and physical properties, corrosion behavior in selected media, and irradiation behavior of these alloys.

Alloys containing from 10 to $60 \mathrm{w} / 0$ uranium were prepared for study from three grades of niobium containing from 0.03 to $0.07 \mathrm{w} / \mathrm{o}$ oxygen and 0.02 to $0.74 \mathrm{w} / \mathrm{o}$ zirconium. No effects on the fabrication characteristics or tensile properties due to differences in oxygen or zirconium contents were noted. No significant effect on corrosion behavior has been observed.

Niobium-uranium alloys have been tested in $600 \mathrm{~F}$ water for a total of 252 days. The data obtained are shown in Table B-1. Although the majority of the alloys being tested show weight losses, a few alloys are still gaining weight. All specimens being tested have a dull black oxide coating.

Specimens being corrosion tested in sodium at $1500 \mathrm{~F}$ have been returned to test for an additional 500 hrs of exposure.

A stress-rupture test of a niobium-10 w/o uranium specimen at $2200 \mathrm{~F}$ under a $10,000-p s i$ load ended when the specimen broke after $332 \mathrm{hrs}$ on test. Although up to $300 \mathrm{hrs}$ this specimen showed no perceptible deformation after initial loading, it exhibited an elongation of 35.4 per cent after break. Additional specimens have been prepared and the stress necessary to produce rupture in $100 \mathrm{hrs}$ at $2400 \mathrm{~F}$ will be determined.

The ultimate tensile strength of cold-worked niobium-10 w/o uranium specimens is being determined at $2200 \mathrm{~F}$ in vacuum. One specimen exhibited an ultimate strength of 41,000 psi and an elongation of 12 per cent; a second specimen exhibited an ultimate strength of $32,000 \mathrm{psi}$ and 15 per cent elongation. A third specimen will be run in an attempt to resolve the spread between these values.

A study to determine the temperature of recrystallization as defined by a $1-\mathrm{hr}$ heat treatment of 80 per cent cold-worked material has been initiated. Hardness measurements and metallography will be employed as tools in this study.

Capsules are being designed for irradiation studies of niobium-10, -20 , and -30 $\mathrm{w} / 0$ uranium alloys and two niobium $-30 \mathrm{w} / \mathrm{o}$ uranium alloys containing 10 and $20 \mathrm{w} / \mathrm{o}$ zirconium additions. It is planned to irradiate specimens of these alloys to approximately 1 a/o burnup at 1600 and $1800 \mathrm{~F}$.

Niobium-uranium alloys containing 20 to $58 \mathrm{w} / 0$ niobium are being heat treated at temperatures of 650 to $940 \mathrm{C}$ as part of an investigation of the effects of oxygen on the composition limits of the gamma-immiscibility loop which occurs in this system. The alloys were prepared from niobium containing nominal concentrations of 90, 1000, and 
TABLE B-1. CORROSION DATA FOR NIOEIUM-URANIUM ALLOYS ${ }^{(a)}$ IN 600 F WATER

\begin{tabular}{|c|c|c|c|c|c|}
\hline \multirow{2}{*}{$\begin{array}{c}\text { Nominal } \\
\text { 4lloy Content } \\
\text { (Ba]ance Niobium), } \\
\mathrm{w} / \mathrm{o}\end{array}$} & \multicolumn{2}{|c|}{ Impurity Content } & \multirow{2}{*}{$\begin{array}{l}\text { Specimen } \\
\text { Condition } \\
\end{array}$} & \multicolumn{2}{|c|}{$\begin{array}{c}\text { Total Weight Change, } \\
\text { mg per } \mathrm{cm}^{2} \\
\end{array}$} \\
\hline & $\mathrm{ppm}$ & $w / o$ & & In 238 Days & In 252 Days \\
\hline \multirow[t]{3}{*}{$10 \mathrm{U}$} & 680 & 0.74 & Fabricated & 0.65 & 0.73 \\
\hline & 1190 & 0.17 & Fabricated & -0.83 & -1.23 \\
\hline & 3170 & 0.02 & Fabricated & -3.79 & -3.93 \\
\hline \multirow[t]{3}{*}{$20 \mathrm{U}$} & 458 & 0.74 & Fabricated & 0.95 & 0.93 \\
\hline & 523 & 0.17 & Fabricated & 2.01 & 2.33 \\
\hline & 198 & 0.02 & Fabricated & 0.77 & 0.76 \\
\hline \multirow[t]{3}{*}{$30 \mathrm{U}$} & 586 & 0.74 & As cast & 0.0 & -0.11 \\
\hline & 669 & 0.17 & Fabricated & -2.52 & -2.75 \\
\hline & 165 & 0.02 & As cast & -0.78 & -0.86 \\
\hline \multirow[t]{3}{*}{$40 \mathrm{U}$} & 661 & 0.74 & As cast & 0.46 & 0.63 \\
\hline & 579 & 0.17 & Fabricated & 0.21 & 0.23 \\
\hline & 261 & 0.02 & As cast & 0.63 & 0.75 \\
\hline \multirow[t]{3}{*}{$50 \mathrm{U}$} & 375 & 0.74 & As cast & 0.04 & -0.17 \\
\hline & 334 & 0.17 & Fabricated & 0.27 & 0.24 \\
\hline & 271 & 0.02 & As cast & -0.32 & -0.88 \\
\hline \multirow[t]{2}{*}{$60 \mathrm{U}$} & 471 & 0.74 & As cast & -6.56 & -7.53 \\
\hline & 273 & 0.17 & Fabricated & -5.92 & -6.47 \\
\hline , & 192 & 0.02 & As cast & -1.93 & -2.16 \\
\hline
\end{tabular}

(a) Average of duplicate specimens.

(b) Analyzed value.

(c) Nominal composition. 
3000 ppm of oxygen. Ternary uranium-niobium-zirconium alloys containing 50 and 60 $\mathrm{w} / 0$ uranium are also being heat treated at temperatures of 500, 650, and $750 \mathrm{C}$ to study the effects of zirconium on the niobium-uranium immiscibility loop. Alloys of uranium$10 \mathrm{w} / 0$ niobium annealed at temperatures of 725,750 , and $800 \mathrm{C}$ have been examined metallographically. The effects of the different oxygen contents in the alloys could not be determined from this examination; the observations were hindered by inhomogeneity of the alloy structures. The two-phase region observed in the alloys was distributed over only a small portion of each specimen. Further analysis will be attempted with the aid of an electron-beam microanalyzer. The compositions of the gamma 1 matrix and the gamma 2 particles will be investigated by this means.

\section{Development of Thorium-Uranium Alloys}

M. S. Farkas, R. W. Endebrock, A. A. Bauer, and R. F. Dickerson

Improvement in the irradiation and corrosion properties of thorium-uranium alloys is the objective of the present investigation. The effect of thorium purity, castir methods, and fabrication on the size and distribution of uranium-rich particles is being studied as is the effect of alloy additions on the properties of the binary alloys. Alloy additions include niobium, molybdenum, zirconium and zirconium plus niobium. The preparation and properties of thorium and thorium-uranium carbides and nitrides are also being investigated.

Multiple arc melting of thorium under 2-1/2 atm of nitrogen has been performed in an attempt to prepare stoichiometric ThN. One button was prepared by remelting three times, inverting the button between each melting pass. A second button was similarly prepared by remelting six times. Kjeldahl analyses revealed a nitrogen content of $5.38 \mathrm{w} / 0$ for the three-cycle specimen and $5.02 \mathrm{w} / 0$ for the six-cycle specimen. The stoichiometric nitrogen content of $\mathrm{ThN}$ is $5.69 \mathrm{w} / \mathrm{o}$. Inspection of specimens by $\mathrm{X}$-ray diffraction showed that only $\mathrm{ThN}$ was present in either specimen. It is suspected that inert material, probably $\mathrm{ThO}_{2}$, present initially or possibly formed during the remelting procedure may be the reason that stoichiometric ThN was not indicated by the chemical analyses. Accordingly, specimens will be inspected metallographically and analyzed for insolubles.

Room-temperature tensile test data for thorium $-5,-10$, and $-20 \mathrm{w} / 0$ uranium binary alloys, thorium $-10 \mathrm{w} / \mathrm{o}$ uranium-1.5 w/o molybdenum, $-2 \mathrm{w} / \mathrm{o}$ niobium, $-10 \mathrm{w} / \mathrm{o}$ zirconium ternary alloys, and a thorium-10 w/o uranium-10 w/o zirconium-2 w/o niobium alloy are reported in Table B-2. Tensile data obtained from tests conducted at 600 and $700 \mathrm{C}$ and reported previously show the same trend, namely that alloys containing molybdenum and niobium show no significant increase in the tensile properties over those of the thorium-10 w/o uranium-base alloy; however, additions of zirconium and zirconium-niobium result in about a 50 per cent increase in ultimate tensile strength.

Creep data obtained at $600 \mathrm{C}$ are presented in Table B-3. Also, preliminary data at $700 \mathrm{C}$ have been obtained. At these temperatures, molybdenum and niobium additions to the thorium-10 w/o uranium alloy are very beneficial; however, zirconium and zirconium-niobium additions which increase high-temperature tensile properties are 
TABLE B-2. ROOM-TEMPERATURE TENSILE PROPERTIES OF THORIUM-URANIUM AND THORIUM-URANIUM-BASE ALLOYS

\begin{tabular}{|c|c|c|c|}
\hline $\begin{array}{l}\text { Alioy Composition } \\
\text { (Balar ce Thorium), w/o }\end{array}$ & $\begin{array}{l}0.2 \text { Per Cent Offset } \\
\text { Yield Strength, psi }\end{array}$ & $\begin{array}{l}\text { Ultimate Tensile } \\
\text { Strength, psi }\end{array}$ & $\begin{array}{l}\text { Elongation in } 1 \text {-In. } \\
\text { Gage Length, per cent }\end{array}$ \\
\hline $5 \mathrm{U}$ & 27,900 & 39,300 & 23 \\
\hline $1(\mathrm{U}$ & 26,900 & 37,700 & 14 \\
\hline $2(\mathrm{U}$ & 32,100 & 42,000 & 30 \\
\hline 1( U $-1.5 \mathrm{Mo}$ & 26,400 & 41,000 & 15 \\
\hline $16 \mathrm{U}-2 \mathrm{Nb}$ & 22,900 & 35,400 & 22 \\
\hline $10 \mathrm{U}-10 \mathrm{Zr}$ & 35,200 & 53,200 & 12 \\
\hline $1(\mathrm{U},-10 \mathrm{Zr}-2 \mathrm{Nb}$ & 39,200 & 60,400 & 14 \\
\hline
\end{tabular}

TABLE B-3, CREEP DAT A OBT AINED FROM ANNEALED THORIUM-URANIUM-BASE ALLOYS AT $600 \mathrm{C}$

\begin{tabular}{lc}
$\begin{array}{c}\text { Composition } \\
\text { (Balance Thorium), w/o }\end{array}$ & $\begin{array}{c}\text { Stress to Give a } \\
0.01 \text { Per Cent Per Hr, psi }\end{array}$ \\
\hline $10 \mathrm{U}-1.5 \mathrm{Mo}$ & 5700 \\
$10 \mathrm{U}-2 \mathrm{Nb}$ & 4900 \\
$5 \mathrm{U}$ & 3900 \\
$10 \mathrm{U}$ & 3500 \\
$20 \mathrm{U}$ & 3200 \\
$10 \mathrm{U}-10 \mathrm{Zr}(\mathrm{a})$ & 2000 \\
$10 \mathrm{U}-10 \mathrm{Zr}-2 \mathrm{Nb}$ & 1700 \\
\hline
\end{tabular}

(a) Estimated from a creep test at one stress only. 
deleterious to creep properties. The reason for this apparent reversal of strength properties must be investigated further. However, with the knowledge of structures and the strength data which is available one can tentatively put forth an explanation. Creep rates exhibited by binary thorium-uranium alloys increase as the uranium content increases because of the increasing amount of uranium particles in the structure which tend to reside in the grain boundaries. This low-strength uranium is effective in reducing creep strength. When molybdenum or niobium is added to the alloy, the uranium phase is strengthened. On the other hand, when zirconium is added it partitions to the thorium matrix and has little or no effect on the strength of the uranium particles. 
FISSION-GAS RELEASE FROM REFRACTORY FUELS (AEC-DRD)

J. B. Melehan, D. A. Vaughan, R. H. Barnes,

H. Sheets, S. D. Beck, and F. A. Rough

Characterization of Sintered $\mathrm{UO}_{2}$ and Model of Gas Release . . . C-2 Diffusion in $\mathrm{UO}_{2}$. . . . . . . . . . . . . . . . . . $\mathrm{C}-4$ Preparation for In-Pile Study . . . . . . . . . . . . . . C-4

Study of the mechanism of gas release from $\mathrm{UO}_{2}$ is continuing. Three xenondiffixion runs have been completed by postirradiation-heating techniques. These runs appear to be giving useful data, although the analysis is not complete. The in-pile stucy of gas release has been delayed due to equipment difficulties, but will be resumed in the near future. 
The internal pore and grain-boundary structures of sintered $\mathrm{UO}_{2}$ bodies are being determined to aid in understanding fission-gas release during irradiation and postirradiation heat treatments. Previous pore analyses have indicated that the surface area of a polished section of $\mathrm{UO}_{2}$ would be increased by a relatively small factor (less than 2) due to the pores in the section of bodies having a theoretical density of 95 per cent by lineal analysis. During the past 2 months, specimens with a large number of large pores have been studied. Although pycnometric density measurements indicated that the se bodies were approximately 95 per cent of theoretical density, the lineal analysis indicated densities of the order of 80 per cent. Surface-area measurements by nitrogen absorption were found to be $4480 \mathrm{~cm}^{2}$ per $\mathrm{cm}^{3}$. In the present microscopic analysis of pore surface area, an attempt was made to determine the total pore surface area per unit volume of the body. The results varied considerably for two bodies examined. One which had a large number of large pores $(>3 \mu)$ gave a pore surface area of $30 \mathrm{~cm}^{2}$ per $\mathrm{cm}^{3}$, while another which had a few large pores and many small $(<3 \mu)$ pores gave a surface area of $2 \mathrm{~cm}^{2}$ per $\mathrm{cm}^{3}$. The pore structure alone, even if interconnected, would not account for the high surface area obtained by nitrogen absorption. However, one might assume that grain boundaries would provide the connecting link between the surface of the body and a large fraction of the pores within the body. An analysis of the grain-boundary surface area gave $1800 \mathrm{~cm}^{2}$ per $\mathrm{cm}^{3}$. This is of the same order of magnitude as that obtained by nitrogen absorption.

Further studies are being made to obtain a clearer picture of the meaning of surface-area measurements obtained by gas adsorption in terms of pore structure and microstructure. It is too early, however, to attempt to draw any conclusions from this work. In order to continue the se studies of pore structure and to study the diffusion of gaseous fission products in $\mathrm{UO}_{2}$, additional specimens are being prepared.

Previously, five groups of specimens were prepared by selectively altering fabrication conditions. The conditions used, together with densities, porosities, oxygenuranium ratios, and average grain size, are shown in Table C-l. Microscopic examination of polished and etched surfaces showed that Specimens 79-28 and 79-30 were quite similar in structure. Both had clusters of pores located between grains and distributed unevenly throughout the specimens. There was considerable porosity within the grains. Specimen 79-26 also contained clusters of pores, but had considerably fewer pores within the grains, and more pores isolated in the grain boundaries. Specimens 80 and 81 had fewer clusters of pores; the concentration of pores within the clusters in these specimens was lower than in Specimens 79-26, 79-28, and 79-30. Most of the porosity in Specimens 80 and 81 was intragranular.

Details of the preparation of additional specimens made during this period are also shown in Table C-1. Specimens 89 and 90, having large grain sizes, were made for surface-area investigations. The remainder of the specimens were made to evaluate the addition of increased amounts of binder or the use of high-temperature calcination of the starting powder prior to pressing as two possible techniques for preparing specimens having relatively uniform structure and 5 to 10 per cent of open porosity. Microscopic examinations of the se specimens are planned.

Future work also will include continuation of the investigation of the effect of sintering conditions on the density, oxygen-to-uranium ratio, and microstructure of $\mathrm{UO}_{2}$ pellets made from oxidized $\mathrm{UO}_{2}$. 
TABLE C-1. PROCESSING CONDITIONS, DENSITIES, POROSITIES, AND OXYGEN-TO-URANIUM RATIOS OF UO 2 SPECIMENS (a)

\begin{tabular}{|c|c|c|c|c|c|c|c|c|c|c|c|c|c|}
\hline \multirow[b]{4}{*}{ Specimen } & \multirow{4}{*}{$\begin{array}{l}\text { Binder } \\
\text { Content }(b), \\
w / o\end{array}$} & \multirow{2}{*}{\multicolumn{4}{|c|}{ Processing Conditions }} & \multicolumn{6}{|c|}{ Density and Porosity } & \multirow{4}{*}{$\begin{array}{l}\text { Oxygen-to- } \\
\text { Uranium } \\
\text { Ratio }\end{array}$} & \multirow{4}{*}{$\begin{array}{c}\text { Average } \\
\text { Grain Size } \\
\mu \\
\end{array}$} \\
\hline & & & & & & \multirow{2}{*}{\multicolumn{2}{|c|}{ Sintering Conditions $(c)$}} & \multirow{2}{*}{\multicolumn{2}{|c|}{ Bulk Density }} & \multirow{2}{*}{\multicolumn{2}{|c|}{$\begin{array}{l}\text { Porosity, } \\
\text { per cent }\end{array}$}} & & \\
\hline & & \multirow[b]{2}{*}{$\begin{array}{l}\text { Ball Milling } \\
\text { Time, hr }\end{array}$} & \multirow{2}{*}{$\begin{array}{c}\text { Preoxidation } \\
\text { Temperature, } \\
\text { F }\end{array}$} & \multirow{2}{*}{$\begin{array}{c}\text { Reduction } \\
\text { Temperature, } \\
\text { F }\end{array}$} & \multirow{2}{*}{$\begin{array}{c}\text { Forming } \\
\text { Pressure, } \\
\text { psi }\end{array}$} & & & & & & & & \\
\hline & & & & & & $\begin{array}{c}\text { Temperature, } \\
\mathrm{F}\end{array}$ & $\begin{array}{c}\text { Time, } \\
\text { hr }\end{array}$ & $\begin{array}{l}\text { G per } \\
\mathrm{Cm}^{3}\end{array}$ & $\begin{array}{l}\text { Per Cent of } \\
\text { Theoretical }\end{array}$ & $\begin{array}{l}\text { Open } \\
\text { Pores }\end{array}$ & $\begin{array}{c}\text { Closed } \\
\text { Pores }\end{array}$ & & \\
\hline $79-26$ & $1-1 / 2$ & 2 & -- & -- & 40,000 & 2600 & 1 & 10.17 & 92.6 & 0.0 & 8.4 & 2.00 & 5 \\
\hline $79-28$ & $1-1 / 2$ & 2 & -- & -- & 40,000 & 2800 & 1 & 10.38 & 94.5 & 0.0 & 5.5 & 2.00 & 14 \\
\hline $79-30$ & $1-1 / 2$ & 2 & -- & -- & 40,000 & 3000 & 1 & 10.38 & 94.5 & 0.0 & 5.5 & 2.00 & 14 \\
\hline 80 & $1-1 / 2$ & 15 & - & - & 20,000 & 3000 & 1 & 10.58 & 96.3 & 0.0 & 3.7 & 2.01 & 20 \\
\hline 81 & $1-1 / 2$ & 15 & 1000 & -- & 20,000 & 3000 & 1 & 10.58 & 96.3 & 0.0 & 3.7 & 2.00 & 20 \\
\hline 89 & $1-1 / 2$ & 15 & 1000 & -- & $\bar{z} 0,000$ & $\overline{3} 0 \overline{0} 0$ & 15 & $i \bar{u} . \overline{8} \bar{z}$ & $\bar{y} \overline{8} . \overline{6}$ & $\bar{u} . \overline{0}$ & 1.4 & $\bar{z} . \bar{U} \bar{I}$ & -- \\
\hline 90 & $1-1 / 2$ & 2 & .- & -- & 40,000 & 3000 & 15 & 10.65 & 97.1 & 0.0 & 2.9 & 2.02 & -- \\
\hline $90-3$ & 3 & 2 & -. & -- & 40,000 & 2600 & 1 & 9.90 & 90.3 & 7.7 & 2.0 & 2.02 & -- \\
\hline $90-6$ & 6 & 2 & -- & -- & 40,000 & 2600 & 1 & 9.31 & 84.9 & 14.2 & 0.9 & 2.03 & -- \\
\hline 97 & $1-1 / 2$ & 15 & 1000 & 1830 & 40,000 & 2600 & 1 & 9.80 & 89.3 & 8.5 & 2.2 & 2.02 & -- \\
\hline 98 & $1-1 / 2$ & 15 & 1000 & 2200 & 40,000 & 2600 & 1 & 9.25 & 84.3 & 15.5 & 0.2 & 2.02 & -- \\
\hline
\end{tabular}

(a) Densities and porosities are the average of measurements on three to seven pellets, and were measured by xylene immersion. Theoretical density of UO $\mathrm{O}_{2}$ was taken as $10.98 \mathrm{~g}$ per $\mathrm{cm}^{3}$.

(b) Davidson $\mathrm{UO}_{2}$ was used for all specimens. Beeswax dissolved in $\mathrm{CCl}_{4}$ was used as a binder; the $\mathrm{CCl}_{4}$ was allowed to evaporate at room temperature prior to pressing.

(c) Sintered in a flowing hydrogen atmosphere.

(d) Estimated from ASTM steel grain-size series. 


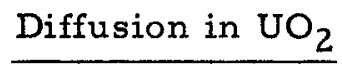

The experimental study of fission-gas release from uranium dioxide during postirradiation heat treatment is continuing.

During March, measurements of fission-gas release from flat plates of Norton single-crystal uranium dioxide were made at 1188 and $1402 \mathrm{C}$. Three postirradiation heat treatments, which include the one at $1205 \mathrm{C}$ reported in the last monthly report (BMI-1423) have now been completed. Detailed analysis of the data is in progress. In all three heat treatments, the variation of xenon-release rate with time exhibited the same characteristic pattern. Upon initiation of heat treatment, a short pulse of xenon was observed, and the release rate increased very rapidly to a maximum and then fell rapidly to a relatively low rate. This occurred within a period of less than $40 \mathrm{~min}$. Following this initial peaking, the xenon-release rate built up to a maximum relatively slowly compared to the first rise, and then dropped off linearly with time. The time for the release rates to reach the maximum varied between 20 to $100 \mathrm{~min}$.

During each heat treatment, the concentration of oxygen and water vapor in the helium carrier stream in contact with the specimen decreased gradually. On the average, oxygen decreased from about 20 to $9 \mathrm{ppm}$ while water ranged from 100 to $5 \mathrm{ppm}$. Adequate data are not available at this time to determine the significance of the helium impurities on xenon release.

Other fission products besides xenon were also released; however, only xenon can be determined quantitatively with the present apparatus. Iodine and tellurium release was detected in all three runs. Gamma-ray spectrometric analysis of the fission products released during the run at $1402 \mathrm{C}$ indicated the presence of cerium, cesium, ruthenium, and other fission products.

Measurements of release rates of fission gases from additional plates of singlecrystal uranium dioxide in the range of 1200 to $1600 \mathrm{C}$ are scheduled to continue.

\section{Preparation for In-Pile Study}

Vacuum-system failure in the beam-tube furnace has delayed the experimental program. The furnace has been removed for repairs.

Continuing mathematical analysis of the in-pile gas-release problems is treating the effects of reactor shutdown and of interruption in the specimen heating schedule on the diffusion release rates for the fission rare gases. 
GENERAL FUEL-ELEMENT DEVELOPMENT (AEC-DRD)

\author{
S. J. F'aprocki
}

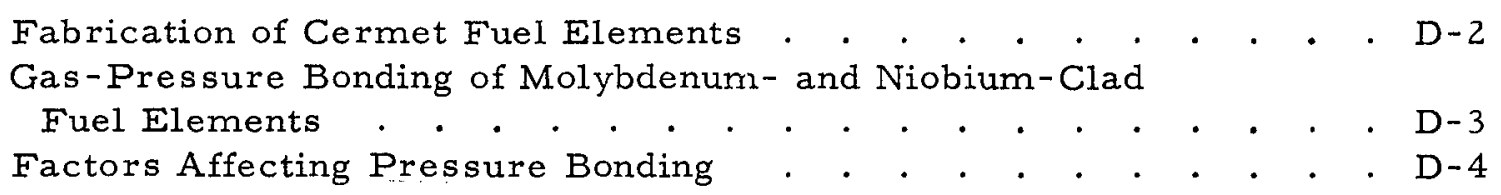

Fabrication techniques have been developed for the preparation of dense cermet fuel materials consisting of a mixture of 80 volume per cent $\mathrm{UO}_{2}$ and 20 volume per cent of aither chromium, molybdenum, niobium, or stainless steel. Current studies are primarily concerned with the determination of physical and mechanical properties of the se materials.

The gas-pressure-bonding technique js being utilized for the solid-phase bonding of niobium and molybdenum. Techniques have been developed for producing highstrength ductile niobium bonds. Methods have also been developed for the bonding of molybdenum; however, since bonding is achieved above the recrystallization temperature, the molybdenum is brittle, exhibiting extreme directional properties.

A fundamental study is being conducted to investigate the kinetics involved in a solid-phase bonding process that uses heat and pressure. It has been determined that the bond characteristics are directly related to the surface roughness, temperature, anc. pressure. The studies have shown that optimum bonding with complete grain growth across the interface is consistently achieved at the high points of a rough surface. Thise areas are the initial contact points and consequently are subjected to the highest pressure. 
Fabrication of Cermet Fuel Elements

S. J. Paprocki, D. L. Keller, G. W. Cunningham, and D. E. Kizer

Measurements of physical and mechanical properties are being made on 80 volume per cent $\mathrm{UO}_{2}$ cermets prepared by pressure-bonding techniques.

Thermal-conductivity measurements have been made on two 80 volume per cent $\mathrm{UO}_{2}$-stainless steel cermet rods and one 80 volume per cent $\mathrm{UO}_{2}$-chromium cermet rod. The thermal-conductivity specimens were fabricated by pressure-bonding green-pressed pellets inserted in stainless tubes for $3 \mathrm{hr}$ at $2300 \mathrm{~F}$ at a helium gas pressure of $10,000 \mathrm{psi}$. The rods were 0.587 to $0.650 \mathrm{in}$. in diameter by $2.250 \mathrm{in}$. in length after machining to remove the stainless steel tubes. Table D-l shows the measured mean thermal-conductivity values and descriptions of the three cermets. Additional thermalconductivity measurements are being made on 80 volume per cent $\mathrm{UO}_{2}$-molybdenum and 80 volume per cent $\mathrm{UO}_{2}$-niobium cermets.

TABLE D-1. MEAN THERMAL-CONDUCTIVITY VALUES OF UO 2 CERMETS

\begin{tabular}{|c|c|c|c|}
\hline & $\begin{array}{l}\text { Specimen } \\
\text { TC }-102\end{array}$ & $\begin{array}{l}\text { Specimen } \\
\text { TC-103 }\end{array}$ & $\begin{array}{l}\text { Specimen } \\
\text { TC-104 }\end{array}$ \\
\hline \multicolumn{4}{|c|}{$\begin{array}{l}\text { Thermal Conductivity of } \\
\text { Temperature Shown, } \\
w /(\mathrm{cm})(\mathrm{C})\end{array}$} \\
\hline $100 \mathrm{C}$ & 0.075 & 0.085 & 0.171 \\
\hline $200 \mathrm{C}$ & 0.071 & 0.076 & 0.162 \\
\hline $300 \mathrm{C}$ & 0.070 & 0.072 & 0.156 \\
\hline $400 \mathrm{C}$ & 0.073 & 0.073 & 0.152 \\
\hline $500 \mathrm{C}$ & 0.078 & 0.079 & 0.151 \\
\hline $600 \mathrm{C}$ & 0.087 & 0.088 & 0.155 \\
\hline $700 \mathrm{C}$ & 0.098 & 0.100 & 0.163 \\
\hline $800 \mathrm{C}$ & 0.112 & 0.113 & 0.175 \\
\hline $900 \mathrm{C}$ & 0.125 & 0.127 & 0.190 \\
\hline Composition & $\begin{array}{l}80 \text { volume per cent } \\
\text { minus } 100 \text { plus } 140 \text {-mesh } \\
\text { high-fired } \mathrm{UO}_{2}^{-} \\
\text {Type } 302 \mathrm{~B} \text { stainless }\end{array}$ & $\begin{array}{l}80 \text { volume per cent } \\
\text { minus } 100 \text { plus } 140-\text { mesh } \\
\text { depleted spherical } \\
\text { UO }_{2} \text {-Type } 302 \text { B stainless }\end{array}$ & $\begin{array}{l}80 \text { volume per cent } \\
\text { minus } 100 \text { plus } 140 \text {-mesh } \\
\text { depleted spherical } \\
\mathrm{UO}_{2} \text {-chromium }\end{array}$ \\
\hline $\begin{array}{l}\text { Density, per cent of } \\
\text { theoretical }\end{array}$ & 98.4 & 97.2 & 97.1 \\
\hline
\end{tabular}

Cermets of 80 volume per cent minus 140 plus 200-mesh spherical $\mathrm{UO}_{2}$-Type $302 \mathrm{~B}$ stainless steel and molybdenum have been green pressed into cores 1 by 1 by 0.100 in. and pressure bonded in stainless steel and molybdenum sheets at both 2250 and $2300 \mathrm{~F}$ for $3 \mathrm{hr}$ under a helium gas pressure of $10,000 \mathrm{psi}$. The $2250 \mathrm{~F}$ temperature resulted in densities of 90.1 and 95.6 per cent of theoretical, respectively, for the molybdenum and stainless steel cermets. Pressure bonding at $2300 \mathrm{~F}$ resulted in respective cermet densities of 92 and 95 per cent of theoretical. Specimens 0.073 by 1.50 in. have been machined from these 1 by 1 -in. cermets for modulus-of-rupture testing. Since chipping occurred during machining on the sharp edges of the specimens, additional modulus-ofrupture specimens will be made in a rod configuration. 
Gas-Pressure Bonding of Molybdenum- and

Niobium-Clad F'uel Elements

S. J. Paprocki, E. S. Hodge, and P. J. Gripshover

Molybdenum and niobium retain their strengths at elevated temperatures and possess favorable nuclear properties which rake them potential cladding and structural matt:rials for high-temperature reactor applications. Fajrication of niobium-clad fuel elerents containing ceramic fuels is presently being emphasized.

Two flat-plate compartmentalized fuel elements, each containing six uranium dioxide cores, have been pressure bonded at $2100 \mathrm{~F}$ and 10,000 psi for $3 \mathrm{hr}$. The picture frarres were constructed from strip components; each element was divided by 0. 100-in. wide ribs into six individual core compartments. Fifteen-mil-thick cover plates were inclided on each side of each of these specimens.

The first of these specimens was fusion edge welded in a helium atmosphere; a special evacuation stem was provided at the $\epsilon$ nd of the fuel element to permit evacuation of the specimen. Final sealing of the element was accomplished by resistance upset welding while a vacuum was being applied. Eivaluation of this element was accomplished by burst testing. In this test, a small hole is drilled through cladding in the center of each compartment and pressure is applied internally until a failure of the cladding or cover plate-to-rib bond occurs. Two compartments of the edge-welded specimen were tested in this manner. In both cases, failure occurred through the cladding with no evidence of bond weakness. The specimen has been sectioned and is presently being examined metallographically.

The second specimen was pressure bonded in a Type 304 stainless steel can. Uranium dioxide was used as the spacer material between the can and the specimen. The purpise of this specimen was to determine the feasibility of utilizing uranium dioxide as a chennel-spacer material for subassembly bonding. Visual examination of this specimen after bonding revealed no evidence that the use of the ceramic spacer had interferec, with bonding. Evaluation of this specimen is presently being conducted.

Investigations to determine the strength of niobium-to-niobium bonds formed at $2100 \mathrm{~F}$ and $10,000 \mathrm{psi}$ for $3 \mathrm{hr}$ have been continued. Three standard tensile bars were mackined from rods which had been subjected to the bonding cycle described above; two of these rods contained butt bonds while the third was a solid rod used as a standard. When tested, one of the bonded specimens and the standard specimen possessed a strength of approximately $40,000 \mathrm{psi}$ with a reduction in area of 90 per cent. The failure in this bonded specimen did not occur at the bond interface. However, the second bonded specimen did fail at the bond interface. Examination of this bond revealed that insufficient flow occurred at $2100 \mathrm{~F}$ to permit intirnate contact of the niobium in this specimen at all points, thereby preventing satisfactory bonding from occurring. Bonding at a higher temperature would have produced the flow required for this type of bond interface.

To further investigate vertical-type bonds, two flat-plate specimens were prepared to study bonding of niobium interfaces of this geometry. Each of these specimens consistel of two 0.100 -in. - thick plates arranged to form a vertical-type bond. In the first specimen, the plates were merely butted against each other, while in the second a 45-deg level was machined on each piece to form a lap joint. These specimens were pressure bond $\mathrm{d}$ at $2100 \mathrm{~F}$ and $10,000 \mathrm{psi}$ for $3 \mathrm{hr}$. Evaluation of these specimens was based on 
bend tests on sections taken at $90 \mathrm{deg}$ to the bond interface. Results of these tests indicated that the butt joint failed after a bend of approximately 30 deg while the lap joint withstood a bend of $90 \mathrm{deg}$ before fracture of the bond occurred. Based on these and the tensile-specimen results, it appears that it will be desirable to bond at a higher temperature to obtain the flow necessary to achieve satisfactory bonding at vertical joints of niobium interfaces.

\section{Factors Affecting Pressure Bonding}

G. W. Cunningham and J. W. Spretnak

The mechanism and kinetics of solid-phase bonding of metals under application of heat and pressure is being investigated. At present, the emphasis is being placed upon experiments which will lead to an understanding of the nature of bond formed initially and the effect of pressure, temperature, grain size, and surface roughness on the nature of the bond.

For the study on the effect of pressure on placing the surfaces of the two pieces of metal in intimate contact, OFHC copper specimens previously annealed at $1400 \mathrm{~F}$ have been bonded at pressures from 200 to 24,000 psi and at temperatures from 400 to $1400 \mathrm{~F}$. Metallographic examination and measurement of specimens bonded at 400,600, 700, and $1000 \mathrm{~F}$ have been completed. In all cases, intimate contacts along the entire interface occurred at a pressure of about 60 per cent of the value for Vickers hot hardness expressed in pounds per square inch. The bond lines etch at a higher rate than grain boundaries, but intimate contact is described as the condition whereby uniform etching occurs along the entire bond line. When data on specimens pressed at 1200 and $1400 \mathrm{~F}$ are obtained, an attempt will be made to relate the data to mathematical relationships which have been developed for relating pressure to the size of indentation and the friction between the metal surfaces.

Specimens are also being prepared to determine the effect of surface roughness. Shaped surfaces with values of 125,250 , and $500 \mu$ in. rms and ground $8-\mu$ in. rms surfaces of OFHC copper annealed at $1830 \mathrm{~F}$ are being used. Specimens with mated $8-\mu$ in. rms surfaces, 8- $\mu$ in. surfaces pressed on 500- $\mu$ in. surfaces, and 500- $\mu$ in. mated surfaces with teeth running in different directions have been pressed at 1000 and $1200 \mathrm{~F}$ for a period of $30 \mathrm{~min}$ at $16,000 \mathrm{psi}$. Examinations of the interfaces indicate that when the two 8- $\mu$ in. surfaces are pressed together the entire surface is in fairly close contact but many pores are present along the interface, indicating that no large areas are in intimate contact. Very little grain growth occurred across the interface in the 30-min pressing time. When the two 500- $\mu$ in. surfaces are pressed in contact, grain growth occurs in large areas where good contact is obtained, but there are also a considerable number of large areas where there is no contact between surfaces. When the 500- $\mu$ in. surface is pressed on the $8-\mu$ in. surface, there is considerable grain growth, a few areas where neither bond line nor small voids can be detected, and an indication of a few areas where contact is not good. It is interesting to note that in these specimens grain growth across the interface is clearly related to the pressure at which the metal surfaces are placed in contact, i. e., grain growth occurs first at areas of initial contact and, consequently, at areas subjected to high pressures. Additional specimens are being prepared and will be pressed at 400 and $1200 \mathrm{~F}$. 
$\mathrm{D}-5$ and $\mathrm{D}-\underline{6}$

In order to study the effect of grain size, specimens have been annealed at 800 , 141)0, 1800, and $1900 \mathrm{~F}$ and along with cold-worked specimens will be pressed at tempe:atures of 400,1000 , and $1400 \mathrm{~F}$. 
GAS-PRESSURE BONDING OF CERAMIC, CERMET, AND DISPERSION FUEL ELEMENTS (AEC-FUEL CYCLE)

S. J. Faprocki

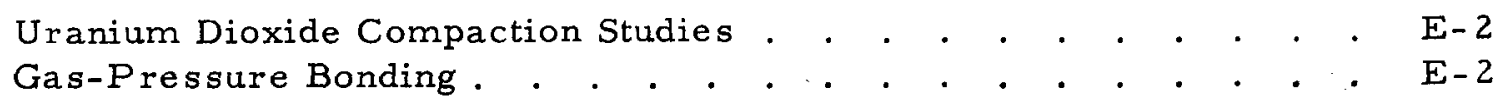

The objective of this program is to refine and further develop the gas-pressurebo ading technique for the fabrication of ceramic, cermet, and dispersion fuel elements. The gas-pressure-bonding process appears to be a promising method both for maintaining; or improving the quality of such elements and for reducing manufacturing costs. The program is based on studies which will accomplish the simultaneous densification and cliddding with stainless steel of powder fuels. The major emphasis is on the ceramic fue:1 systems; namely, uranium dioxide. 


\section{Uranium Dioxide Compaction Studies}

\section{S. J. Paprocki, S. W. Porembka, D. L. Keller,} and J. B. Fox

Uranium dioxide compaction studies have been directed toward attaining highgreen-density cores which will achieve a range of desired densities during subsequent pressure bonding. Various commercial powders and mistures have been evaluated on the basis of cold-compacting characteristics during pressing, tap packing, ultrasonic vibration, and centrifugal packing. Present efforts are concerned with the effects of various binder additions and with a more complete study of uranium dioxide mixtures.

A study to optimize the amount of various binder additions needed in cold pressing uranium dioxide is in progress. For the initial tests, the amount of Ceremul "C" and Carbowax 6000 contained as a binder with Spencer fused oxide was varied in compacts pressed at 40 to $50 \mathrm{tsi}$. Optimum cold-pressed densities were attained with 1 per cent Ceremul "C" (9.58 g per $\mathrm{cm}^{3}$ ) and 3 per cent Carbowax 6000/MEOH (9.49 $\mathrm{g} \mathrm{per}^{3} \mathrm{~cm}^{3}$ ). These compacts subsequently resulted in calculated pressure-bonded densities of 92.1 and 91.3 per cent of theoretical density, respectively.

Additional studies of uranium dioxide mixtures consisting of a ceramic grade powder with either a fused or special dense grade powder have been initiated. Compacts containing 25,50 , and 75 w/o ceramic uranium dioxide with minus 100-, minus 200-, and minus 325-mesh fused and special dense oxides have been cold pressed. These compacts will be pressure bonded and evaluated on the basis of final density and structural uniformity in order to determine the optimum mixture and particle sizes for minimizing bridging effects of the oxide during pressure bonding.

Flash roasting of a series of fused uranium dioxide powders to attain off stoichiometry has been completed. Powders were roasted for 5 min at temperatures ranging from 400 to $700 \mathrm{~F}$. The resulting oxygen/uranium ratios attained in these tests have not been determined to date.

\section{Gas-Pressure Bonding}

S. J. Paprocki, S. W. Porembka, E. S. Hodge, and C. B. Boyer

The fabrication of small rod, tube, and flat-plate elements and flat-plate assemblies of stainless steel-clad $\mathrm{UO}_{2}$ has been accomplished by gas-pressure bonding. By the use of high-density cores, excellent dimensional tolerances can be achieved. There are, however, problems of dimensional tolerances, shrinkage, warpage, and deformation of the cladding when low-density green-pressed $\mathrm{UO}_{2}$ or tapped powders are used as the initial core material. At present, the corrugated rod or tube design appears to be a design which shows promise for utilizing low-density cores. The development of high-density green-pressed $\mathrm{UO}_{2}$ cores has greatly minimized densification effects. Methods of improving dimensional properties of clad elements utilizing such cores are being investigated. 
An initial investigation was made of the permeation rate of helium through several distis of pressure-bonded $\mathrm{UO}_{2}$ at room temperature. The rates of permeation of helium through disks of pressure-bonded $\mathrm{UO}_{2}$ of 82 to 92 per cent theoretical density were prosably controlled by the effect of fine (macroscopic) cracks in the material. The perneability constants for the se samples are in the range of $3 \times 10^{-6} \mathrm{ml} /(\mathrm{sec})(\mathrm{cm})(\mathrm{mm})$. The permeability constant for pressure-bonded $\mathrm{UO}_{2}$ of 95.8 per cent theoretical density is estimated to be about $1 \times 10^{-10} \mathrm{ml} /(\mathrm{sec})(\mathrm{cm})(\mathrm{mm})$, as the rate of permeation is of the samie order as, or less than, the blank rate of the apparatus used. The permeability constant of this material compares reasonably well with sintered $\mathrm{UO}_{2}$ of 90 to 93 per cent density $\left[3 \times 10^{-9} \mathrm{ml} /(\mathrm{sec})(\mathrm{cm})(\mathrm{mm})\right]$. This would indicate that the diffusion paths of the gas in this material were of microscopic dimensions.

Four samples of gas-pressure-bonded $\mathrm{UO}_{2}$ measuring $0.625 \mathrm{in}$. in diameter by 2. $242 \mathrm{in.}$ long have been submitted for a thermal-conductivity determination. Two of the samples contained Mallinckrodt high-fired $\mathrm{UO}_{2}$ (minus 400-mesh), while the other two contained a mixture of $75 \mathrm{w} / \mathrm{o}$ special dense (as received) and $25 \mathrm{w} / \mathrm{o}$ ceramic grade (as received) $\mathrm{UO}_{2}$. The tubes contairing these green-pressed cores (72. 1 to 74. 2 per cent theoretical density) were pressure bonded at $2100 \mathrm{~F}$ for $3 \mathrm{hr}$ at $10,000 \mathrm{psi}$ and rerun at $2300 \mathrm{~F}$ for $3 \mathrm{hr}$ at $10,000 \mathrm{psi}$. After bonding, the densities of the samples of 1 igh-fired $\mathrm{UO}_{2}$ were 92 to 95 per cent of theoretical, while the samples containing the mixture of $75 \mathrm{w} / 0$ special dense and $25 \mathrm{w} / 0$ ceramic grade $\mathrm{UO}_{2}$ exhibited a density of $c 5$ per cent of theoretical after bonding. Because of present demands on the thermalconductivity apparatus, it will require several months to complete the thermalconductivity tests.

Three tubes containing cold-pressed Type 304L stainless steel cores with theoretical densities of 78,82 , and 88 per cent have been pressure bonded at $2100 \mathrm{~F}$ for $3 \mathrm{hr}$ at $10,000 \mathrm{psi}$. These specimens are in the process of being evaluated for use as end plugs and spacers in tube-type elements. The starting and final densities of these stainless steel powdered components will be matched with those of the greenpressed $\mathrm{UO}_{2}$ cores to yield a smooth compartmentalized rod.

A large edge-welded stainless steel-clad $\mathrm{UO}_{2}$ compartmentalized flat plate was pressure bonded to demonstrate size feasibility. The Type 304 stainless steel components were machined from 10 - and $100-$ mil as-rolled sheet. The $\mathrm{UO}_{2}$ cores were sintered to a high initial density to minimize deformation. The 0.120 by $3-5 / 32$ by 13-15/16-in. plate contained nine cores measuring 0.100 by 0.2495 by 1.500 in. Preliminary examination of the bonded specimen revealed good dimensional control.

Further work will concern a more complete evaluation of both the fuel-element des.gns selected for pressure bonding and the pressure-bonded $\mathrm{UO}_{2}$. 


\title{
DEVELOPMENT OF URANIUM CARBIDE (AEC-FUEL, CYCLE)
}

F. A. Rough and W. Chubb

\begin{abstract}
Alternate Fabrication Methods for UC . . . . . . . . . . . F-2 Melting and Casting Techniques for Uranium-Carbon Alloys . . . . F-4 Mechanical and Physical Properties of Uranium Monocarbide. . . . F-5 Uranium Monocarbide Diffusion Studies . . . . . . . . . . F-7 Irradiation Effects in UC . . . . . . . . . . . . . . . . F-8
\end{abstract}

The preparation and properties of refractory reactor fuels of the uranium monocarbide type are being investigated at Battelle as a portion of the AEC Fuel-Cycle Develo oment Program. Studies ranging from the chemical synthesis of uranium carbide to the jhysical mechanism of neutron damage to uranium carbide are in progress. Data with respect to the densification and sintering of UC powders, the variation of density, resistivity, and strength with composition, the compatibility of UC with metals and corrosive media, and the rates of interdiffusion of uranium and carbon in the carbides have been reported in past months. More recently, it has been found possible to melt and cast uranium carbide shapes weighing up to $5 \mathrm{~kg}$, and alloys have been prepared which are both stronger and more corrosion resistant than any binary uranium-carbon alloy.

During the last month, work on hot pressing of uranium monocarbide has produced compacts which apparently have densities in excess of 95 per cent of theoretical. Hot pressing is accomplished at $1320 \mathrm{C}$ at a hydrostatic pressure of 10,000 psi. The pressure is applied to the compact by gas pressure applied to the outside of a thin-walled box or cylinder of tantalum or niobium. Under these conditions, reaction has been observed between tantalum and $\mathrm{UC}$ within $3 \mathrm{hr}$ at $1320 \mathrm{C}$. No reaction has been observed between $\mathrm{UC}$ and niobium in $3 \mathrm{hr}$ at $1150 \mathrm{C}$, and this metal will be used for tests at the higher temperature in the near future.

Data have been obtained which show that the strength of uranium monocarbide can be increased by a factor of about three times by small alloy additions. Certain other allor additions reduce the corrosion rate of uranium monocarbide in Santowax $R$ by $a$ factisr of about five times. One alloy showed no weight loss after a 24-hr exposure in saturated water vapor at $45 \mathrm{C}$. This method of improving the properties of uranium carkides is being actively pursued, since one of the major shortcomings of uranium carkides is their tendency to react with moist air and water. 
Alternate Fabrication Methods for UC

S. J. Paprocki, D. L. Keller, D. E. Kizer,

J. M. Fackelmann, and E. O. Speidel

Various methods of preparing UC powder and economical techniques for its consolidation to high-density UC bodies are being investigated.

Uranium carbide powder with 4.81 w/o total carbon, $1.1 \mathrm{w} / .0$ free carbon, has been prepared by passing methane at a rate of $5 \mathrm{ft}^{3}$ per hr over uranium powder at a temperature of $700 \mathrm{C}$. Flowing methane was passed over uranium hydride powder at a temperature of $200 \mathrm{C}$ before slowly heating the reaction tube to $700 \mathrm{C}$. The methane was allowed to flow over the uranium powder for $2 \mathrm{hr}$ at a temperature of $700 \mathrm{C}$. The flow of methane was then stopped, and the pressure was slowly reduced to a vacuum before admitting $1 \mathrm{~atm}$ of hydrogen and then cooling to $200 \mathrm{C}$ to hydride the unreacted uranium. Methane was then allowed to flow over the powder at a rate of $5 \mathrm{ft}^{3}$ per hr while the temperature was raised to $700 \mathrm{C}$, where it was maintained for $1 \mathrm{hr}$ before once again evacuating the vessel, admitting a partial pressure of hydrogen, and cooling to $200 \mathrm{C}$. This process was repeated until no further reaction occurred with hydrogen at $200 \mathrm{C}$. The total reaction time at $700 \mathrm{C}$ was $6 \mathrm{hr}$. The powder obtained by this procedure will be further evaluated by $X$-ray analyses and by a study of its sinterability.

A pellet having a green density $7.44 \mathrm{~g}$ per $\mathrm{cm}^{3}$ as pressed from UC powder of $4.8 \mathrm{w} / \mathrm{o}$ carbon has been compacted in a tantalum tube for $3 \mathrm{hr}$ at $1320 \mathrm{C}$ under a helium pressure of $10,000 \mathrm{psi}$. Microscopic examination of the UC product indicated a density of 95 per cent of theoretical or greater. A layer of tantalum carbide formed at the corecladding interface which depleted the carbon content of the UC sufficiently to form a thin uranium matrix at the UC grain boundaries. Additional UC green compacts are being prepared for hot pressure compacting in carburized tantalum tubing in an attempt to prevent the decarburization of the UC. In addition, a similar low-density UC core has been hot-pressed in a niobium tube for $3 \mathrm{hr}$ at $1150 \mathrm{C}$ at a helium pressure of 10,000 psi. Microscopic examination of the product indicated that little or no densification occurred at this temperature; however, no reaction was noted between the niobium and UC. Additional UC powder compacts are being prepared for pressure bonding in niobium tubes at higher temperatures.

Metallographic examinations of various types of uranium carbide compacts cold pressed at 40 to $50 \mathrm{tsi}$ and sintered in the vicinity of $1900 \mathrm{C}$ in vacuum have been completed. Approximate average and maximum grain sizes observed in the sintered compacts are tabulated in Table F-1.

The powder produced from the uranium-propane reaction exhibited a grain growth of many magnitudes in all cases with a corresponding reduction in porosity, as determined microscopically. Nonuniform grain size occurred when decarburization of UC at the surface of the compact resulted in the formation of a rim containing more uranium in the grain boundaries than could be detected in the core of the compact. This situation occurred in the thicker compacts and is believed to be due to reaction of UC with oxygen present in the 0.05- $\mu$ dynamic vacuum. Under these conditions uranium forms in the grain boundaries, and rapid sintering, grain growth, and densification occur, retarding further oxygen penetration to the center of the core. Only uranium and UC were observed, and the uranium was present as a continuous grain-boundary network and as fine spheroids within the grains. Where grains had grown to an average size of $200 \mu$, 
TABLE F-1. SUMMARY OF DATA ON VACUUM-SINTERED URANIUM CARBIDE COMPACTS

\begin{tabular}{|c|c|c|c|c|c|c|c|c|c|c|c|}
\hline \multirow{3}{*}{$\begin{array}{c}\text { Average } \\
\text { Powder } \\
\text { Particle Size, } \mu\end{array}$} & \multirow{2}{*}{\multicolumn{2}{|c|}{$\begin{array}{c}\text { Oxygen Content, } \\
\mathrm{ppm}\end{array}$}} & \multirow{2}{*}{\multicolumn{2}{|c|}{$\begin{array}{c}\text { Carbon Content, } \\
\text { w/o }\end{array}$}} & \multicolumn{2}{|c|}{ Sintering Conditions } & \multirow{2}{*}{\multicolumn{2}{|c|}{ Grain Size, }} & \multirow{3}{*}{$\begin{array}{l}\text { Microscopic } \\
\text { Density, } \\
\text { per cent }\end{array}$} & \multicolumn{2}{|c|}{ Measured Density } \\
\hline & & & & & \multirow{2}{*}{$\begin{array}{c}\text { Time, } \\
\mathrm{hr}\end{array}$} & \multirow{2}{*}{$\begin{array}{c}\text { Temperature, } \\
\mathrm{C}\end{array}$} & & & & \multirow[b]{2}{*}{$G$ per $\mathrm{Cm}^{3}$} & \multirow{2}{*}{$\begin{array}{r}\text { Per Cent }{ }^{(a)} \text { o } \\
\text { Theoretical }\end{array}$} \\
\hline & Powder & Sintered & Powder & Sintered & & & Average & Maximum & & & \\
\hline \multicolumn{12}{|c|}{ Powder Prepared by Uranium-Propane Reaction } \\
\hline \multirow[t]{4}{*}{8} & 5600 & -- & 4.68 & 4.37 & 1 & 1900 & 40 & 327 & 80 & 11.4 & 81.7 \\
\hline & & -- & 4.68 & - & 2 & $1910(\mathrm{~b})$ & 220 & (c) & 95 & 12.0 & -- \\
\hline & & -- & 4.68 & -- & 1 & 1920 & 50 & 200 & 90 & 10.5 & -- \\
\hline & & 1730 & 4.68 & 4.17 & 1 & 1950 & 250 & 350 & 95 & (d) & -- \\
\hline \multicolumn{12}{|c|}{ Powder Prepared by Uranium-Methane Reaction } \\
\hline \multirow[t]{4}{*}{12} & 6900 & -- & 5.98 & 4.61 & 1 & 1900 & 15 & 25 & 75 & 11.0 & 79.9 \\
\hline & & -- & 5.98 & -- & 2 & $1910^{(\mathrm{Dj})}$ & 180 & (c) & 95 & 11.8 & -- \\
\hline & & - & 5.98 & -- & 1 & 1920 & 35 & 180 & 85 & 11.9 & -- \\
\hline & & 1540 & 5.98 & 4. 32 & 1 & 1950 & 40 & 125 & 85 & 11.2 & 80.0 \\
\hline \multicolumn{12}{|c|}{ Powder Prepared by Crushing Arc-Melted UC } \\
\hline \multirow[t]{2}{*}{25} & 1200 & -. & 4.83 & 4.66 & 1 & 1900 & 35 & (c) & 70 & 9.9 & 71.9 \\
\hline & & 1400 & 4.83 & 4.37 & 1 & 1950 & 50 & 125 & 80 & 11.2 & 80.2 \\
\hline
\end{tabular}

(a) Based on the theoretical density of an alloy having the carbon content of the sintered compact.

(b) Temperature dropped from $1970 \mathrm{C}$ to. $1850 \mathrm{C}$ during the experiment.

(c) No significant variation from average.

(d) No measurement possible. 
apparently isolated round pores were present in the central portion of the grains, and densities were estimated to be 95 per cent of theoretical, or more. These density measurements based on microscopic examination give a more accurate picture of the densification than do measured densities. Measured densities were obtained from weights and physical dimensions, and since many specimens were cracked, apparent densities were low. The measured and microscopic densities are shown in Table F-1. In all cases, neck growth had progressed substantially and equiaxed grains were present in the core as well as in the rim. It appears that $1920 \mathrm{C}$ is about the minimum sintering temperature required for core and rim densities of 90 per cent of theoretical for this propaneproduced powder.

Grain growth and densification of the methane-produced powder were less rapid than for the propane-produced powder for each condition studied, although the structural characteristics discussed above were equally true for compacts made from the methaneproduced powder. Density and grain-size values are tabulated in Table F-1. The 180- $\mu$ grain size and 95 per cent microscopic density obtained by sintering $2 \mathrm{hr}$ at $1910 \mathrm{C}$ were due to a complete formation of uranium grain boundaries throughout the 80-mil-thick compacts. For a larger compact a maximum density of 85 per cent of theoretical was obtained after $1 \mathrm{hr}$ at $1950 \mathrm{C}$.

In comparing results for these two powders it is significant to note that the particle size and carbon content of the methane-produced powder were greater than for the propane-produced powder (12 compared with $8 \mu$ in diameter and 5.98 compared with $4.68 \mathrm{w} / 0$ carbon). Powders having low carbon contents and a fine particle size have been found to densify more readily. The particle-size effect is further exemplified by the low densities obtained with the relatively coarse (25 $\mu$ in diameter) arc-melted and crushed UC.

It is interesting to examine carbon and oxygen contents before and after sintering, as listed in Table F-1. It is apparent from the results that oxygen is removed from the compacts initially high in oxygen, probably due to reaction with free carbon and UC, and, furthermore, that the compacts did not contain enough oxygen to account for the losses in carbon content observed. Since no $\mathrm{UO}_{2}$ was observed in the sintered compacts, it is likely that the 1400 to $1700 \mathrm{ppm}$ of residual oxygen was dissolved in the UC lattice.

An effort is being made to reduce sintering temperatures and to eliminate grainboundary uranium. Chromium additions and an argon atmosphere are being studied with these objectives in mind. Preliminary indications are that these approaches are promising.

Melting and Casting Techniques for Uranium-Carbon Alloys

B. C. Boesser, W. M. Phillips, E. L. Foster, and R. F. Dickerson

Reliable techniques for the production of high-quality cast shapes of uranium carbide are being developed. Efforts to prepare and improve the quality of large cast shapes of skull-type arc-melted uranium carbide are in progress. Sound, homogeneous uranium carbide castings can now be produced with composition control on the order of $\pm 0.3 \mathrm{w} / \mathrm{o}$ carbon from ingot to ingot. 
During the past month several 3/4-in. - round by 8 -in. -long and 1 -in. by 6 -in. -long cast shapes were produced with compositions ranging from 4.6 to 5.1 w/o carbon. Gas analyses by vacuum-fusion techniques of one of the 3/4-in.-diameter castings showed $107 \mathrm{ppm}$ of oxygen and $1 \mathrm{ppm}$ of hydrogen in this typical casting. It was found that castings containing less than $4.8 \mathrm{w} / \mathrm{o}$ carbon adhered to graphite molds heated to $2200 \mathrm{~F}$. Evidently a reaction occurs between the free uranium metal existing in low-carbon alloys and :he hot graphite which makes it difficult to remove the casting without breaking the molcl. This difficulty is not observed when using a cold graphite mold.

In an attempt to further minimize compositional variations caused by inhomogeneity in the large $80-\mathrm{kg}$ skull, a smaller crucible that will hold a $40-\mathrm{kg}$ skull, but which is otherwise similar in design, has been installed in the skull-type arc furnace. This skull is boing prepared in the new crucible from prealloyed uranium carbide rather than from elemiental materials. It is expected that the new skull will improve composition control in acldition to being easier to handle.

Research during the next month will be concerned with evaluating the new skull and with further attempts to improve the composition control of uranium carbide castings. Studies mentioned last month of the effects of melting time and atmosphere on electrode tip-crosion and on the impurity content of the cast shapes will be resumed. Techniques will also be studied to increase the quantity of material that can be produced in the skulltype arc furnace in a given time.

\section{Mechanical and Physical Properties} of Uranium M.Tonocarbide

W. M. Phillips, E. L. Foster, and R. F. Dickerson

The present study of uranium carbide is concerned with the definition and improvement of its properties and those of its alloys. Such variables as impurity content, carkion content, and heat treatment are being evaluated on the basis of their effects on the density, rupture strength, electrical resistivity, thermal conductivity, and corrosion resistance of uranium carbides. Past work has indicated that both strength and corrosion resistance can be improved by additions of metal or metal carbides to uranium monocarbide. During the past month further studies of the effects of these additions were undertaken.

Additions of molybdenum, $\mathrm{Mo}_{2} \mathrm{C}$, niobium, $\mathrm{NbC}$, titanium, $\mathrm{TiC}$, vanadium, and VC Nere made to UC to give nominal compositions of $1,5,10$, or $20 \mathrm{w} / 0$ of each of the allor additions. Using the drop-casting technique, well-formed, sound castings were obtained of all alloys with the following exceptions: UC plus $10 \mathrm{w} / 0$ molybdenum, titaniun, niobium and $20 \mathrm{w} / 0 \mathrm{Mo}_{2} \mathrm{C}, \mathrm{TiC}$, and $\mathrm{IbC}$. Transverse rupture- and compressivestrength tests were run on these castings. The metal additions produced a larger strength increase than did the carbide additions. Additions of $5 \mathrm{w} / 0$ metal increased both the compressive and transverse rupture strength of uranium carbide by a factor of about three times. This is illustrated by the data in Table $F-2$. 
TABLE F -2. EFFECT OF ALLOYING ON THE RUPTURE STRENGTH OF URANIUM MONOCARBIDE

\begin{tabular}{lcc}
\hline \hline $\begin{array}{c}\text { Alloy Nominal } \\
\text { Composition, w/o }\end{array}$ & $\begin{array}{c}\text { Compressive } \\
\text { Rupture Strength, } \\
\text { psi }\end{array}$ & $\begin{array}{c}\text { Transverse } \\
\text { Rupture Strength, } \\
\text { psi }\end{array}$ \\
\hline UC & 50,000 & 10,000 \\
UC-5 Mo & 140,000 & 30,000 \\
UC-5 Mo ${ }_{2} C$ & 110,000 & 30,000 \\
UC-5 Nb & 200,000 & 30,000 \\
UC-5 NbC & 25,000 & 12,000 \\
UC-5 Ti & -- & 30,000 \\
UC-5 TiC & 60,000 & 20,000 \\
UC-5 V & 140,000 & 40,000 \\
UC-5 VC & 50,000 & 25,000 \\
\hline \hline
\end{tabular}

Corrosion tests of each of the specimens were run in Santowax R, saturated water vapor, and dry air. The corrosion rate was reduced more by the addition of the carbides than by the metals. Within the limits of experimental error, it appears that corrosion rates decreased with increasing amounts of alloy carbide. The tests were made on both annealed and as-cast alloys. Annealing for $1 \mathrm{hr}$ at $1800 \mathrm{C}$ caused an increase in the corrosion rate by a factor of approximately two. The results of the corrosion tests are summarized in Table $F-3$.

TABLE F -3. EFFECT OF ALLOY CONTENT ON THE CORROSION RESIST ANCE OF CAST URANIUM MONOCARBIDE

\begin{tabular}{|c|c|c|c|}
\hline \multirow[b]{2}{*}{$\begin{array}{l}\text { Alloy Nominal } \\
\text { Composition, w/o }\end{array}$} & \multicolumn{3}{|c|}{$\begin{array}{c}\text { Corrosion-Rate, Weight Loss(a), } \\
\mathrm{mg} /\left(\mathrm{cm}^{2}\right) \text { (day) }\end{array}$} \\
\hline & $\begin{array}{c}\text { In Santowax R } \\
\text { at } 350 \mathrm{C}\end{array}$ & $\begin{array}{c}\text { In Water Vapor } \\
\text { at } 45 \mathrm{C}\end{array}$ & $\begin{array}{l}\text { In Dry Air } \\
\text { at } 300 \mathrm{C}\end{array}$ \\
\hline UC & 0.40 & s & $S$ \\
\hline $\mathrm{UC}-5 \mathrm{Mo}_{2} \mathrm{C}$ & 0.04 & 76.0 & 3.37 \\
\hline $\mathrm{UC}-10 \mathrm{Mo}_{2} \mathrm{C}$ & 0.13 & 0 & 0.74 \\
\hline $\mathrm{UC}-5 \mathrm{NbC}$ & 1.53 & S & 6.5 \\
\hline $\mathrm{UC}-10 \mathrm{NbC}$ & $+0.15^{(b)}$ & -- & -. \\
\hline UC-5 TiC & 0.20 & 70.9 & 31.9 \\
\hline $\mathrm{UC}-10 \mathrm{TiC}$ & 0.10 & 28.3 & 2.45 \\
\hline UC-5 VC & 0.08 & 270.0 & 3.58 \\
\hline UC-10 VC & 0.07 & 21.9 & 19.9 \\
\hline
\end{tabular}

(a) Code:

$0=$ no detectable weight loss in $24 \mathrm{hr}$

$\mathrm{S}=$ specimen shattered.

(b) Gained weight.

Because of the favorable results obtained in these initial studies on alloying of the monocarbide of uranium, additional studies are being undertaken on the effects of other alloy additions. Additional specimens of uranium carbides containing the alloy additions listed in Tables F-2 and F-3 are being prepared for further study. Studies of the compatibility of UC with various metals at 800 and $900 \mathrm{C}$ are in progress to supplement the data obtained earlier at 1000 and $1200 \mathrm{C}$. A study of the effects of handling and storage upon the mechanical properties of uranium carbide has been initiated. 
$\underline{\text { Uranium Monocarbide Diffusion Studies }}$

W. Chubb, R. W. Getz, and F. A. Rough

Diffusion rates in uranium monocarbide are of interest in estimating the characteristics of this material at elevated temperatures. Such characteristics as creep strength and resistance to radiation damage are related to diffusion rates and are of interest since this material is being considered as a nuclear fuel for high-temperature ope:ation. Previously in the study, the rate of interdiffusion of carbon and uranium was determined between 1600 and $2000 \mathrm{C}$ using graphite and liquid uranium saturated witl. carbon. Currently, the rate of self-diffusion of uranium in uranium monocarbide is keing studied using a tracer technique involving uranium-235 as a tracer. The uraniur enrichment is determined by gross-garnma counting of samples taken at 0.00l-in. intervals along the diffusion-annealed specimens. These analyses indicate that the selfdiffusion coefficient for uranium in uranium monocarbide is from 100 to 1000 times less thar the interdiffusion coefficient determined previously. Additional diffusion couples are being prepared and evaluated.

In the current study, diffusion couples are prepared by placing a $0.001-$ in. - thick metal foil of enriched uranium (93 per cent uranium-235) between two 0.25-in. lengths of depleted uranium (0.04 per cent uranium-235) monocarbide rod. Preparation of the coujles for annealing involves wrapping the couple in tantalum foil and placing it in a degissed graphite jig for a bonding at $1400 \mathrm{C}$ for $4 \mathrm{hr}$. After diffusion annealing at a higher temperature, the couple is sampled for gross-gamma counting for uranium- 235 content by grinding the couple on 600-grit silicon carbide powder in the presence of a small amount of $0.1 \mathrm{~N}$ nitric acid solution to remove slices approximately 0.001 in. thick.

Using the gross-gamma counting method of analysis, self-diffusion coefficients for urajiium in uranium monocarbide have been calculated for four diffusion couples. The resilts do not show any consistent trend with respect to the variation of the self-diffusion coe:ficient with temperature. The results obtained are as follows:

\begin{tabular}{cc}
$\begin{array}{c}\text { Temperature, } \\
\text { C }\end{array}$ & $\begin{array}{c}\text { Self-Diffusion } \\
\text { Coefficient, } \\
2\end{array}$ \\
\hline 1800 & $\frac{\mathrm{cm}^{2} \text { per sec }}{3 \times 10^{-9}}$ \\
1900 & $1 \times 10^{-9}$ \\
2000 & $1 \times 10^{-8}$ \\
2100 & $3 \times 10^{-9}$
\end{tabular}

A couple annealed for $1440 \mathrm{~min}$ at $1800 \mathrm{C}$ has been prepared and examined metallographically. The couple appears to be satisfactorily bonded and will be sampled for analysis for uranium-235 content.

Future work will include the preparation and analysis of additional diffusion cou'sles. 


\title{
Irradiation Effects in UC
}

\author{
A. E. Austin, D. G. Freas, C. M. Schwartz, \\ and F. A. Rough
}

The changes in structure and physical properties of UC with irradiation are being investigated. The irradiation of two capsules containing natural UC specimens has been started. These capsules will be irradiated for one and three BRR cycles, respectively, to produce estimated burnups of 0.01 and $0.03 \mathrm{a} / \mathrm{o}$ of uranium. The specimens are contained in $\mathrm{NaK}$ in order to maintain a temperature of about $180 \mathrm{~F}$ in the center of the specimens.

The preirradiation examination of these specimens has been completed. The irradiation of these capsules is expected to be completed early in May, and the capsules will then be transferred to the Battelle Hot-Cell Facility for examination of the specimens.

Additional irradiation experiments are planned to include specimens of $\mathrm{UC}+\mathrm{UC}_{2}$ and also $\mathrm{UC}+\mathrm{U}_{2} \mathrm{C}_{3}$. The composition of these specimens will be about $5.0 \mathrm{w} / 0$ carbon. Also, specimens near the compositions of $\mathrm{UC}_{2}$ and $\mathrm{U}_{2} \mathrm{C}_{3}$ are to be irradiated. These irradiations will be conducted at both low and high temperatures for burnups of up to 1 a/o uranium.

Supporting experiments for these irradiations are planned, including study of heat treatment and compatibility to be conducted on natural-uranium specimens. These supporting experiments will provide a basis for selecting the proper heat treatments and for interpretation of changes that are observed after irradiation. An example of the changes to be interpreted is the disappearance of the $\mathrm{UC}_{2}$ second phase in hyperstoichiometric UC during irradiation.

Electron micrographs of material where this disappearance of $\mathrm{UC}_{2}$ occurred have been obtained. These micrographs were made from a specimen that contained $5.0 \mathrm{w} / \mathrm{o}$ carbon and was irradiated to a 1.8 a/o burnup of the uranium. Platelets of $\mathrm{UC}_{2}$ were present in the UC matrix of this specimen. After the irradiation at about $1200 \mathrm{~F}$, there was no $\mathrm{UC}_{2}$ observed in the specimen center, but the electron micrographs showed the presence of a fine precipitate, 0.1 by $1 \mu$, etched in relief, in an amount estimated to be between 1 to 2 volume per cent. It is suggested that this precipitate may be graphite produced by decomposition of the $\mathrm{UC}_{2}$. Further work is necessary to test this hypothesis. The electron micrographs also showed partially decomposed $U_{2}$ platelets near the specimen edges.

Work is proceeding on preparation of enriched UC specimens for ir radiation to higher burnups. 
PHYSICAL RESEARCH (AEC-DR)

F. A. Rough

Thermal Migration of Hydrogen in Zirconium . . . . . . . . . G-2

Fusion Methods to Prepare Single Crystals of $\mathrm{UO}_{2}$. . . . . . . G-2

Growth of $\mathrm{UO}_{2}$ Crystals From the Vapor Phase . . . . . . . . G-3

Experiments are being conducted under a one-dimension temperature gradient to study the movement of hydrogen in a special zirconium hydride diffusion cell. At the monient, the diffusion cell, which proved to be defective, is being replaced.

Promising results are being obtained on the growth of $\mathrm{UO}_{2}$ single crystals. For exarnple, a dendritic crystal weighing $1.58 \mathrm{~g}$ has been grown by deposit from vapor by reacting uranium fluoride and water. These and other fusion-type experiments are being continued. 
Thermal Migration of Hydrogen in Zirconium

J. W. Droege and H. H. Krause

The effect of a thermal gradient on the distribution of hydrogen in zirconium is being examined. Diffusion coefficients for hydrogen in the beta and delta hydride phases have been determined as a function of temperature and composition. Data on the beta-phase study were reported in BMI-1373 and those for the delta phase were published recently as $B M I-1426$. The results show that the diffusion is strongly temperature dependent, but is not affected significantly by composition, within a given phase. These data will be used in conjunction with the results of the thermal-gradient experiments to establish a theoretical basis for prediction of hydrogen migration.

In the thermal-gradient study, the diffusion cell has been incorporated in the vacuum system and placed in the gradient furnace. Calibration experiments were conducted at constant temperature and also with a one-dimensional gradient. However, mechanical failure in the diffusion element has limited the amount of data on diffusion that can be obtained with this particular unit. Another element is now in the process of fabrication, and will be substituted for the one presently in use. Diffusion experiments will then be continued to determine the effects of the thermal gradient on the movement of hydrogen in the hydride.

Fusion Methods to Prepare Single Crystals of $\mathrm{UO}_{2}$

W. P. Allred, J. D. Jackson, and B. Paris

Research on growth of crystals of $\mathrm{UO}_{2}$ during March was concentrated on the horizontal zone-melting method. The apparatus used consists of a horizontal tungsten tube which is heated by an a-c current from a low-voltage high-amperage current supply. A hot zone is produced by a tantalum radiation shield which can be moved along the tube to form a traveling molten zone. The tungsten tube is used as a crucible and also provides the energy for melting. Uranium dioxide has been melted in this system. Unfortunately, the window clouded with the evaporation and condensation of higher oxides of uranium, and the system was heated above the melting point of $\mathrm{UO}_{2}$. An $\mathrm{Al}_{2} \mathrm{O}_{3}$ shield surrounding the tungsten tube melted, and the system was cooled down rather quickly.

The evaporated $\mathrm{UO}_{2}$ and the fast freezing of a small liquid section of the ingot showed very interesting results. The $\mathrm{UO}_{2}$ crystallites which apparently were grown from the vapor were transparent and red in color, indicating that considerable purification occurred in the process of sublimation and crystal growth. The largest of these crystallites were about 0.01 in. in diameter. Some appeared to be nearly perfect cubic crystals. Extensive crystal growth was observed in the section where melting occurred. The largest of the se crystals was about $0.5 \mathrm{~cm}$ across the surface. The large crystal growth obtained is very encouraging. Refinements of the apparatus and better control of the temperature should provide further positive results.

In another experiment crystals were grown near the melting point of $\mathrm{UO}_{2}$ and apparently deposited from the vapor directly on the surface of the $\mathrm{UO}_{2}$ charge. These 
crystals were mostly opaque, although some sections appeared transparent. Evidently the oxygen content was too high in the opaque crystals. Crystal platelets as large as $1 / \varepsilon$ in. in surface area were obtained in this experiment. The current experiments and plans include concentration on the horizontal zone-purification work.

\section{Growth of $\mathrm{UO}_{2}$ Crystals From the Vapor Phase}

C. A. Alexander and R. B. Filbert, Jr.

Research has continued on growing single crystals of $\mathrm{UO}_{2}$ from the reaction

$$
\mathrm{UF}_{4}(\mathrm{~g})+2 \mathrm{H}_{2} \mathrm{O}(\mathrm{g}) \rightarrow \mathrm{UO}_{2}(\mathrm{c})+4 \mathrm{HF}(\mathrm{g}) \text {. }
$$

From the experiments made this month and in past months at $1050 \mathrm{C}$, it is concluded that crystals in the millimeter size range can be grown consistently. Conditions unde which larger crystals may be grown are under investigation.

Microscopic examination of the single crystals indicates that in larger crystals growth around the edges proceeds faster than in the center, leaving troughs in the certer of the faces. Current runs are being conducted at low growing rates to determine if a lower rate will eliminate this effect. In one such low-growth-rate run, the major crystalline form was dendritic with dentrites $26 \mathrm{~mm}$ in length. One such dendritic growth measured 26 by 13 by $3 \mathrm{~mm}$ and weighed $1.58 \mathrm{~g}$.

In an effort to observe growth rates and patterns, a new apparatus was constructe which would allow insertion of a window. Unfortunately, this new apparatus requires a vertical charge holder and is probably less efficient than the apparatus previously used, but it is hoped that the added benefit of visual observation will compensate for the smaller charge-surface area.

It is planned to continue experiments with the $\mathrm{UF}_{4}-\mathrm{H}_{2} \mathrm{O}$ reaction during the coming moith and to attempt to observe the growth process of the crystals under different conditions of water-vapor flow, partial pressure, and system temperature. 


\title{
RADIOISOTOPE AND RADIATION APPLICATIONS (AEC-OID)
}

\author{
D. N. Sunderman
}

\begin{abstract}
Development of Radioactive-Tracer Quality-Control Systems . . . H-2 Use of Intrinsic Radioactive Tracers for Process Control . . . . H H Graft-Polymerization Studies . . . . . . . . . . . . . H-4 Nitration of Hydrocarbons . . . . . . . . . . . . . . . $\mathrm{H}-5$
\end{abstract}

Four research programs in the area of radioisotope and radiation applications are under way for the Office of Isotopes Development. These programs include the development of radioactive-tracer quality-control systems, the use of intrinsic radioactive tracers for process control, the study of radiation-induced graft polymerization, and the nitration of hydrocarbons.

The determination of sulfate in portland cement is very important to the control of the manufacturing process. Since currert techniques are quite time consuming, the development of a radiometric method was undertaken. The basis of the method is the precipitation of strontium sulfate tagged with strontium-89 from an acetone-water solution, with radioassays performed before and after precipitation. Results to date ind cate an accuracy on the order of \pm 1 per cent can be obtained.

Construction of the equipment for obta.ining engineering data on the use of intrinsic radioactive tracers in the iron-removal step in a nickel-refining process is well under way and should be completed within 1 month. Survey of hydrometallurgical applications of intrinsic tracer control has pointed up possibilities in a variety of processes. The stuily of tracer control of urit operations in general is also continuing.

A variety of ester-substituted methacrylates, polymerized under carefully controlled conditions to minimize monomer content, are being irradiated, and the degradat on products are being determined. Cur ent experimental results should be available for inclusion in next month's report.

A series of experimental runs was made to determine the effect of ionizing radiatior upon the nitration of cyclohexane, using $\mathrm{NO}_{2}$ as the nitrating agent. Results indicat 2 that the identity of the products and their yields were substantially the same as tho se obtained in the nitric acid experiments. The radiation effects were of very minor imfrortance. Since April 1, 1960, is the end of the contract period, experimental work has been discontinued, and a topical report is being prepared. 


\section{Development of Radioactive-Tracer Quality- Control Systems}

R. Lieberman, C. W. Townley, R. A. Ewing, and D. N. Sunderman

The objective of current work is to develop a radiometric method for the determination of sulfate in portland cement. Precipitation of $\mathrm{Ba}^{140} \mathrm{SO}_{4}$ has been proposed for this analysis. However, difficulties arise because its lanthanum-140 daughter forms a moderately soluble sulfate. Among other sulfates one of the least soluble is strontium sulfate. Strontium-89, a beta emitter with a 53-day half-life, is conveniently available and appeared to offer promise as a radioactive tracer for sulfate analysis.

The use of strontium-89 tracer was investigated in a series of experiments in which standardized potassium sulfate solutions were reacted with strontium nitrate tagged with strontium-89.

The radioactivity of the strontium-89 nitrate was measured initially, and the radioactivity of the supernatant was again measured after precipitation of strontium sulfate. The quantity of sulfate present was calculated from the difference in radioactivity using the following equation:

$$
\frac{A_{i}-A_{f}\left(\frac{V_{f}}{V_{i}}\right)}{A_{i}} \times M_{S r}^{+2}=M_{S O_{4}}^{-2},
$$

$A_{i} \quad=$ initial counting rate

$A_{f} \quad=$ final counting rate

$\mathrm{V}_{\mathrm{i}} \quad=$ initial volume

$\mathrm{V}_{\mathrm{f}} \quad=$ final volume

$\mathrm{MSr}_{\mathrm{Sr}}^{+2}=$ number of moles of strontium initially present

$\mathrm{M}_{\mathrm{SO}_{4}}^{-2}=$ number of moles of sulfate present.

Difficulties were initially encountered with incomplete precipitation of the strontium sulfate in water and alcohol-water mixtures. Later experiments were carried out successfully using a mixture of $75 \mathrm{ml}$ of acetone and $22 \mathrm{ml}$ of water. The acetone was added to a reaction flask followed by $12 \mathrm{ml}$ of strontium-89 nitrate $(0.0229 \mathrm{M})$. An aliquot of the mixture was removed and radioassayed. The aliquot was returned to the mixture and $10 \mathrm{ml}$ of potassium sulfate $(0.0177 \mathrm{M})$ was added to the flask. The contents were stirred and digested on a steam bath for $10 \mathrm{~min}$.

Evaporation of solvent was prevented by using a short reflux condenser. After digestion, the reaction mixture was cooled to room temperature. Approximately $60 \mathrm{ml}$ was transferred to centrifuge cones and centrifuged for $5 \mathrm{~min}$. An aliquot of the clear supernatant was removed and radioassayed. 
The results of nine determinations are shown in Table $\mathrm{H}-1$.

TABLE H-1. RESULTS OF SULFATE DETERMINATIONS

\begin{tabular}{|c|c|c|c|c|c|}
\hline \multirow[b]{2}{*}{ Dete:mination } & \multicolumn{2}{|c|}{ Radioactivity, cpm } & \multicolumn{2}{|c|}{ Total $\mathrm{K}_{2} \mathrm{SO}_{4}$, millimole } & \multirow[b]{2}{*}{ Error, per cent } \\
\hline & Initial & Corrected Final & Found & Added & \\
\hline 1 & 12325 & 4440 & 0.176 & 0.177 & -0.57 \\
\hline 2 & 12205 & 4320 & 0.178 & 0.177 & +0.57 \\
\hline 3 & 12205 & 4350 & 0.177 & 0.177 & 0.0 \\
\hline 4 & 12205 & 4333 & 0.177 & 0.177 & 0.0 \\
\hline 5 & 11138 & 4123 & 0.173 & 0.177 & -2.3 \\
\hline 6 & 5858 & 2120 & 0.176 & 0.177 & -0.57 \\
\hline 7 & 5858 & 2108 & 0.176 & 0.177 & -0.57 \\
\hline $8^{(a)}$ & 5858 & 2208 & 0.172 & 0.177 & -2.8 \\
\hline 9 & 5858 & 2075 & 0.178 & 0.177 & +0.57 \\
\hline
\end{tabular}

(a) l'otassium sulfate added to acetone before strontium-89 nitrate.

During the coming month work will continue on a statistical series using different sulfate concentrations. Effects of interfering ions will be studied, and direct sulfate meisurements on portland cement will be attempted.

\section{Use of Intrinsic Radioactive Tracers for} Process Control

J. L. McFarling, P. Gluck, J. F. Kircher, and D. N. Sunderman

Construction of the model process system to study radiotracer control of the ironremioval step in a nickel-refining process should be completed by the end of next month. The only major equipment item not yet received is the laboratory pressure filter, which is to be shipped soon.

Study of unit operations for application of the intrinsic radiotracer technique has bee a continued this month. Emphasis has been given to a survey of the literature and an examination of each individual unit operation to determine its over-all amenability to iatrinsic radiotracer control.

The major effort this month has been in the survey of hydrometallurgical operations. All of the applications considered fall into the category of purification steps in hydrometallurgical processes. In every casse the impurity would be labeled by a radioisotope and the removal of the impurity would be followed by radioactivity meilsurements.

The processes covered so far are: the Sherritt-Gordon nickel-refining process, the Freeport Sulfur nickel-refining process, the Inco nickel electrolyte purification, and the electrolytic zinc process. Of those considered so far the following potential radiotracer-control applications appear to have the most promise: 
(1) Removal of iron in the Sherritt-Gordon process

(2) Removal of iron in the Freeport process

(3) Removal of copper in the Freeport process

(4) Removal of iron in the Inco process

(5) Removal of cadmium in the electrolytic zinc process

(6) Removal of cobalt in the electrolytic zinc process.

Future work will emphasize completion of the model iron-removal system as well as continuation of both the unit-operations study and hydrometallurgical-processes survey.

\section{Graft-Polymerization Studies}

I. S. Ungar, W. B. Gager, J. F. Kircher, and R. I. Leininger

During the past month the investigation of the mechanism of formation and decay of radiation-induced free radicals as influenced by structural factors continued. As described previously, methylmethacrylate as well as methylformate was found in irradiated polymethylmethacrylate by means of vapor-phase chromatography. This information is important since it indicates the pathway of this reaction. During the past month a similar study was made for the polybutylmethacrylates. Samples of the polymers were irradiated, and the vapors were analyzed. The data obtained are being compared with those from known compounds in an attempt to identify the fragments produced by radiation. The results of this investigation will be available in the next monthly report.

A more intensive study of the effects of molecular weight on site formation dis closed that the differences which appeared previously were within experimental error. This phase of the investigation is being discontinued until such time as polymers having a greater difference in molecular weight become available.

During the next month the investigation of radiation effects on polybutylmethacrylates will be completed. An attempt will be made to correlate the effect of branching on the ester chain with the mechanism of site formation. This will be done by comparing the products of irradiation with the decrease in molecular weight and the information obtained from electron paramagnetic resonance studies.

Information was received that a paper written for publication in the Journal of Polymer Science has been accepted. A second paper for the same publication will be completed during the next month. 
Nitration of Hydrocarbons

M. J. Oestmann, G. A. Lutz, E. J. Kahler,

and J. F. Kircher

The use of nitrogen dioxide as the nitrating agent for the radiation-induced nitratio 1 of cyclohexane was investigated during the current report period. Six irradiation ancl thermal experiments were completed with the cyclohexane-nitrogen dioxide system. Two irradiations were also conducted with the cyclohexane-nitric acid system. Analytical results are summarized in Table $\mathrm{H}-2$.

Both the $\mathrm{HNO}_{3}$ and the $\mathrm{NO}_{2}$ experiments were conducted at $60 \mathrm{C}$ employing a $10 / 1$ mole ratio of cyclohexane to nitrating agent. Using conventional vacuum techniques, $\mathrm{NO}_{2}$-cyclohexane mixtures were prepared by condensing a measured amount of purified nitrogen dioxide in a glass reaction vessel containing cyclohexane. The vessel was then sealed under vacuum. Samples were irradiated from 6 to $20 \mathrm{hr}$, corresponding to gainma doses of $1 \times 10^{6}$ to $3.8 \times 10^{6} \mathrm{rads}$.

In the $\mathrm{HNO}_{3}$-cyclohexane experiments (66 and 67), the analytical procedure used was checked to determine whether any loss of reaction products occurred during sample treatment prior to gas chromatographic analysis. After irradiation of the nitric acid-cyclohexane system, the moles of gas produced (Column 5 in Table H-2) were first determined by measuring the pressure of gas released into a known volume. After filtering off the solid adipic acid, the cyclohexane phase was separated from the nitric acid phase and then divided into two parts. Part A was water washed to extract the residual acid, dried over sodium sulfate, and concentrated by distilling off the lowboiling cyclohexane. This is the procedure used on essentially all previous samples. Anhydrous barium carbonate was added to Part $B$ to neutralize the residual acid prior to distillation of the organic phase. Results show the nitrocyclohexane yield to be slightly higher in the sample treated with barium carbonate. However, the difference in results from the two procedures is probably not significant and certainly will not influence the conclusions regarding the effect of radiation on the nitration reaction.

The same spectrum of reaction products was obtained in experiments using either nitric acid or nitrogen dioxide as a nitrating agent. The nitrocyclohexane yield was found to increase with an increase in reaction time. In comparing irradiation and the rmal experiments, it appears that thermal reactions produce a slightly higher yield of nitrocyclohexane, but the increase is probably not significant.

From the results of these $\mathrm{NO}_{2}$ experiments and the previous $\mathrm{HNO}_{3}$ experiments, it can be seen that the yields of reaction products are of the same order of magnitude for both experimental systems. Therefore, the type of nitrating agent apparently has no significant effect on the radiation-induced nitration of cyclohexane.

On the basis of the results obtained in this program it is concluded that radiation ha:s little, if any, effect on nitration reactions. Surface conditions, temperature, and hom nogeneity of reactants have much larger influences on the rate of reaction than the presence or absence of radiation. Therefore, no further work is recommended in this area. 
TABLE H-2. PRODUCT ANALYSIS OF NITRIC ACID- OR NITROGEN DIOXIDE-CYCLOHEXANE EXPERIMENTS AT $60 \mathrm{C}$

\begin{tabular}{|c|c|c|c|c|c|c|c|c|c|c|c|}
\hline \multirow[b]{2}{*}{ Experiment (a) } & \multirow{2}{*}{$\begin{array}{c}\mathrm{C}_{6} \mathrm{H}_{12} / \mathrm{HNO}_{3} \\
\text { or } \mathrm{NO}_{2} \\
\text { Mole Ratio }\end{array}$} & \multirow[b]{2}{*}{$\begin{array}{c}\text { Time, } \\
\mathrm{hr}\end{array}$} & \multirow[b]{2}{*}{$\begin{array}{c}\text { Gamma Dose, } \\
106 \text { rads }\end{array}$} & \multirow{2}{*}{$\begin{array}{c}\text { Moles of } \\
\text { Gas } \\
\text { Produced }\end{array}$} & \multicolumn{7}{|c|}{ Analysis of Recovered Organic Solution, w/o } \\
\hline & & & & & $\mathrm{C}_{6} \mathrm{H}_{11} \mathrm{NO}_{2}$ & $\left(\mathrm{C}_{6} \mathrm{H}_{11}\right)_{\mathrm{m}}\left(\mathrm{NO}_{2}\right)_{\mathrm{n}}$ & $\mathrm{C}_{6} \mathrm{H}_{11} \mathrm{ONO}_{2}$ & $\left(\mathrm{C}_{6} \mathrm{H}_{11}\right)_{2}$ & $\mathrm{C}_{6} \mathrm{H}_{11} \mathrm{OH}$ & $\mathrm{C}_{5} \mathrm{H}_{10} \mathrm{C}=\mathrm{O}$ & $\begin{array}{c}\text { Adipic Acid or } \\
\text { Other Solids }\end{array}$ \\
\hline $66 \mathrm{~A}$ & $10.2 / 1$ & 20 & 3.8 & 0.010 & 0.41 & - & -- & -- & Trace & Trace & 0.52 \\
\hline $66 \mathrm{~B}$ & & & & 0.010 & 0.52 & -- & -- & -- & Trace & Trace & 0.52 \\
\hline $67 \mathrm{~A}$ & $10.2 / 1$ & 45 & 8.6 & 0.018 & 0.89 & 0.06 & -- & Trace & 0.05 & 0.02 & 3.71 \\
\hline $67 \mathrm{~B}$ & & & & 0.018 & 1.02 & 0.08 & -- & 0.04 & 0.05 & 0.02 & 3.71 \\
\hline 61 & $10.1 / 1$ & 6 & 1.1 & $\begin{array}{l}\text { Not deter- } \\
\text { mined }\end{array}$ & 0.42 & 0.03 & Trace & 0.04 & 0.02 & 0.02 & 0.80 \\
\hline 63 & $9.6 / 1$ & 9 & 1.7 & Ditto & 0.40 & 0.02 & 0.01 & 0.04 & Trace & 0.02 & 1.07 \\
\hline 64 & 11. $5 / 1$ & 9 & -- & $"$ & 0.45 & Trace & - & 0.05 & 0.06 & 0.03 & 1.49 \\
\hline 62 & $10.0 / 1$ & 15 & 2.8 & $"$ & 0.58 & 0.07 & 0.04 & 0.04 & Trace & 0.01 & 0.58 \\
\hline 60 & $9.8 / 1$ & 20 & 3.8 & $"$ & 0.61 & 0.04 & 0.09 & 0.05 & 0.03 & 0.01 & 0.07 \\
\hline 65 & $9.8 / 1$ & 20 & $-\infty$ & $"$ & 0.66 & -. & -- & Trace & 0.13 & 0.04 & 1.30 \\
\hline
\end{tabular}

(a) In Experiments 66 and 67, $70 \mathrm{w} / \mathrm{o} \mathrm{HNO}_{3}$ was used as the nitrating agent and in Experiments 60 to 65 , $\mathrm{NO}_{2}$ was used. 


\section{VOID-DISTRIBUTION AND HEAT-TRANSFER STUDIES (AEC-EURATOM)}

D. V. Grillot, R. O. Wooton, F. Peter, H. M. Epstein, and J. W. Chastain

This program is being conducted to investigate void distribution in subcooled boiling of light water with particular application to reactor conditions. The distribution is measured by a beta-ray attenuation method. In past months the equipment has been constructed and experimental runs started. Flow instability has been virtually elimi-

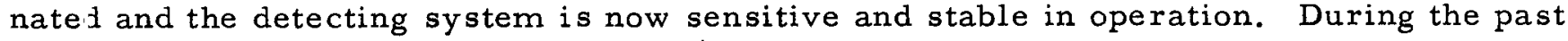
mon:h, improvements have been made in the experimental equipment, and test runs with heat fluxes up to $3 \times 10^{5} \mathrm{Btu} /(\mathrm{hr})\left(\mathrm{ft}^{2}\right)$ have been made.

In the past experimental difficulties resulting from temperature dependence and instibility in the counting system have limited the usefulness of the data. A special ionization chamber which was insensitive to beta particles was constructed and tried in the void-detection system; electronic instabilities made its use impractical. A new $G-M$ tube has improved the stability of the counting system and eliminated all abnormal temperature dependencies.

To improve the sensitivity of the counting system a Lucite sheet 1 in. thick is being used to collimate the cerium-144 source. By collimating the source with Lucite the brerasstrahlung generation has been effectively reduced so that now an 0.8 per cent change in count rate is obtained for each mil of steam generated in the test section.

Additional tests using greater heat fluxes and mass flow rates will be made during the coming month. 


\title{
MATERIALS DEVELOPMENT AND EVALUATION (HAPO)
}

\author{
F. R. Shober
}

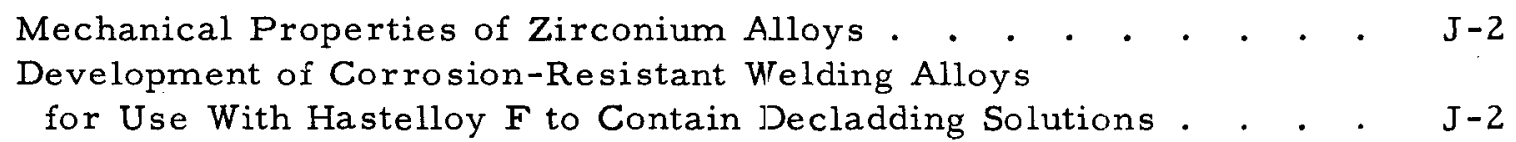

Twenty vacuum creep-test units are being used in the investigation of the creep properties of cold-worked and of annealed Zircaloy-2 at 290, 345, and $400 \mathrm{C}$. Test contitions include long-term constant-load constant-temperature tests, constant-load cycic-temperature tests, and cyclic-load cyclic-temperature tests. In the developmerit of corrosion-resistant welding alloys, a second series of experimental nickel-base alloys has been selected, and alloy preparation has been started. 


\section{Mechanical Properties of Zirconium Alloys}

L. P. Rice and J. A. VanEcho

A long-term program for determining the creep properties of Zircaloy-2 has been under way at Battelle. An outline of the general features of the program as well as a discussion of the general test procedure are included in BMI-1423.

Throughout the month of March, there were 20 creep units containing Zircaloy-2 specimens in operation. Table J-1 contains a summary of current data from these 20 tests.

\section{Development of Corrosion-Resistant Welding Alloys for Use With Hastelloy $F$ to Contain Decladding Solutions}

D. C. Drennen, C. L. Peterson, P. D. Miller,

R. E. Monroe, A. M. Hall, and W. K. Boyd

The compositions in Table $\mathrm{J}-2$ for the second series of experimental nickel-base alloys were selected on the basis of the results obtained for the forming, welding, and corrosion behavior of the initial group of twelve alloys. Fifteen-pound heats of Alloys $20,21,23$, and 24 have been vacuum-induction melted and forged to 3/4-in. -thick slabs. Forging temperatures of 2100 and $2200 \mathrm{~F}$ were determined from studies conducted on pilot ingots of the four alloys. The forging behavior of the four heats was good. However, analytical data have indicated poor recoveries of molybdenum $(57$ to 71 per cent). It is believed that the unexpected good forgeability may be related to the low molybdenum contents. Three of these alloys will be remelted along with the remaining eight of this series. Higher melting temperatures will be used in an attempt to insure complete melting of the molybdenum addition. 
TABLE J -1 . SUMMARY OF CURRENT CREEP TESTS OF ZIRCALOY -2 SHEET IN THE LONGITUDINAL DIRECTION

\begin{tabular}{|c|c|c|c|c|c|}
\hline \multirow[b]{2}{*}{ Spe:imen ${ }^{(a)}$} & \multirow[b]{2}{*}{$\begin{array}{l}\text { Stress, } \\
\text { psi }\end{array}$} & \multirow{2}{*}{$\begin{array}{c}\text { Load on } \\
\text { Deformation, } \\
\text { per cent }\end{array}$} & \multicolumn{2}{|c|}{ Present Status } & \multirow{2}{*}{$\begin{array}{c}\text { Minimum } \\
\text { Creep Rate( } b) \\
\text { per cent per hr }\end{array}$} \\
\hline & & & $\begin{array}{c}\text { Time, } \\
\text { hr }\end{array}$ & $\begin{array}{c}\text { Deformation, } \\
\text { per cent }\end{array}$ & \\
\hline
\end{tabular}

$290 \mathrm{C}(550 \mathrm{~F})$

\begin{tabular}{|c|c|c|c|c|c|}
\hline $\mathrm{Zr} \cdot \mathrm{A}-10$ & 22,500 & 3.18 & 9,200 & 4.32 & 0.00001 \\
\hline $\mathrm{Zr} \cdot \mathrm{A}-13$ & 20,000 & 1.51 & 6,600 & 2.83 & 0.000003 \\
\hline $\mathrm{Zr} \cdot \mathrm{A}-14$ & 17,500 & 1.25 & 6,500 & 1.95 & 0.000002 \\
\hline $\mathrm{Zr} \cdot \mathrm{A}-18$ & 15,000 & 0.64 & 6,250 & 0.96 & $<0.000001$ \\
\hline $\mathrm{Zr} \cdot \mathrm{A}-27$ & 12,500 & 0.22 & 3,100 & 0.40 & $<0.000001$ \\
\hline
\end{tabular}

Temperature Cycled ( $550 \mathrm{~F}$ to Room Temperature Once Weekly)
$\mathrm{Zr} \cdot \mathrm{A}-29$
12,500
0.182
675
0.52
$-(c)$

Temperature and Stress Cycled (550 F to Room Temperature and Stress to 0 Once Weekly)
$\mathrm{Zr} \cdot \mathrm{A}-31$
12,500
0.17
950
0.46

$\underline{345 \mathrm{C}}(650 \mathrm{~F})$

$\begin{array}{llllll}\mathrm{Zr} \cdot \mathrm{A}-15 & 20,000 & 2.24 & 6,300 & 5.75 & 0.000065 \\ \mathrm{Zr} \cdot \mathrm{A}-17 & 17,500 & 1.78 & 6,300 & 2.09 & 0.000032 \\ \mathrm{Zr} \cdot \mathrm{A}-25 & 15,000 & 0.97 & 4,900 & 1.11 & 0.000017 \\ \mathrm{Zr} \cdot \mathrm{A}-28 & 12,500 & 0.32 & 2,100 & 0.42 & 0.000013 \\ 7-\mathrm{r}-1 & 25,000 & 0.23 & 21,200 & 0.81 & 0.000015\end{array}$

Temperature Cycled (650 F to Room Temperature Once Weekly)
$\mathrm{Zr}-\mathrm{A}-30$
10,000
0.054
1,050
0.20

Temperature and Stress Cycled (650 F to Room Temperature and Stress to 0 Once Weekly)
$\mathrm{Zr}-\mathrm{A}-32$
12,500
0.265
800
0.42

$400 \mathrm{C}(750 \mathrm{~F})$

$\begin{array}{lrlrll}\mathrm{Zr}-\mathrm{A}-16 & 12,500 & 0.45 & 6,300 & 3.6 & 0.00035 \\ \mathrm{Zr} \cdot \mathrm{A}-21 & 10,000 & 0.11 & 5,500 & 1.05 & 0.00028 \\ \mathrm{Zr} \cdot \mathrm{A}-26 & 9,000 & 0.08 & 3,500 & 0.36 & 0.000022 \\ 7-4-3 & 15,000 & 0.134 & 18,750 & 1.61 & 0.00006 \\ 7-A-5 & 12,500 & 0.095 & 16,800 & 1.05 & 0.000028 \\ 7-1,-15 & 10,000 & 0.15 & 15,300 & 0.62 & 0.000008\end{array}$

(a) Specimens with designation " $\mathrm{Zr}-\mathrm{A}$ " are annealed, all othe:s are 15 per cent cold-worked material.

(b) Creep rate subject to revision as tests progress.

(c) Test not run long enough to establish creep rate. 
TABLE J-2. COMPOSITIONS OF SECOND SERIES OF EXPERIMENT AL NICKEL-BASE ALLOYS

\begin{tabular}{|c|c|c|c|c|c|c|c|}
\hline \multirow[b]{2}{*}{ Alloy } & \multicolumn{7}{|c|}{ Intended Composition ${ }^{(a)}, w / 0$} \\
\hline & $\mathrm{Ni}$ & $\mathrm{Cr}$ & Mo & $\mathrm{Co}$ & $\mathrm{Fe}$ & $\mathrm{Ti}$ & $\mathrm{Cu}$ \\
\hline 13 & 45 & 22 & 1.5 & -- & 29.5 & 1 & -- \\
\hline 14 & 45 & 22 & 4.5 & -- & 26.5 & 1 & -- \\
\hline 15 & 45 & 22 & 9 & -- & 22 & 1 & -- \\
\hline 16 & 45 & 22 & 9 & $\cdots$ & 21 & 1 & 1 \\
\hline 17 & 50 & 25 & 1.5 & -- & 21.5 & 1 & -- \\
\hline 18 & 50 & 25 & 4.5 & $-\cdot$ & 18.5 & 1 & -- \\
\hline 19 & 50 & 25 & 6 & -- & 17 & 1 & -. \\
\hline 20 & 50 & 25 & 6 & -- & 16 & 1 & 1 \\
\hline 21 & 50 & 25 & 1.5 & -- & 18.5 & 1 & 3 \\
\hline 22 & 25 & 22 & 6 & 25 & 20 & 1 & -- \\
\hline 23 & 25 & 25 & 6 & 25 & 17 & 1 & -. \\
\hline 24 & 25 & 25 & 9 & 25 & 14 & 1 & -- \\
\hline
\end{tabular}

(a) All alloys were intended to contain $0.02 \mathrm{w} / \mathrm{o}$ carbon, $0.6 \mathrm{w} / \mathrm{o}$ manganese, and $0.4 \mathrm{w} / \mathrm{o}$ silicon. 


\title{
DEVELOPMENTS FOR ALUMINUM-CLAD FUEL ELEMENTS (SCL)
}

\author{
R. J. Carlson and N. E. Daniel
}

Preparation of Aluminum-Uranium Alloys . . . . . . . . . K-2

A Study of Aluminum-Uranium-Nickel Eutectic

$$
\text { Temperature . . . . . . . . . . . . . . . . } \mathrm{K}-3
$$

Stress-rupture data for aluminum $-35 \mathrm{w} / \mathrm{o}$ uranium alloys containing 2 and $3 \mathrm{w} / \mathrm{o}$ tin and zirconium have been obtained for $100 \mathrm{hr}$ at $200 \mathrm{C}$. The rupture strength of the binary aluminum-35 w/o uranium alloy under these test conditions excelled that exhibite 1 by the alloys containing the ternary additions. An increase in tin or zirconium content from 2 to $3 \mathrm{w} / 0$ produced a noticeable decrease in rupture strength.

The study concerned with the effects of impurities on the ternary eutectic temperature in the aluminum-uranium-nickel system has been completed. The results indicate that the eutectic alloy prepared from commercial-grade materials exhibited a melting teriperature $3 \mathrm{C}$ lower than the eutectic temperature of the high-purity alloy. 
Preparation of Aluminum-Uranium Alloys

N. E. Daniel, E. L. Foster, and R. F. Dickerson

Aluminum-uranium alloys containing up to $20 \mathrm{w} / \mathrm{o}$ uranium have found wide-spread acceptance as fuels for low-temperature water-cooled water-moderated reactors. For certain applications, aluminum-uranium alloys containing up to $35 \mathrm{w} / \mathrm{o}$ uranium are desired in the form of tubular fuel elements. Previous studies have indicated that casting and fabricating difficulties may be lessened by the use of ternary additions such as tin or zirconium. The improvements in the casting characteristics are attributed to an increase in fluidity in the alloys, whereas the improvements in the fabricating characteristics are attributed to the retention of $\mathrm{UAl}_{3}$ in the cast shapes, thereby increasing the proportion of the ductile aluminum-rich matrix. Before additions of tin and zirconium can be used it is necessary to evaluate their effects upon the physical properties and corrosion resistance of the aluminum-uranium alloys. This program is concerned with the effects of up to $3.0 \mathrm{w} / 0$ tin and zirconium.

Twenty-eight specimens, formed from each of seven aluminum-uranium alloys, have been tested to determine the 100-hr rupture strength of each alloy at $200 \mathrm{C}$. Stress-versus-rupture time and creep-rate curves have been drawn from the data obtained. These indicate some scatter in the data for the binary alloys, but remarkably little scatter in the other data. The stress-rupture data for each alloy were plotted to obtain the values listed in Table $\mathrm{K}-1$ for $100-\mathrm{hr}$ rupture strengths. An extrapolation of the data yielded the values for $1000-\mathrm{hr}$ rupture strengths.

T ABLE K-1. STRESS-RUPTURE STRENGTH OF ALUMINUM-35 w/O URANIUM ALLOYS AT $200 \mathrm{C}$

\begin{tabular}{|c|c|c|c|}
\hline \multirow[b]{2}{*}{ Ingot } & \multirow[b]{2}{*}{. Composition } & \multicolumn{2}{|c|}{ Rupture Strength, psi } \\
\hline & & $\overline{100 \mathrm{Hr}}$ & $1000 \mathrm{Hr}(\mathrm{a})$ \\
\hline 113 & $\mathrm{Al}-35 \mathrm{w} / \mathrm{o} \mathrm{U}$ & 10,100 & 9,200 \\
\hline 105 & $\mathrm{Al}-35 \mathrm{w} / \mathrm{o} \mathrm{U-2} \mathrm{w} / \mathrm{o} \mathrm{Sn}$ & 8,100 & 6,600 \\
\hline 106 & $\mathrm{Al}-35 \mathrm{w} / \mathrm{o} \mathrm{U}-3 \mathrm{w} / \mathrm{o} \mathrm{Sn}$ & 7,000 & 5,200 \\
\hline 117 & $\mathrm{Al}-35 \mathrm{w} / \mathrm{o} \mathrm{U-2} \mathrm{w} / \mathrm{o} \mathrm{Z}_{\mathrm{I}}$ & 8,600 & 7,000 \\
\hline 118 & $\mathrm{Al}-35 \mathrm{w} / \mathrm{o} \mathrm{U}-3 \mathrm{w} / \mathrm{o} \mathrm{Zr}$ & 7,900 & 6,300 \\
\hline $122(b)$ & $\mathrm{Al}-35 \mathrm{w} / \mathrm{o} \mathrm{U-2} \mathrm{w} / \mathrm{o} \mathrm{Zr}$ & 9,000 & 7,500 \\
\hline $123(\mathrm{~b})$ & Al-35 w/o U-3 w/o ZI & 8,700 & 7,100 \\
\hline
\end{tabular}

(a) $1000 \mathrm{hr}$ strengths are extrapolated from 100 -hr results.

(b) Ingots 122 and 123 were vacuum melted; all others were air melted.

From the data in Table K-1 it can be seen that an increase in tin content from 2 to $3 \mathrm{w} / 0$ will decrease the 100-hr and 1000-hr rupture strengths much more than will a similar increase in zirconium content. The extrapolated 1000-hr rupture strength for the binary alloy may be somewhat high due to the aforementioned scatter in the values obtained. So that the se extrapolated values for the 1000-hr rupture strengths may be substantiated, specimens of each composition are now being tested at or below the indicated stresses. The preparation of alloys containing two or more elemental additions has been held in abeyance pending the completion of full-size extrusion billets containing $25 \mathrm{w} / \mathrm{o}$ uranium. 


\section{A Study of Aluminum-Uranium-Nickel Eutectic Temperature}

V. W. Storhok, A. A. Bauer, and R. F. Dickerson

A study to determine the effects of impurities introduced from commercial-grade allcying materials on the ternary eutectic temperature in the aluminum-uranium-nickel system has been completed.

Differential thermal-analysis data indicate a ternary eutectic temperature of $621 \mathrm{C}$ for an aluminum-13 w/o uranium $-5.6 \mathrm{w} / \mathrm{o}$ nickel alloy prepared from commercial-grade malerials. By comparision, a eutectic temperature of $624 \mathrm{C}$ has been determined for a similar alloy prepared from high-purity materials.

The temperature difference between the eutectics for the two materials was substantiated by a comparative differential thermal-analysis technique in which a highpurity ternary eutectic alloy was substituted for the usual graphite neutral specimen. The resultant curve showed that the commercial-grade alloy exhibited a eutectic temperature which was $3 \mathrm{C}$ lower than the eutectic temperature of the high-purity alloy.

The major impurities in the commercial grades of aluminum and nickel employed in the study are iron and silicon. Either or both of these impurities are probably responsible for the decreased ternary eutectic temperature. 


\title{
REFLECTIVE-INSU LATION STUDIES (KAISER)
}

\author{
L. J. Flanigan and H. R. Hazard
}

Reflective-insulation materials suitable for use in the Experimental Gas-Cooled Reactor are being studied at Battelle. Suitability of the insulation will be judged by its fre $\epsilon$ dom from distortion or other damage occurring during thermal cycling and rapid decompression, and by its insulating value. Work previously reported includes completion of the detailed design of the thermal-cycling equipment and the decompression chamber and initiation of construction of the heat-transfer apparatus and the thermalcyciling equipment.

In March, the detailed design of the heat-transfer apparatus was completed and conistruction continued. Construction of the decompression chamber was started. The corrponents for the thermal-cycling equipment are on hand and will be assembled upon recisipt of insulation specimens, which are expected late in April.

In April construction of the decompression chamber and the heat-transfer apparatis should be completed. 


\title{
PROBLEMS ASSOCIATED WITH THE RECOVERY OF SPENT REACTOR FUIEL ELEMENTS (ORNL)
}

C. L. Peterson and R. A. Ewing

\begin{abstract}
Corrosion Studies of the Fluoride-Volatility Process . . . . . M-2 Study of the Effects of Irradiation on Ciadding- and Core-Dissolution Processes . . . . . . . . . . . . . . M-2
\end{abstract}

In corrosion studies concerned with the Fluoride-Volatility process six Hy $\mathrm{Mu} 80$ allcy fluorinators are being examined metallographically. Preliminary results are encouraging.

Cobalt- 60 has been found to account for most of the gamma activity in cladding solitions from dissolution experiments with ORR-irridiated Consolidated Edison fuel pinis. Sulfex dissolutions are under way on a. new lot of unirradiated Consolidated Edison pinis. Dissolution rates have been below those observed previously. 


\section{Corrosion Studies of the Fluoride-Volatility Process}

P. D. Miller, C. L. Peterson, W. K. Boyd, W. N. Stiegelmeyer, and F. W. Fink

A corrosion evaluation using metallographic techniques is being made on six miniature fluorinators which were used in experiments at ORNL. The containers, which were about $1 \mathrm{in}$. in diameter and $8 \mathrm{in.}$ long, were made from Hy Mu 80 , which has a nominal composition of $80 \mathrm{w} / \mathrm{o}$ nickel- $16 \mathrm{w} / \mathrm{o}$ iron $-4 \mathrm{w} / \mathrm{o}$ molybdenum. The gas inlet tube and exit lines were made from "A"-Nickel.

Preliminary results indicate that the Hy Mu 80 alloy is more resistant than " $A$ "Nickel to the fluorination conditions. More detailed results will be available next month.

\section{Study of the Effects of Irradiation on Cladding- and} Core-Dissolution Processes

R. A. Ewing, H. B. Brugger, and D. N. Sunderman

\section{Sulfex Process}

An investigation has been started to identify and measure the individual radioisotopes contributing to the gamma activities of the cladding and core solutions resulting from the dissolutions of ORR-irradiated Consolidated Edison fuel pins. Preliminary chemical separations of several cladding solutions have been made by selective elution from anion-exchange resin columns. Gamma spectrometry of the eluted fractions has shown that the principal radioisotope present (after 10 months of cooling) is cobalt-60, which accounts for nearly 100 per cent of the observed gamma activity of approximately $1 \times 10^{9} \mathrm{cpm}$ per $\mathrm{ml}$. No significant amounts of fission-product activity were found. These data indicate that the cladding had been fabricated from commercial Type 304 stainless steel, which contains approximately $0.1 \mathrm{w} / 0$ cobalt. Had low-cobalt nucleargrade stainless been used the radioactivity of the cladding solutions would be nearly two orders of magnitude lower.

The first Sulfex dissolution has been completed on one of a new lot of "cold" Consolidated Edison prototype pins which more nearly approach design specifications ( $\mathrm{UO}_{2 .} 3$ and $\sim 90$ per cent of theoretical density). Thorium and uranium losses to the cladding solution were $\sim 0.02$ and $\sim 0.3$ per cent, respectively, and were similar to those previously observed except that the losses did not perceptibly increase after a 15-hr refluxing of the dejacketed pellets with the cladding solution in a nitrogen atmosphere.

Dissolution of the core was markedly less complete than on the previously tested core having a lower density and a higher oxygen: uranium ratio. Only 70 per cent of the core dissolved during the first core-dissolution step, rather than the expected 90 to 95 per cent. Due to the large residue of core, the acid: core ratio was considerably below the desired 10:1 volume:weight ratio in the second step, and dissolution of the core was not complete after $16 \mathrm{hr}$. These data indicate that pins of this type will require longer core-dissolution times, as well as increased quantities of core dissolvent. 
Several MTR-irradiated loop-test specimens of Consolidated Edison-type fuel pin:s ( 700 MWD/T of core) have just been released from postirradiation studies for disisolution tests. Preliminary studies are to be conducted during the next month on several duplicate unirradiated specimens which were exposed to the same thermal conditions as the irradiated specimens in an out-of-pile test. Dissolutions of the irradiated specimens can probably begin the following month.

\section{Darex Process}

No Darex dissolutions were conducted during the month. Some Darex tests will be unade on the fuel pins described above. 


\section{VARIABLE-MODERATOR REACTOR CRITICAL-ASSEMBLY STUDIES (ATL-A)}

\section{R. A. Egen, L. H. Bettenhausen, W. S. Hogan,} D. A. Dingee, and J. W. Chastain

A critical-assembly research program is being conducted to aid the Advanced Technology Laboratories of American-Standard Corporation in their development of the Variable-Moderator Reactor. For the past 3 months preparations were made for initiating the experimental studies.

During March installation of control and research instrumentation was completed. A zomplete operational checkout was made without fuel-pin assemblies. Minor diffi- · culties were encountered and corrected.

The remaining regular fuel pins were received and fuel elements were assembled as quickly as pin delivery permitted.

Initial approaches to criticality will begin during the next month. Experimentaticn will continue with determinations of critical configurations, reactivity effects of licuid-height changes, and neutron-flux distributions for various core configurations. 
URANIUM CARBIDE AS A REACTOR FUEL(AI)

E. I. Foster and F. A. Rough

Irradiation of Uranium Monocarbide $\quad \cdot \quad \cdot \quad \cdot \quad \cdot \quad \cdot \quad \cdot \quad \cdot \quad \cdot \quad \cdot \quad 0-2$

Postir radiation Examination of Uranium Monocarbide $\cdot$. $\cdot$. $\cdot$. O-2

Additional burnup values are reported for two capsules of irradiated carbide specimens. These new values, obtained both by isotopic analysis for uranium-236 anc. cesium-137 analysis are higher than earlier values based upon dosimetry. One adcitional capsule of uranium carbide specimens being irradiated to achieve a burnup of $20,000 \mathrm{MWD} / \mathrm{T}$ of uranium will be discharged from the MTR in June. 
$0-2$

Irradiation of Uranium Monocarbide

D. Stahl, J. H. Stang, and W. H. Goldthwaite

The irradiation of Capsule BMI-23-4, containing uranium-5 w/o carbon specimens, is continuing in the A-27-SE position of the MTR. The capsule is scheduled for dis charge from the MTR at the end of Cycle 140 (mid-June, 1960) for a total irradiation of $26 \mathrm{MTR}$ cycles and a target burnup of $20,000 \mathrm{MWD} / \mathrm{T}$ of uranium. Calculated specimen center-line temperatures during March were in the 1050 to $1100 \mathrm{~F}$ range.

\section{Postirradiation Examination of Uranium Monocarbide}

S. Alfant, A. W. Hare, and R. F. Dickerson

The primary object of this investigation is to determine the changes in the properties of uranium monocarbide produced by neutron irradiation.

At this time Capsules BMI-23-1, BMI-23-2, BMI-23-3, and BMI-23-5 have been irradiated at the $M T R$ and all postirradiation examinations have been completed on the specimens from these capsules.

Examination of Capsule BMI-23-6 has been initiated at the Battelle Hot-Cell Facility. The data compiled after postirradiation tests and measurements indicated that the effects of irradiation were negligible on the uranium-4. $8 \mathrm{w} / \mathrm{o}$ carbon specimens after irradiation at the MTR for six cycles to estimated burnups of approximately 0.69 a/o of uranium (5100 MWD/T of uranium) and $0.72 \mathrm{a} / \mathrm{o}$ of uranium $(5400 \mathrm{MWD} / \mathrm{T}$ of uranium) for the top and bottom specimens, respectively.

During the past month analyses by the isotopic-detection method to determine burnup for the specimens from Capsules BMI-23-3 and BMI-23-5 were completed. In addition, radiochemical burnup analyses were completed on these specimens. The burnups based on the results of the isotopic analyses were 13,800 and 8, $100 \mathrm{MWD} / \mathrm{T}$ of uranium*, respectively, for Capsules BMI-23-3 and BMI-23-5. The burnups based on the radiochemical analyses were 15,700 and $8,600 \mathrm{MWD} / \mathrm{T}$ of uranium ${ }^{*}$, respectively, for Capsules BMI-23-3 and BMI-23-5.

Specimens from Capsule BMI-23-6 have been sent to the CPP for burnup determinations by the isotopic detection method and the cesium-137 radiochemical method. The results of these analyses plus the analyses of the dosimeter wires will be available soon.

\footnotetext{
- Based on a metric ton of uranium and $195 \mathrm{Mev}$ per fission.
} 
PEBBLE-BED REACTOF MATERIALS (S \& P)

\author{
W. S. Diethorn
}

\begin{abstract}
Laboratory Evaluation of Fueled-Graphite Spheres . . . . . . . P-2
Fabrication Development of Coated Fuel Particles . . . . . . . P-2

$\mathrm{Al}_{2} \mathrm{O}_{3}$-Coated $\mathrm{UO}_{2}$.

Carbon-Coated Uranium Carbide. . . . . . . . . . . P-2

Carburization Studies. . . . . . . . . . . . . . . P-3

Subsurface Coatings . . . . . . . . . . . . . . . . . $\quad$. P-3

Fission-Product Release from Fueled-Graphite Spheres . . . . . P-4

Neutron-Activation Studies . . . . . . . . . . . . . P-4

In-Pile Capsule Experiments . . . . . . . . . . . . P-5
\end{abstract}

In support of the Pebble-Bed Reactor program Battelle is studying the mechanical properties, radiation damage, and fission-gas release of 1.5-in. -OD fueled-graphite sphe::es. Coated and uncoated spheres for these evaluation studies are prepared by comriercial vendors. The materials development at Battelle consists of the work on coated particles and the work, reported for the first time this month, on subsurface coatings. 


\title{
LABORATORY EVALUATION OF FUELED-GRAPHITE SPHERES
}

M. C. Brockway and A. K. Smalley

In this phase of the program, impact and compression resistance, metallography, self-welding, and the coating porosity of fueled-graphite spheres are being investigated. Hot-oil tests provide information on gross coating porosity. A large number of spheres have been examined in the program. Several candidates are now available for the increased emphasis on the study of radiation damage and fission-gas release.

\section{FABRICATION DEVELOPMENT OF COATED FUEL PARTICLES}

\author{
A. K. Smalley
}

$$
\mathrm{Al}_{2} \mathrm{O}_{3} \text {-Coated } \mathrm{UO}_{2}
$$

M. Browning and J. M. Blocher

A fluidized-bed technique is being used to prepare $\mathrm{Al}_{2} \mathrm{O}_{3}$-clad $\mathrm{UO}_{2}$ for irradiation evaluation.

The effect of thermal cycling on two batches of natural particles has been studied this month. Coatings on both batches were about $50 \mu$ thick and were applied at 1830 and $2010 \mathrm{~F}$, respectively. Cycling was done in a reducing atmosphere (nitrogen-10 volume per cent hydrogen). Samples were heated to $2500 \mathrm{~F}$ in about $2 \mathrm{~min}$, allowed to soak for $15 \mathrm{~min}$, and then quenched to $600 \mathrm{~F}$ in about $2 \mathrm{~min}$. After nine of the se heat-quench $\mathrm{cy}-$ cles, the samples were examined microscopically. No cracked coatings were seen in either batch $(30 \mathrm{X})$. Following these cycling experiments the two batches were heated in $1200 \mathrm{~F}$ air for $5 \mathrm{hr}$. One batch did not change weight. The second batch decreased in weight by 0.02 per cent. The cycling and air-oxidation tests on the se two batches show that thermal cycling in a nonoxidizing atmosphere does not damage the cladding. Alpha assays of the coated particles before and after thermal cycling support this conclusion.

Depleted 250 to $420-\mu \mathrm{UO}_{2}$ shot has been received from $\mathrm{MCW}$. Equipment is being as sembled for the preparation of $40-\mu$ coatings.

\section{Carbon-Coated Uranium Carbide}

A. C. Secrest, J. H. Oxley, and J. M. Blocher

Particles of $\mathrm{UC}$ and $\mathrm{UC}_{2}$ are being coated with carbon by a fluidized-bed technique in a new program initiated this month.

Two $100-\mathrm{g}$ lots of 250 to $275-\mu \mathrm{UC}_{2}$ particles have been coated with carbon by the thermal decomposition of methane and acetylene at 1830 and $2010 \mathrm{~F}$ in a fluidized bed of the particles. Coating thicknesses are 20 and $40 \mu$. Samples of the se two batches have 
been leached in nitric acid, but the results of this test are not available yet. Thermalcycling tests and alpha assays are plánned.

\section{Carburization Studies}

A. F. Gerds

The reaction between vapor-deposited $\mathrm{Al}_{2} \mathrm{O}_{3}-\mathrm{UO}_{2}$ particles and graphite is being studied by heating compacted and baked dispersions at $2500 \mathrm{~F}$ for times up to $1000 \mathrm{hr}$. Two grades of graphite and $\mathrm{UO}_{2}$ particles coated with 20 - and $50-\mu \mathrm{Al}_{2} \mathrm{O}_{3}$ are being investigated.

Specimens examined after heating for 1 week $(168 \mathrm{hr}$ ) at $2500 \mathrm{~F}$ showed very little, if an reaction. A 500-hr test has been completed, but results are not available. It is experted that a $1000-h r$ test will be completed in April.

\section{SUBSURFACE COATINGS}

A. J. Roese, W. C. Riley, and W. H. Duckworth

One method of retaining fission products in a spherical graphite fuel element is to place: a coating or seal between the fueled graphite and an unfueled graphite shell. A study is under way to explore some of the fabrication problems. The metal or ceramic seal must be free of cracks and pores, and imprevious to fission products up to the maximur. fuel-element operating temperature. Although neutron cross section is important in the selection of the seal material, this factor is not the overriding one in this exploratory study. At present, there are no plans to prepare candidate spheres for irradiation evaluation.

Two methods of forming the desired seal are being studied. One of these involves melting the seal in-pile and relying on fission-gas pressure and capillary action to promote penetration of the seal material into the pores of the unfueled graphite shell. The seal material will freeze at the lower temperatures found in the shell, thus blocking the pores.

Selection of the seal materials is based on the following criteria:

(1) The melting point must exceed $1700 \mathrm{~F}$, the minimum bake temperature for removing volatiles in the graphite binder.

(2) The melting point should not exceed $2400 \mathrm{~F}$. If the seal has a higher melting point, only a small percentage of the fuel elements in the PBR will attain sufficient temperature to cause melting.

(3) The seal material must wet and penetrate graphite.

Wetting and penetration properties of a few seal materials have been studied by heating materials in graphite crucibles at 1800,2200 , or $2600 \mathrm{~F}$. Metallographic results 
indicate that copper, nickel, silicon, and two barium-containing glasses may be suitable seal materials. More detailed experiments involving graphite-seal sandwiches are under way, and results will be reported next month.

The preparation of prototype fuel elements by cold pressing metal powder on prebaked, fueled innerspheres and cold pressing an outer shell around the seal have been completed. Results indicate that large voids develop as the seal material penetrates the graphite. In an attempt to eliminate these voids, hot pressing has been used. Preliminary results on specimens with nickel seals are encouraging.

The second method of preparation involves heat treating the sphere to cause migration of the seal material into available pores in the unfueled graphite shell. In this method, the melting point of the seal should be greater than the maximum reactor temperatures. Preliminary experiments were designed to take advantage of the known diffusion of chromium, MoSi 2 , titanium, and their carbides in graphite. Results on specimens prepared by cold pressing and heat treatment show excellent penetration of all three materials in graphite. Metal or carbide flecks are observed on the surface of the unfueled graphite shell and radiographs show that large amounts of metal or carbide penetrate into the shell. However, the problem of a residual void between the core and the shell remains. Hot pressing of these bodies will be attempted.

\section{FISSION-PRODUCT RELEASE FROM FUELED-GRAPHITE SPHERES}

W. S. Diethorn

In this phase of the program coated, fueled-graphite spheres and clad $\mathrm{UO}_{2}$ are neutron activated, and the fission-gas release is studied during postirradiation heating. Good spheres are advanced to the in-pile irradiation study.

\section{Neutron-Activation Studies}

H. S. Rosenberg

In the preparation for the sweep-capsule experiment, SP-5, several spheres were neutron activated and heated to determine the xenon-133 release (Table P-1). A description of the SP-5 specimens is given in the subsequent section on capsule experiments (Table P-4). Fission-gas retention is excellent in all three specimens.

TABLE P-1. NEUTRON-ACTIVATION RESULTS

\begin{tabular}{|c|c|c|c|}
\hline Specimen & $\begin{array}{c}\text { Postirradiation } \\
\text { Heat-Treatment } \\
\text { Temperature, F }\end{array}$ & $\begin{array}{c}\text { Time at } \\
\text { Temperature, } \\
\text { min }\end{array}$ & $\begin{array}{l}\text { Fission-Gas Release, } \\
\text { per cent of xenon-133 }\end{array}$ \\
\hline $\mathrm{FA}-23$, No. E8-7 & 2000 & 240 & $<2.2 \times 10^{-5(a)}$ \\
\hline FA-20, No. 338 & 1900 & 180 & $<9.3 \times 10^{-5(a)}$ \\
\hline FA-22, No. 471 & 1950 & 240 & $7.7 \times 10^{-4}$ \\
\hline
\end{tabular}

(a) No detectable release. 


\section{In-Pile Capsule Experiments}

D. Stahl, G. E. Raines, R. J. Burian, and W. H. Goldthwaite

$\underline{\mathrm{SP}-4}$

Static Capsule SP-4 was removed from the BRR and examined in the hot cell after an ascumulated irradiation time of 150 days. The burnup of the six fully enriched specimer.s (Table $P-2$ ) is estimated to be 6 to 7 per cent of the uranium-235. This estimate will be checked in April. No radiochemical burnup determinations are planned.

TABLE P-2. SP-4 SPECIMENS

\begin{tabular}{|c|c|c|c|c|c|c|}
\hline \multirow[b]{3}{*}{ Spe simen } & \multirow[b]{3}{*}{ Supplier } & \multirow{2}{*}{\multicolumn{2}{|c|}{ Fuel Form }} & \multirow{3}{*}{$\begin{array}{c}\text { Fuel Particle } \\
\text { Size, } \mu\end{array}$} & \multicolumn{2}{|c|}{ Coating } \\
\hline & & & & & \multirow[b]{2}{*}{ Type } & \multirow{2}{*}{$\begin{array}{c}\text { Thickness, } \\
\text { mils }\end{array}$} \\
\hline & & Initial & Final & & & \\
\hline FA-1, No. 82 & National Carbon & $\mathrm{UO}_{2}$ & $\mathrm{UO}_{2}$ & 100 to 150 & None & - \\
\hline FA-8, E6 & Carborundum & $\mathrm{UC}_{2}$ & $\mathrm{UC}_{2}$ & 100 to 200 & $\mathrm{SiC}-\mathrm{Si}$ & 30 \\
\hline $\mathrm{FI}-1,1: 8$ & Sylcore & UNH & $\mathrm{UO}_{2}$ & 1 & None & -- \\
\hline FA-2, No. 8 & BMI & $\mathrm{UO}_{2}$ & $\mathrm{UO}_{2}$ & 67 & None & -- \\
\hline FA-20. No. 336 & National Carbon & $\mathrm{UO}_{2}$ & $\mathrm{UC}_{2}$ & 100 to 150 & $\begin{array}{c}\text { Pyrolytic } \\
\text { carbon }\end{array}$ & 2 \\
\hline $\mathrm{FA}-10 \quad \mathrm{E} 5$ & Great Lakes Carbon & $\mathrm{UO}_{2}$ & $\mathrm{UO}_{2}$ & 350 to 420 & None & -- \\
\hline
\end{tabular}

All six specimens were intact after rernoval from the capsule. The four uncoated specimens showed no change in surface appearance under low magnification. Five, closıly spaced, parallel, great-circle cracks were observed in the coating of the FA-20 specimen. As expected, the se hairline craclss leaked profusely in the hot-oil test. The re is some evidence that leakage also occurred in a few areas far removed from the crack region. The FA-8 specimen leaked profusely along a 0.2 -in. crack in the coating. No kubbles were observed outside the crack area. The leak is best described as a dense sheet of bubbles. This hairline crack has a jagged appearance at $12 \mathrm{X}$.

Weight and dimensional changes are reported for the se nominal 50-g, 1.5-in.-OD specimens in Table P-3.

TABLE P-3. WEIGHT AND DIMENSIONAL CHANGES IN SP-4 SPECIMENS

\begin{tabular}{lcl}
\hline \multicolumn{1}{c}{ Specimen } & Weight Change, mg & \multicolumn{1}{c}{ Diameter Change, mils } \\
\hline FA-1, No. 82 & -54 & $-7.7,-7.0$ \\
FA-8, E6 & +78 & $-2.5,+5.4,+9.8$ \\
FI-1, E8 & -212 & $-9.9,-11.2$ \\
FA-2, No. 8 & -248 & $-1.2,-0.5$ \\
FA-20, No. 336 & +99 & $-2.9,-6.3,-4.7,-4.0,+3.1$ (a) \\
FA-10, E5 & -33 & $-11.9,-10.2$ \\
\hline
\end{tabular}

(a) Very poor reproducibility at this point on specimen. A value as high as -14 mils was observed on a second measurement. 
Metallography of fuel particles embedded in the sphere surfaces, and internal metallography of the FA-1, FA-20, and FA-8 specimens are planned. Impact-test results on the uncoated specimens will be reported next month.

$\underline{S P-5}$

The new target date for BRR insertion of Sweep Capsule SP-5 in the BRR is April 4. Four static specimens and two sweep specimens will be irradiated for 10 BRR cycles at sphere-surface temperatures of $1500 \mathrm{~F}$. Estimated burnup is to be 3 to 6 per cent, depending on specimen location in the capsule, of the fully enriched uranium. As described last month (BMI-1423), exit sweep helium from each of the two sweep compartments will pass through a delay trap located near the capsule. Radiochemical analysis of the trap contents will provide information on the release of short-lived fission gases which decay to long-lived daughters in the trap. The SP-5 specimens are described in Table P-4.

TABLE P -4 . SP -5 SPECIMENS

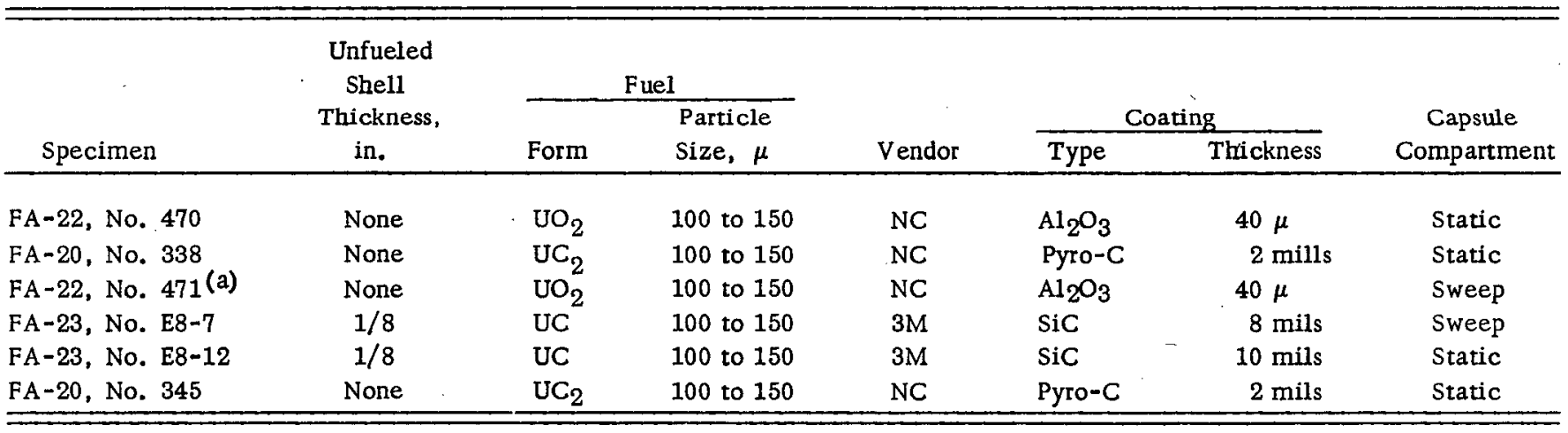

(a) BMI-prepared $\mathrm{Al}_{2} \mathrm{O}_{3}$-clad $\mathrm{UO}_{2}$.

Capsule assembly is nearing completion. The two coated specimens passed the hot-oil test and showed good xenon-133 retention before assembly of the capsule sweep compartments.

$\underline{\text { SPF }-1}$

The SPF-1 low-flux furnace capsule, containing a natural, coated, fueled-graphite sphere, was opened and examined in the hot-cell during March. The specimen, FA-20, No. 310, was intact and free of cracks, but leaked badly in the hot-oil test. There was no evidence of coating failure in the neutron-activation study prior to capsule irradiation. In the hot cell, fine streams of bubbles were observed over the entire surface of the sphere during the hot-oil test. While a crack-free coating was verified under examination at low magnification, pits were observed in the coating. Most of the se surface pits are concentrated in an area equal to about one-fifth of the total sphere surface. The origin of the se pits is unknown. The profuse leakage observed with this specimen in the hot-oil test is not in agreement with the in-pile fission-gas release data.

Additional hot-oil tests and neutron-activation studies with this specimen outside the hot cell are planned. In addition, coating-matrix metallography is under consideration. 
$\underline{S P F \cdot .2}$

The SPF-2 furnace-capsule experiment was completed in March. This capsule contilins a 3 M FA-16 graphite sphere fueled with 150- $\mu$ natural UC, and coated with 3 mils of SiC-silicon. All R/B data are reported in Table P-5. The se final data show that the coating on this very-low-burnup specimen is a very good fission-gas barrier.

No postirradiation examination is planned.

TABLE P-5. SUMMARY OF SPF-2 FISSION-GAS DATA

\begin{tabular}{|c|c|c|c|c|c|c|c|c|}
\hline \multirow[b]{2}{*}{ Sampli: } & \multirow{2}{*}{$\begin{array}{l}\text { Collection } \\
\text { Date }(1960)\end{array}$} & \multirow{2}{*}{$\begin{array}{l}\text { Temperature, } \\
\text { F }\end{array}$} & \multirow{2}{*}{$\begin{array}{l}\text { Flux, } \\
\mathrm{n} /\left(\mathrm{cm}^{2}\right)(\mathrm{sec})\end{array}$} & \multicolumn{5}{|c|}{$R / B^{(b)}$} \\
\hline & & & & Xenon-133 & Xenon-135 & Krypton-85m & Krypton -87 & Krypton-88 \\
\hline 1 & $2-10^{(a)}$ & 200 & $1.7 \times 10^{10}$ & $\cdots$ & -- & $\cdots$ & -- & $\cdots$ \\
\hline 2 & $2-11$ (a) & 1000 & $1.7 \times 10^{10}$ & $\cdots$ & $\because$ & - & $-\infty$ & $-\infty$ \\
\hline 3 & $2-12^{(a)}$ & 1000 & $3 \times 10^{11}$ & -- & - & $-\infty$ & -. & -- \\
\hline 4 & $2-15(a)$ & 1000 & $3 \times 10^{11}$ & $-\infty$ & - & $\cdots$ & -- & $-\infty$ \\
\hline 5 & $2-17^{(a)}$ & 1000 & $3 \times 10^{11}$ & - & -- & - & -- & -- \\
\hline 6 & $2-19$ & 1500 & $3 \times 10^{12}$ & $6.1 \times 10^{-6}$ & $6.1 \times 10^{-7}$ & $5.1 \times 10^{-7}$ & $<1.3 \times 10^{-7}$ & $3 \times 10^{-7}$ \\
\hline 7 & $2-22$ & 1500 & $3 \times 10^{12}$ & $2.8 \times 10^{-6}$ & $2.0 \times 10^{-7}$ & $8.1 \times 10^{-7}$ & $<1.3 \times 10^{-7}$ & $2.7 \times 10^{-7}$ \\
\hline 8 & $2-26$ & 1500 & $3 \times 10^{12}$ & $2.1 \times 10^{-6}$ & $1.6 \times 10^{-7}$ & $3.1 \times 10^{-7}$ & $<1.3 \times 10^{-7}$ & $1.7 \times 10^{-7}$ \\
\hline 9 & $2-20$ & 1500 & $3 \times 10^{12}$ & $1.7 \times 10^{-6}$ & $1.1 \times 10^{-7}$ & $3.1 \times 10^{-7}$ & $<1.3 \times 10^{-7}$ & $1.7 \times 10^{-7}$ \\
\hline 10 & $3-2$ & 1900 & $3 \times 10^{12}$ & $2.6 \times 10^{-6}$ & $3.8 \times 10^{-7}$ & $6.7 \times 10^{-7}$ & $<1.3 \times 10^{-7}$ & $1.5 \times 10^{-7}$ \\
\hline 11 & $3-3$ & 1900 & $3 \times 10^{12}$ & $4.5 \times 10^{-6}$ & $4.2 \times 10^{-7}$ & $4.1 \times 10^{-7}$ & $<1.3 \times 10^{-7}$ & $1.2 \times 10^{-7}$ \\
\hline 12 & $3-14$ & 1900 & $3 \times 10^{12}$ & $8.2 \times 10^{-6}$ & $2.0 \times 10^{-7}$ & $7.0 \times 10^{-7}$ & $<1.3 \times 10^{-7}$ & $3.0 \times 10^{-7}$ \\
\hline 13 & $3-15$ & 1900 & $3 \times 10^{12}$ & $4.3 \times 10^{-6}$ & $2.5 \times 10^{-7}$ & $4.7 \times 10^{-7}$ & $<1.3 \times 10^{-7}$ & $1.0 \times 10^{-7}$ \\
\hline
\end{tabular}

(a) Very low releases prevented species identification, so no $R / B$ values are reported.

(b) $\mathrm{R}:$ : the number of atoms released per second from the sphere.

$B:$ : the number of atoms generated per second in the sphere.

\section{SPF - 3}

Furance Capsule SPF-3, containing National Carbon Sphere 449, was inserted in the J3RR during March. This uncoated sphere contains natural $\mathrm{Al}_{2} \mathrm{O}_{3}$-coated $\mathrm{UO}_{2}$ dispersed in graphite. Coating thickness is 40 to $60 \mu \mathrm{R} / \mathrm{B}$ data are reported in Table P-6. The first gas sample collected $(150 \mathrm{~F})$ showed no activity above background. The fission-gas retention was very good and comparable to that for the coated sphere in SPF -2 .

- This capsule experiment has been operated with the gas train presently committed to $S]^{3}-5$, and has been terminated. Continuation of the experiment is planned when a new gas rain, now under construction, becomes operational.

TABLE P-6. SUMMARY OF SPF-3 FISSION-GAS DATA

\begin{tabular}{|c|c|c|c|c|c|c|c|c|}
\hline \multirow[b]{2}{*}{ Sampl } & \multirow{2}{*}{$\begin{array}{c}\text { Collection } \\
\text { Date }(1960)\end{array}$} & \multirow{2}{*}{$\begin{array}{c}\text { Temperature, } \\
\text { F }\end{array}$} & \multirow{2}{*}{$\begin{array}{l}\text { Flux, } \\
\mathrm{n} /\left(\mathrm{cm}^{2}\right)(\mathrm{sec})\end{array}$} & \multicolumn{5}{|c|}{$\mathrm{R} / \mathrm{B}$} \\
\hline & & & & Xenon-133 & Xenon-135 & Krypton-85m & Krypton -87 & Krypton -88 \\
\hline 2 & $3-17$ & 1000 & $1.8 \times 10^{12}$ & $1.2 \times 10^{-6}$ & $1.7 \times 10^{-7}$ & $5.6 \times 10^{-7}$ & $4.2 \times 10^{-7}$ & $2.6 \times 10^{-7}$ \\
\hline 3 & $3-18$ & 1500 & $1.8 \times 10^{12}$ & $5.8 \times 10^{-6}$ & $1.7 \times 10^{-6}$ & $2.0 \times 10^{-6}$ & $1.0 \times 10^{-6}$ & $3.2 \times 10^{-7}$ \\
\hline
\end{tabular}




\title{
TANTALUM AND TANTALUM ALLOYS FOR
} LAMPRE APPLICATIONS (LASL)

\author{
J. H. Stang
}

\begin{abstract}
Development of Container Materials for: LAMPRE Applications. . . Q-2 Effect of Irradiation Damage of Tantalum . . . . . . . . . . Q-2 Precipitate Phase Identification and Interstitial-Type Solid Solubility in Tantalum . . . . . . . . . . . . . Q-3
\end{abstract}

Reports in this section cover investigations being conducted under the auspices of Los Alamos Scientific Laboratory for the LAMPRE development program. In the materials development research, the final (of foul: series over a period covering approximately 15 months) series of binary tantalum-base alloys is being processed from arccast buttons to strip material suitable for plutonium-alloy corrosion exposures at Los Alanıos. It is expected that, by approximately May 1 , the various fabrication operations on the current materials will be completed.

A fairly complete summary is presented of information obtained from postirradiation analyses of irradiated tantalum tensile specimens. A leading finding is that the irradicted material exhibits a considerably greater increase in strength than might be expected considering only the tungsten additive created by the transmutation of tantalum. There are two qualitative explanations for the observed behavior. The first is fastneut: on damage. Although the specimens received a relatively low fast-flux dosage it is possible, since they were irradiated at a low temperature (estimated to be no greater than $300 \mathrm{~F}$ ), that damage from this source is significant in the over-all picture. The second explanation lies in the pickup by the specimens of interstitial contaminants, particularly oxygen, during irradiation. While this is an unlikely possibility in view of the low-temperature conditions which would inhibit any tantalum-oxygen reaction, it cannot be cliecked out since the specimen activity is too high to permit routine chemical analyses to be made.

Lattice-parameter data have been obtained on tantalum-oxygen alloys containing up tc 1.6 a/o oxygen. The se data, obtained on samples homogenized at $1500 \mathrm{C}$ and quen shed, show no evidence that the solid solubility limit has been reached. Higher oxygen samples are being prepared for investigation; also, investigation of the tantalumcarbon and tantalum-nitrogen system is being initiated. 


\section{Development of Container Materials for LAMPRE Applications}

D. C. Drennen, C. J. Slunder, and J. G. Dunleavy

Specimens of binary tantalum-base alloys (of the first group of the fourth series) containing minor additions of hafnium, iron, thorium, and zirconium have been cold cross rolled ( 33 to 41 per cent reduction after pressing and machining) to 0.150 -in. -thick strip with about equal reductions in both directions. These specimens will be given an intermediate anneal at $2600 \mathrm{~F}$ and subsequently cold cross rolled to 0.030 -in. - thick strip.

A second group of alloys of this series will be arc melted in April. The intended compositions of these alloys áre listed in Table Q- 1 .

TABLE Q-1. COMFOSITIONS OF GROUP 2 BINARY TANTALUMBASE ALLOYS OF FOURTH SERIES

\begin{tabular}{rl}
\hline Alloy & $\begin{array}{c}\text { Nominal Composition } \\
\text { (Balance Tantalum), w/o }\end{array}$ \\
\hline 71 & 0.5 aluminum \\
72 & 1.0 aluminum \\
73 & 0.5 boron \\
74 & 1.0 boron \\
76 & 1.0 beryllium \\
78 & 1.0 cerium \\
80 & 1.0 lanthanum \\
82 & 1.0 scandium \\
84 & 1.0 uranium \\
85 & 3.0 yttrium \\
86 & 1.0 titanium \\
101 & 3.0 titanium \\
104 & 100 tantalum (control) \\
105 & 100 tantalum (control) \\
\hline
\end{tabular}

Effect of Irradiation Damage of Tantalum

C. K. Franklin, F. R. Shober, and R. F. Dickerson

This study has the objective of evaluating the effect of neutron irradiation on the mechanical properties of tantalum. Irradiation is expected to produce two effects in tantalum, fast-neutron damage and conversion of tantalum to tungsten. Tantalum tensile specimens were encapsulated and irradiated at the MTR for periods of 69 and 109 days; these periods were chosen to yield a tantalum-1.5 w/o tungsten alloy and a tantalum$3.0 \mathrm{w} / \mathrm{o}$ tungsten alloy. A comparison of the mechanical properties of irradiated tantalum and unirradiated tantalum and arc-melted tantalum-tungsten alloys was made to determine the effect of irradiation on the ductility of tantalum. 
Various tests were performed at room temperature to determine the changes induce 1 by irradiation. Included were tensile tests, microhardness determinations, and simple bend tests. Comparison of the tensile properties before and after irradiation showed increases in strength and losses in ductility as a result of irradiation. Unirradiated tantalum annealed at $1400 \mathrm{C}$ for $1 \mathrm{hr}$ showed a yield strength of about $30,000 \mathrm{psi}$. Afte 1: 69 days of irradiation the material increased in strength to about 70,000 psi. A longer irradiation time of 109 days further increased the strength of the material to abou: 84,000 psi. A decrease of about 83 per: cent in tensile ductility was also observed in the irradiated material, presumably owing to the presence of tungsten atoms (alloying) or to fast-neutron damage or the combination of both. Although this marked decrease in tensile ductility occurred, the irradiated specimens did not exhibit brittle behavior in the bend tests.

Irradiation also brought about a change in the hardness of the material. Using a Tukon hardness tester it was observed that after the 1.09 days of irradiation the material increased in hardness from $120 \mathrm{KHN}$ to $309 \mathrm{KHN}$.

Samples of the irradiated material were analyzed colormetrically for tungsten con. tent. The results indicate that the conversion of tantalum to tungsten was not as great as expected. Only $0.7 \mathrm{w} / 0$ tungsten was formed in the tantalum during the 66-day irradiation period and only about $1.2 \mathrm{w} / 0$ tungsten during the 109 -day irradiation. On the

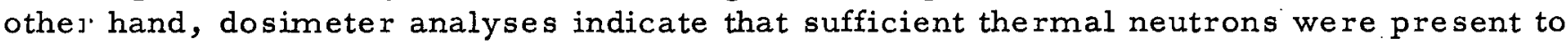
produce the desired alloying effect. The discrepancy between the chemical analyses for tungsten and the amount of tungsten predicted by the dosimeter analyses is not fully understood.

The data in Table Q-2 were obtained during March by radiochemical analyses of the nickel-cobalt dosimeter wires from Capsiles BMI-25-1 and BMI-25-2. The flux values are based on a detection threshold of $3.2 \mathrm{Mev}$.

TABLE Q-2. FAST-FLUX DATA FOR IFRADIATED TANTALUM SPECIMENS

\begin{tabular}{lccc}
\hline Capsule & $\begin{array}{c}\text { Decay } \\
\text { Time, days }\end{array}$ & $\begin{array}{c}\text { Irradiation } \\
\text { Time, days }\end{array}$ & $\begin{array}{c}\text { Average Fast Flux During } \\
\text { Exposure (a), } \mathrm{d} /(\mathrm{cm})(\mathrm{sec})\end{array}$ \\
\hline BMI-25-1 & 172 & 69.5 & $3.38 \times 10^{13}$ \\
BMI-25-2 & 106 & 109 & $1.61 \times 10^{13}$ \\
\hline
\end{tabular}

(a) The thermal fluxes are higher by a factor of approximately 10 .

The experimental work to be performed on the irradiated materials is now completed. Details of the various facets of the over-all program are being incorporated into a topical report.

$\frac{\text { Precipitate Phase Identification and Interstitial-Type }}{\text { Solid Solubility in Tantalum }}$

J. B. Schroeder, D. A. Vaughan, and C. M. Schwartz

The interstitials, carbon, nitrogen, and oxygen, are being added to tantalum by mears of gas-solid reactions, and the resulting alloys are being analyzed by X-ray 
diffraction and metallographic methods to determine the solid solubility limits and the compositions of the initial precipitate phases in these three binary systems. Samples with oxygen additions of up to 2 a/o have been prepared and homogenized at $1500 \mathrm{C}$. Previous $\mathrm{X}$-ray diffraction lattice-parameter determinations on etched specimens were considerably higher than those reported by Wasilewski*or indicated by previous Battelle data.

During the past month, chemical assays of the se specimens for carbon and nitrogen revealed no change in amounts of these elements during the oxygen addition. The oxygen analyses, by vacuum-fusion methods, are given in Table Q-3. Since tantalum might be expected to pick up hydrogen during etching, X-ray lattice-parameter data we re obtained from unetched specimens of the oxygen alloys. These results are also included in Table Q-3. The lattice parameters from the unetched specimens were significantly lower than those of the etched specimen. However, the spread between the BMI data and the interpolated values from Wasilewski's data increases with oxygen content. The lower values obtained by $W$ asilewski may be due to molybdenum pickup from the boat used in his preparation of the oxygen additions. The BMI results on tantalum-oxygen are in agreement with the data of Gebhardt** for the tantalum-nitrogen system where molybdenum contamination was apparently not introduced. This agreement is significant since nitrogen and oxygen would be expected to cause nearly the same lattice expansion when introduced as an interstitial in tantalum. Higher oxygen additions are being prepared by a modified procedure wherein scaling as occurred in Specimen 6A (Table Q-3) should be avoided.

TABLE Q-3. RESULTS OF X-RAY LATTICE -PARAMETER DETERMINATIONS ON UNETCHED SPECIMENS OF T ANT ALUM-OXYGEN ALLOYS

\begin{tabular}{|c|c|c|c|c|}
\hline \multirow[b]{2}{*}{ Specimen } & \multicolumn{2}{|c|}{ Oxygen Analysis } & \multicolumn{2}{|c|}{ Lattice Parameter, A } \\
\hline & $w / 0$ & $\overline{a / o}$ & BMI & Wasilewski \\
\hline Wasilewski & Nil & Nill & -- & 3.3026 \\
\hline $2 \mathrm{~A}$ & 0.0099 & 0.11 & 3. 3033 & $3.3028(a)$ \\
\hline $3 A$ & 0.0435 & 0.49 & 3.3047 & $3.3033^{(a)}$ \\
\hline $4 A$ & 0.0855 & 0.96 & 3.3068 & $3.3039^{(a)}$ \\
\hline $6 \mathrm{~A}$ & 0.1490 (b) & 1.66 & -- & 3.3049 (a) \\
\hline
\end{tabular}

(a) Interpolated from Wasilewski's lattice parameters.

(b) A 4 a/o addition was intended for this specimen; however, it scaled in preparation, resulting in the lower assay.

The initial additions of nitrogen and carbon to tantalum were made during March and are being analyzed. The first X-ray analysis of tantalum-0.5 a/o nitrogen specimen indicated lack of homogeneity after heating for $3 \mathrm{hr}$ at $1500 \mathrm{C}$. Homogenizing treatments at higher temperatures will be employed during the next period.

"Wasilewski, R. J., "The Solubility of Oxygen in, and the Oxide of, Tantalum", J. Am. Chem. Soc., 75, 1001-2 (February 20, 1953).

* Gebhardt, E. , Z. Metallk. , 49 (11), 577-83 (1958). 
DEVELOPMENT OF MATERIALS FOR THE MGCR AND HTGR (GA)

\author{
W. C. Riley
}

High-Burnup Irradiation Effects in Fue:1 Materials . . . . . . . . S-2

Carbon-Transport Corrosion Studies . . . . . . . . . S -3

Thermal Conductivity of Beryllia. . . . . . . . . . . . S-3

Preparation and Coating of Uranium and Thorium Carbide Powders . S-3

Research on core materials for both the MGCR and HTGR is in progress. For the MGCR, the major effort is on development and evaluation of $\mathrm{UO}_{2}$ dispersions in $\mathrm{BeC}$ and $\mathrm{Al}_{2} \mathrm{O}_{3}$ and dispersions of $\mathrm{UC}$ or $\mathrm{UC}_{2}$ in graphite. Currently, the evaluation conisists mainly of static-capsule irradiation in the MTR. In addition, an apparatus for measurement of thermal conductivity of fueled and unfueled beryllia is being prejuared.

For the HTGR, vapor deposition is bejng investigated as a method of preparing and coating uranium and thorium carbide powder. 
High-Burnup Irradiation Effects in Fuel Materials

W. E. Murr, N. E. Miller, J. E. Gates, and R. F. Dickerson

Ceramic-type fuels composed of about 20 volume per cent uranium dioxide in beryllium oxide, 20 volume per cent uranium dioxide in aluminum oxide, 20 volume per cent uranium monocarbide in graphite, and 20 volume per cent uranium dicarbide in graphite are being investigated as potential fuels for the MGCR. A program is in progress to determine the stability of these fuels when irradiated to various degrees of burnup at specimen-surface temperatures near $1500 \mathrm{~F}$.

The evaluation of beryllium oxide-matrix and graphite-matrix fuels consists of the irradiation and postirradiation examination and evaluation of 24 specimens contained in 4 instrumented capsules. Each capsule is equipped with three electrical heaters $(1 \mathrm{kw}$ each) and six thermocouples with a thermocouple adjacent to each specimen. Six specimens, two of each fuel composition, are in each capsule. The specimens are composed of four pellets, each approximately $0.222 \mathrm{in.} \mathrm{in} \mathrm{diameter} \mathrm{by} 0.250 \mathrm{in}$. long, encased in Type 316 stainless steel tubing.

In the initial capsule of this series, which was irradiated in the Battelle Research Reactor, specimen burnups ranged from about 1.1 to 1.7 uranium a/o and surface temperatures ranged from about 1300 to $1550 \mathrm{~F}$. The results of the postirradiation examination, which were reported in detail in BMI-1366 and BMI-1377, revealed that all six specimens were in good physical condition.

The three remaining capsules have been in the MTR since the beginning of Cycle 125 (July 24, 1959) and have just completed their eleventh MTR cycle (Cycle 135). At the present time all capsule heaters are operating, three of the six thermocouples are operating in Capsules BMI-31-1 and BMI-31-2, and four of the six thermocouples are operating in Capsule BMI-31-3. Thermocouple 5 in Capsule BMI-31-2, which was listed as erratic in the previous report (BMI-1423), failed during this cycle. The thermocouple temperatures and the heater power requirements for maintaining capsules in the desired temperature range during Cycle 135 are reported in Table S-1. It was observed that approximately $400 \mathrm{w}$ of additional power was required over the Cycle 134 power requirements to maintain temperatures in Capsules BMI-31-1 and BMI-31-2, while BMI31-3 required approximately $160 \mathrm{w}$ of additional power.

TABLE S-1. TEMPERATURES AND ELECTRICAL-HEATER POWER CONSUMPTION FOR CAPSULES BMI-31-1, BMI-31-2, AND BMI-31-3 DURING MTR CYCLE 135

\begin{tabular}{|c|c|c|c|c|c|c|c|}
\hline \multirow[b]{2}{*}{ Capsule } & \multirow{2}{*}{$\begin{array}{c}\text { Electrical-Heater } \\
\text { Power Consumption, w }\end{array}$} & \multicolumn{6}{|c|}{ Thermocouple Reading(a) } \\
\hline & & No. 1 & No. 2 & No. 3 & No. 4 & No. 5 & No. 6 \\
\hline$B M I-31-1$ & 1350 & & & 1490 (b) & 1435 & 1250 & \\
\hline BMI-31-2 & 2600 & 1460 & & $1460(\mathrm{~b})$ & & & 1495 \\
\hline BMI-31-3 & 3050 . & 1465 & $1490^{(b)}$ & & 1485 & & 1455 \\
\hline
\end{tabular}

(a) Specimen surface temperatures are calculated to be 25 to $30 \mathrm{~F}$ higher.

(b) Controlling thermocouple. 
At present, it is planned to retain all three capsules in the MTR until the end of Cycle 143 (about August 1, 1960). By that time the specimens in Capsule BMI-31-1 will havi: approximately 20 to 25 uranium a/o burnup, while those in Capsules BMI-31-2 and BM]-31-3 will have approximately 12 and 9 uranium a/o burnup, respectively.

A single instrumented capsule containing $\mathrm{Al}_{2} \mathrm{O}_{3}-\mathrm{UO}_{2}$ samples was irradiated in the BRFi for six reactor cycles. This capsule has been sent to General Atomics for hot-cell exainination.

\section{Carbon-Transport Corrosion Studies}

N. E. Miller, D. J. Hamman, J. E. Gates, and W. S. Diethorn

Selected metal and graphite specimens have been exposed to radiation in heliumfille $\mathrm{d}$ quartz tori designed to promote convective flow of the helium and gaseous impur:ties past the specimens. All experimental work has been completed, and a topical repist has been issued (BMI-1419). No further work in this area is planned.

\section{Thermal Conductivity of Beryllia}

H. W. Deem and C. F. Lucks

An apparatus for measurement of thermal conductivity of beryllia is being fabricated. Attention is being given to making the apparatus versatile so that the inner structure can be changed readily to accommodate specimens of differing geometries. This meins that guard cylinder with accompanying specimen heater and heat sink can be eas:ly replaced in the vacuum envelope with another guard-cylinder assembly designed for a specimen of another geometry. A stainless steel guard assembly estimated to be capable of measuring temperatures to $1800 \mathrm{~F}$ will be used for the first measurements.

After the apparatus is calibrated using the more conventional stainless steel gua cd, it is planned to try a high-temperature ceramic guard. If the ceramic guard is satisfactory operating temperatures can be extended to $2000 \mathrm{~F}$ and above.

The apparatus should be completed, assembled, and calibrated during April.

Preparation and Coating of Uranium and Thorium Carbide Powders

J. H. Oxley, R. B. Landrigan, A. C. Secrest, C. F. Powell, and J. M. Blocher, Jr.

An experimental program is under way to determine the feasibility of preparing uraium and thorium carbide powders and, subsequently, to coat these powders with carjon, niobium carbide, or zirconium carbide films by vapor-deposition techniques. Parallel efforts on both preparation and coating are being carried out. 
An investigation of the kinetics of the deposition of carbon from methane in a fluidized bed was completed in March. Bed materials consisted of alumina, uranium dioxide, and uranium carbide powders. The effects of bed temperature, bed surface area, and methane partial pressure on the rate of deposition were tentatively correlated by the expression:

$$
W_{c}=\frac{1.25 \times 1013}{T_{B}} P_{C_{4}}^{1.04} e^{-\frac{87,310}{R T_{B}}} S_{B}^{0.54} e^{-\frac{4,290}{S_{B}}} \pm 18.7 \text { per cent }
$$

where

$$
\begin{gathered}
\mathrm{W}_{\mathrm{c}} \text { - rate of carbon deposition, } 0.03 \text { to } 2.20 \mathrm{~g} \text { per } \mathrm{hr} \\
\mathrm{T}_{\mathrm{B}} \text { - deposition temperature, } 1228 \text { to } 1398 \mathrm{~K} \\
\mathrm{P}_{\mathrm{CH}_{4}} \text { - methane partial pressure, } 253 \text { to } 760 \mathrm{~mm} \text { of mercury } \\
\mathrm{S}_{\mathrm{B}} \text { - surface area of the bed, } 2,690 \text { to } 10,550 \mathrm{~cm}^{2} .
\end{gathered}
$$

One experiment was carried out using acetylene as the source of carbon. The carbondeposition rate from acetylene is approximately 25 times the carbon-deposition rate from methane. Carbon films between 0.2 and $12 \mu$ thick were obtained, and the porosity of these films on uranium-containing powders is being determined by a leaching procedure.

Two experiments were performed on the deposition of uranium carbide from methane and uranium tetraiodide. The analyses of the product from the first of these runs revealed a carbon-to-uranium ratio of 9.0. Further analytical work is being undertaken to completely identify these deposits. 
DEVELOPMENTAL STUDIESS FOR THE SM-2 (ALCO)

S. J. Paprocki

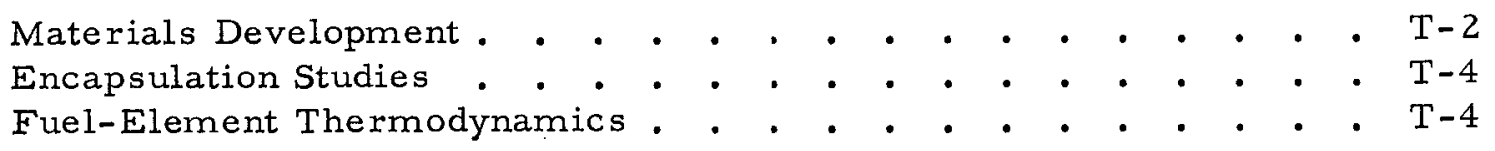

Studies covered in this section are being conducted in assistance to Alco Products and are concerned with the development of fuel, absorber, and suppressor materials for the SM-2.

Fuel plates of the SM-2 reference design and fuel plates embodying alternate fuel matırials have been fabricated. These fuel plates are being forwarded to Alco for fabrication into elements and irradiation in the SM- 1 .

Studies concerned with retention of boron and prevention of segregation of sphe rical $\mathrm{UO}_{2}$ have been continued. Spot analyses of fuel plates for boron and analyses of eiztire fuel plates indicate that boron losses can be controlled within 10 per cent by the iurrent process. The coating of $\mathrm{ZrB}_{2}$ with barrier materials such as niobium and tungsten appears to offer a possibility for retention of boron within the accuracy limits of analysis. Segregation of spherical $\mathrm{UO}_{2}$ has been essentially eliminated by the use of a special powder-blending process.

Three MTR capsules have been discharged and one ETR capsule containing SM-2 reference and alternate fuel test specimens will be discharged on April 4. These capsules will be returned to Battelle for postirradiation evaluation. Four additional instrumented capsules have been forwarded to the ETR. It is anticipated that three of these capsules will be inserted during the next reactor shutdown.

A program has been initiated with the objective of obtaining a better understanding if the thermodynamics involved between an SM-2 type fuel plate and a gaseous environment during sintering and rolling processes. The prime effort will involve the postulation of possible reactions and study by calculation; however, it is also planned to cisnduct experimental work as a supplement to these studies. 


\section{Materials Development}

S. J. Paprocki, D. L. Keller, G. W. Cunningham,

A. K. Foulds, and D. E. Lozier

Techniques are being developed and evaluated for the production of SM- 2 fuel elements, and process specifications will be written at the end of this fiscal year. Work on $\mathrm{Eu}_{2} \mathrm{O}_{3}$ dispersions for control materials has been delayed because of the major effort directed toward fabrication of fuel plates for insertion in the SM- 1 reactor.

\section{Fuel Materials}

Sixty full-size SM-2 fuel plates containing fully enriched uranium have been prepared. Thirty-eight of these plates will be shipped to Alco for incorporation in two fuel elements which will be inserted in the SM-1 Core 2 spike core. Fabrication data, including uranium and boron analyses on plates retained at Battelle, will be used as an aid in writing specifications for the production of SM-2 fuel plates. Fuel loadings, type of fuel, and burnable poison have been previously reported for these plates. Core measurements and total dimensional measurements have not been completed.

Dimensional data on nine half-size fuel plates to be used in WTR in-pile loops is shown in Table T-1. Analyses on plates retained at Battelle for metallography and uranium and boron analyses have not been completed.

Boron-retention studies have continued. As indicated in Table $T-2$, there is less than 3 per cent variation in boron content regardless of the particle size used. Since these samples are from sections of a large plate, a precise calculation of boron loss cannot be made, but the values shown for boron content actually represent a slight gain. Thus it appears that little or no loss occurred.

Metallographic examination of dispersions containing niobium-coated $\mathrm{ZrB}_{2}$ has been completed. The results indicate a slight reaction in the $\mathrm{ZrB}_{2}$ particles, but no reaction in the stainless matrix. Chemical analyses indicated that no boron loss occurred. Some difficulty was encountered in analyzing the coated $\mathrm{Zr}_{2}$ because of sampling problems, i.e., because all particles have the same thickness coating, the smaller particles have a higher weight percentage of niobium. However, it appears that consistent analyses can be obtained on closely sized particles. High-purity $\mathrm{ZrB}_{2}$ has been coated with a 4 to $5-\mu$ coating of niobium. Also, tungsten-coated $\mathrm{ZrB}_{2}$ has been prepared, and dispersions are being made to evaluate these powders.

As a check on the reference fabrication procedures, a full-size plate was selected at random from a series of fabricated plates and analyzed for boron. The entire plate was dissolved, and the total boron was determined. Analysis of this plate showed that 94.96 per cent of the boron was retained. Additional full-size plates will be analyzed.

Studies of the segregation of spherical $\mathrm{UO}_{2}$ have indicated that, by precoating the $\mathrm{UO}_{2}$ with a camphor-methanol binder, segregation can essentially be prevented. Recent work has shown that, if die punches are excessively lubricated, minor segregation can 
TABLE T -1 . CORE DIMENSIONS AND UO 2 WEIGHT OF WTR PLATES

\begin{tabular}{|c|c|c|c|c|c|c|c|c|}
\hline \multirow[b]{2}{*}{ Plate } & \multirow{2}{*}{$\begin{array}{l}\text { Camber, } \\
\text { in. }\end{array}$} & \multirow{2}{*}{$\begin{array}{c}\text { Nominal Active } \\
\text { Length, in. }\end{array}$} & \multirow{2}{*}{$\begin{array}{l}\text { Suppressor } \\
\text { Length, in. }\end{array}$} & \multirow{2}{*}{$\begin{array}{c}\text { Total } \\
\text { Length, in. }\end{array}$} & \multicolumn{3}{|c|}{ Width(a), in. } & \multirow{2}{*}{$\begin{array}{c}\mathrm{UO}_{2} \text { Weight, } \\
\mathrm{g}\end{array}$} \\
\hline & & & & & Point 1 & Point 2 & Point 3 & \\
\hline$W-5$ & 0.015 & 15.98 & 0.51 & 16.70 & 1.50 & 1.50 & 1. 51 & 24.577 \\
\hline$w-7$ & None & 15.83 & 0.50 & 16.68 & 1.49 & 1. 49 & 1. 495 & 23.959 \\
\hline$W-11$ & 0.010 & 16.01 & 0.48 & 16.56 & 1.50 & 1.51 & 1,51 & 24.621 \\
\hline$W-12$ & 0.003 & 16.04 & 0.50 & 16.59 & 1.50 & 1.50 & 1. 51 & 24.966 \\
\hline$W-8$ & 0.003 & 15,98 & 0.50 & 16.52 & 1. 50 & 1. 505 & 1. 51 & 24.782 \\
\hline$W-13$ & 0.012 & 15.99 & 0.50 & 16. 68 & 1. 50 & 1. 49 & 1. 50 & 24.402 \\
\hline$W-9$ & None & 15.74 & 0.47 & 16.40 & 1.50 & 1.50 & 1. 50 & 24.380 \\
\hline$W-10$ & None & 15.82 & 0.51 & 16.57 & 1.495 & 1.495 & 1.50 & 24.407 \\
\hline$w-3$ & 0.020 & 16.11 & 0.51 & 16.72 & 1.50 & 1. 505 & 1. 51 & 24.453 \\
\hline
\end{tabular}

(a) Pcsition of the width measurements: Point 1,2 in. from the numbered end; Point 2, center line; and Point 3,2 in. from the suppressor end of the core.

TABLE T -2. EFFECT OF ZrB 2 PARTICLE SIZE ON BORON CONTENT OF SM -2 FUEL PLATES

\begin{tabular}{ccc}
\hline $\begin{array}{c}\text { Particle Size, } \\
\text { mesh }\end{array}$ & $\begin{array}{c}\text { Boron Loading, } \\
\text { w/o }\end{array}$ & $\begin{array}{c}\text { Calculated } \\
\text { Boron Content (a), } \\
\text { w/o }\end{array}$ \\
\hline$-100+200$ & 0.230 & 0.247 \\
$-200+270$ & 0.230 & 0.254 \\
$-270+325$ & 0.230 & 0.250 \\
\hline
\end{tabular}

(a) Chemical analyses were obtained on sections of plate including cladding. Calculated value is obtained by measuring cladding thickness and estimating core weight. 
be caused by $\mathrm{UO}_{2}$ sticking to the punch faces. In order to prevent this behavior, it is desirable to lubricate the punches lightly with a quick-drying lubricant. A small amount of work will be continued to determine how much care is required in handling the powders and loading the dies.

\section{Encapsulation Studies}

J. F. Lagedrost, W. E. Murr, J. H. Stang

Three noninstrumented capsules, BMI-32-1, BMI-32-2, and BMI-32-3, containing SM-2 reference and alternate fuels, were discharged from the MTR core on March 28 following irradiations of 11,10 , and 9 reactor cycles, respectively. Calculated specimen-surface temperatures at the start of these irradiations were in the desired range; estimated total burnups at discharge for the peak-flux specimens are 73, 75 , and 62 a/o, respectively. Postirradiation studies will begin at the BMI Hot-Cell Facility about mid-April.

The first of seven instrumented capsules, BMI-32-4, is scheduled to be discharged from the ETR beryllium reflector on April 4, following an eight-cycle irradiation. Although all instrumentation in this capsule failed prematurely (the final thermocouple failed during the seventh cycle), accumulated data indicate that the upperspecimen surfaces probably were in the 600 to $700 \mathrm{~F}$ range during most of the irradiation. The estimated total burnup for the peak-flux specimen in BMI-32-4 at discharge will be $41 \mathrm{a} / 0$. Postirradiation studies at the hot cells are scheduled to begin during the latter part of April.

Four additional instrumented capsules have been sent to the ETR. Of these, BMI-32-5, BMI-32-6, and BMI-32-8 are scheduled for insertion in the reactor during the early-April shutdown. Assembly of the final two capsules, BMI-32-7 and BMI-32-10, is being delayed until performance of the above three can be observed and any necessary modifications devised. It is probable that these can be as sembled in time for a June or July insertion.

\section{Fuel-Element Thermodynamics}

J. J. Ward, C. A. Alexander, A. W. Lemmon, Jr., and R. B. Filbert, Jr.

An effort was initiated on a program to study the thermodynamics of postulated reactions between fuel-element materials and between fuel-element materials and surrounding atmospheres. Of primary interest are those reactions which could lead to boron loss during fabrication of the current SM-2 element. Future interest will be in alternate materials and their possible reactions.

In studying the thermodynamics of the postulated reactions, the primary approach is a calculational one. At the present time, the experimental work being performed is designed to complement the calculational effort by providing basic thermodynamic data; 
however, at a later stage, the experimental effort may serve to prove the results obtainizd by calculation through the performance of definitive experiments.

Work began this month with a systematic attempt to write all of the chemical reactions which could be postulated for the fuel-element materials and the gases in the suryounding atmosphere. Initially, no consideration was given to the likelihood of any particular reaction being possible. But, as this effort progressed, judgement was introduced into the process, and the possibility of the occurrence of each reaction is being evaluated on a qualitative basis. Later, as more information is developed and made available, a quantitative evaluation will be made. At this time, approximately 300 chemical reactions have already been postulated.

In order to evaluate quantitatively the postulated reactions, reliable thermodynémic data must be available. Therefore, effort is also being expended in assemblin the best data available from the literature and in developing, by evaluation and calculation, the most likely values for use. During March, an effort was made to obtain standard free-energy data over the range from 298 to $1800 \mathrm{~K}$ for zirconium diboride, an important fuel-element constituent.

A summary of the results is given in Tables $T-3$ and $T-4$. The data shown were calculated from an experimental heat of combustion, an estimated entropy of formation, and the heat content of $\mathrm{ZrB}_{2}$ obtained f:om the Russian literature. The heat content; for zirconium and boron were taken from the work of the U. S. Bureau of Mines.

TABLE T -3. HEAT-CAPACITY EQUATIONS

\begin{tabular}{|c|c|c|c|}
\hline Compound & $\begin{array}{l}\text { Temperature Range } \\
\text { of Validity }(T), \mathrm{K}\end{array}$ & $\begin{array}{l}\text { Heat Capacity(a), Cp, } \\
\text { cal } /(\mathrm{g} \text { mole)(K) }\end{array}$ & Literature Source \\
\hline \multirow[t]{2}{*}{ Zirconium diboride, $\mathrm{Z}_{\mathrm{rB}}$} & $273-1073$ & $\begin{array}{r}11.78+9.99 \times 10^{-3} \\
\mathrm{~T}-4.03 \times 10^{-6} \mathrm{~T}^{2}\end{array}$ & $\begin{array}{l}\text { Krestovnikov, A. N., and Vendrikh, M. S., } \\
\text { Izvestiga Vysshikh Ucheonykh Zavedeniy T } \\
\text { Svetnaya Metallurgiya, No. 1, p } 73 \text { (1955) }\end{array}$ \\
\hline & $1073-3263$ & $15.93+1.78 \times 10^{-3} \mathrm{~T}$ & Estimated \\
\hline \multicolumn{4}{|l|}{ Zirconium } \\
\hline A pha & $298-1135$ & $\begin{array}{l}6.83+1.22 \times 10^{-3} \\
\mathrm{~T}-0.91 \times 10^{+5} \mathrm{~T}^{-2}\end{array}$ & $\begin{array}{l}\text { King, E. G. , and Coughlin, J. P., J. Am. } \\
\text { Chem. Soc. , } 72,2262(1950)\end{array}$ \\
\hline Be:ta & $1135-1400$ & 7.27 & Ditto \\
\hline . & $1400-1800$ & 7.27 & Estimated \\
\hline \multirow[t]{2}{*}{ Boron } & $293-1100$ & $1.54+4.40 \times 10^{-3} \mathrm{~T}$ & $\begin{array}{l}\text { Kelley, K. K. . "Contributions to the Data } \\
\text { on Theoretical Metallurgy", U. S. Bur. } \\
\text { Mines Bull. } 476 \text { (1949) }\end{array}$ \\
\hline & $1100-2373$ & $5.60+0.71 \times 10^{-3} \mathrm{~T}$ & Estimated \\
\hline
\end{tabular}

$\overline{\text { (a) } \mathrm{T}} \overline{\mathrm{K}} \mathrm{K}$. 
TABLE T -4. THERMOCHEMICAL EQUATIONS FOR THE STANDARD CHEMICAL REACTION OF FORMATION: $\mathrm{Zr}(\mathrm{c})+2 \mathrm{~B}(\mathrm{c}) \geqslant \mathrm{Z}$ IB 2 (c)

\begin{tabular}{|c|c|c|}
\hline Standard Heat of Formation, $\Delta \mathrm{H}_{\mathrm{f} 298}^{\circ}$ & $-75,000$ cal per $\mathrm{g}$ mole & $\begin{array}{l}\text { "Transactions of the Conference on Chemistry of } \\
\text { Boron and Its Compounds", Moscow, } 1958 \\
\text { (GKhI); estimated from value for } \Delta H \text { combustion } \\
\text { of } \mathrm{ZrB}_{2.05}, \text { p } 101\end{array}$ \\
\hline Entropy of Formation, $\Delta s_{f 298}^{\circ}$ & $-5.4 \mathrm{cal} /(\mathrm{g}$ mole $)(\mathrm{K})$ & Ibid (p 14) \\
\hline Standard Free Energy of Formation, $\Delta \mathrm{F}_{\mathrm{f} 298}^{\circ}$ & $-73,390$ cal per g mole & Computed \\
\hline $\begin{array}{l}\text { Standard Equation for Free Energy of Formation } \\
\text { as a Function of Temperature }(298 \text { to } 1087 \mathrm{~K})^{(\mathrm{a})} \text {, } \\
\text { cal per } \mathrm{g} \text { mole }\end{array}$ & \multicolumn{2}{|c|}{$\Delta \mathrm{F}_{\mathrm{T}}^{\circ}=-75,220-4.31 \mathrm{~T} \log _{10} \mathrm{~T}-0.04 \times 10^{-3} \mathrm{~T}^{2}+0.67 \times 10^{-6} \mathrm{~T}^{+3}-0.46 \times 10^{+5} \mathrm{~T}^{-1}+17.27 \mathrm{~T}$} \\
\hline $\begin{array}{l}\text { Standard Equation for Heat of Formation (298 to } \\
1087 \mathrm{~K})^{(\mathrm{a})} \text {, cal per } \mathrm{g} \text { mole }\end{array}$ & \multicolumn{2}{|c|}{$\Delta \mathrm{H}_{\mathrm{T}}^{\circ}=-75,220+1.87 \mathrm{~T}+0.04 \times 10^{-3} \mathrm{~T}^{2}-1.34 \times 10^{-6} \mathrm{~T}^{3}-0.91 \times 10^{+5} \mathrm{~T}^{-1}$} \\
\hline $\begin{array}{l}\text { Heat Content of } \mathrm{ZrB}_{2}(298 \text { to } 1087 \mathrm{~K})^{(\mathrm{a})} \text {, } \\
\text { cal per } \mathrm{g} \text { mole }\end{array}$ & \multicolumn{2}{|c|}{$\mathrm{H}_{\mathrm{T}}-\mathrm{H}_{298}=11.78 \mathrm{~T}+5.00 \times 10^{-3} \mathrm{~T}^{2}-1.34 \times 10^{-6} \mathrm{~T}^{3}-3920$} \\
\hline
\end{tabular}

(a) $\mathrm{T}=\mathrm{K}$. 
In selecting the heat of formation of zirconium diboride, two values were available. One gave $\Delta \mathrm{H}_{\mathrm{f} 298}^{\circ}$ as $-63,100$ and the other as $-75,000$ cal per $\mathrm{g}$ mole. The former was based on an equilibrium vapor pressure of the following reaction by Samisanov*:

$$
1 / 2 \mathrm{~B}_{4} \mathrm{C}(\mathrm{c})+\mathrm{ZrO}_{2}(\mathrm{c})+3 / 2 \mathrm{C} \text { (graphite, excess) } \rightleftharpoons \mathrm{ZrB}_{2}(\mathrm{c})+2 \mathrm{CO}(\mathrm{g}) \text {. }
$$

The latter value was determined by the direct combustion of $\mathrm{ZrB}_{2.05}$ in an oxygenbomls calorimeter by Epel'baum and Starostina. Since the latter value is direct, and not clependent on an uncertain attainment of equilibrium, it was accepted as the best valus.

A standard entropy-change value based on estimations was taken from the USSR literature. Heat capacities for the elements and $\mathrm{ZrB}_{2}$ were available, as indicated in Table T-3, to around $1100 \mathrm{~K}$. Estimated values are given to $1800 \mathrm{~K}$.

In an effort to confirm the value for the free energy of formation of $\mathrm{ZrB}_{2}$, an experimental program has been started. Five possible reactions (and/or methods) have been considered for the planned experiments:

(1) Volatility measurements in a vacuum (perhaps containing traces of oxygen or water vapor)

(2) Oxidation by $\mathrm{CO}_{2}$

(3) A solid-phase reaction between $\mathrm{ZrO}_{2}, \mathrm{~B}_{4} \mathrm{C}$, and carbon to produce $\mathrm{ZrB}_{2}$ and $\mathrm{CO}$

(4) An oxygen-bomb combustion

(5) An emf determination.

Lack of reliable data on the other compounds involved in the reactions of methods (1) and 13) makes them somewhat unattractive, while the long experimental run times involved in a series of experiments like Method (2) make it seem advantageous to find some other means. Although encouraging preliminary results have been obtained for Method (4), a sizable experimental program would be required to obtain a set of values no more reliable than those currently available in the literature. Consequently, first consideration is being given to Method (5), which has no obvious disadvantages. However, polarization phenomena, contact potentials, and the question of reversibility of the cell are all possible obstacles in making reproducible measurements. Such obsticles cannot be predicted, though, and, since there are obvious disadvantages in the cther methods, the first experimental efforts are being directed toward the EMF metrod.

Efforts along these lines will be continued during the following months.

"Sams jnov, G. V., "Heats of Formation of Some Transition Metals", Zhur. Fiz. Khem. . 30, 2057-60 (1958). 
GAS-COOLED REACTOR PROGRAM (AGN)

\author{
D. L. Keller
}

\begin{abstract}
Fabrication of $\mathrm{BeO}-\mathrm{UO}_{2}$ Fuel Pellets . . . . . . . . . . . . U U-2 Study of Processing Variables in the Fabrication of $\mathrm{BeO}-\mathrm{UO}_{2}$

Ceramics. . . . . . . . . . . . . . . . . . U-2

Encapsulation Studies .................. U U 4

Effects of Irradiation . . . . . . . . . . . . . . . . U U-5

Alloy Modification of Hastelloy X. . . . . . . . . . . . . U-6

GCRE Critical-Assembly Experiments . . . . . . . . . . U U-7

BRR Loop Program . . . . . . . . . . . . . . . . . U U-7

ETR Loop Program. . . . . . . . . . . . . . . . . U-8
\end{abstract}

Studies for Aerojet-General Nucleonics (AGN) and the Army Reactor Branch (ARIA) directed toward the development of compact gas-cooled reactors are reported in this section.

Fabrication studies on $\mathrm{BeO}-\mathrm{UO}_{2}$ fuel pellets have been broadened to include a study of more economical methods of preparing the desired pellets. Reduction in sintering times and temperatures, evaluation of improved binders and lubricants, and the recycling of rejected pellets will be considered.

The $\mathrm{BeO}-\mathrm{UO}_{2}$ fuel pellets clad in Hastelloy $\mathrm{X}$ and irradiated to approximately 1.8 a/o uranium burnup are being examined. In general, the clad specimens and pellets appear in good condition after operation at surface temperatures of about $1700 \mathrm{~F}$.

In another materials program the effect of alloying additions which may improve both the oxidation resistance and ductility of Hastelloy $\mathrm{X}$ after exposure to a nitrogen$1 / 2$ volume per cent oxygen mixture is being studied. Ingots in which niobium and yttrium have been added and the carbon, chromium, and nickel content varied have been prefared and, subsequently, forged and rolled into sheet stock. Difficulty was encour tered with only one alloy during fabrication.

A critical-assembly program is being conducted to investigate the physics and engineering characteristics of the ARM's portable gas-cooled reactor, ML-1-1B. Final cheskouts were completed of the assembly, and experimentation is expected to begin next month.

An in-pile-loop program is concerned with the design, construction, and operation of $r$ circulating gas loops for the evaluation of fuel subassemblies. At the Battelle Reseajch Reactor, the sixth specimen irradiation was started. At the Engineering Test Reaztor preparation for the initial specimen irradiation was continued. 
Pellets of $\mathrm{BeO}-25$ volume per cent $\mathrm{UO}_{2}$ are being prepared for loop exposure. During March an additional supply of MCW ceramic grade minus 325-mesh, fully enriched $\mathrm{UO}_{2}$ was received, and fabrication of an additional 4000 pellets for loop exposure was started. About half of the required pellets have been produced. It is estimated that this work will be completed during April.

Study of Processing Variables in the Fabrication of $\mathrm{BeO}-\mathrm{UO}_{2}$ Ceramics

H. D. Sheets, A. K. Smalley, and W. Duckworth

The broad objective of this project is to develop ceramic engineering practices that will permit the manufacture of high-quality $\mathrm{BeO}^{-\mathrm{UO}_{2}}$ pellets in the most economical manner.

Briefly, the process for manufacture consists of intimately blending a mixture of $40 \mathrm{w} / \mathrm{o} \mathrm{BeO}$ powder and $60 \mathrm{w} / \mathrm{o}$ enriched $\mathrm{UO}_{2}$ powder with an organic binder, pressing pellets, and then sintering. The selection of the $\mathrm{BeO}$ and $\mathrm{UO}_{2}$ starting powder is critical in this process. Such factors as the conditions for blending, the type and amount of binder, the pressing pressure, and the sintering conditions required to obtain a pellet of satisfactory density and soundness depend on the character of the starting powders.

In a recent pilot-scale production of $\mathrm{UO}_{2}-\mathrm{BeO}$ pellets, the temporary binders used were less than satisfactory. It was difficult to obtain a uniform dispersion of the binder in the powdered materials under the mixing conditions employed. Also, pellets had a tendency to stick to the male parts of the die. Table U-1 lists batch compositions, pressing characteristics, and sintered properties of pellets prepared in an investigation of other binders. Batch 9-6 appeared to have satisfactory pressing characteristics. Examination of sintered specimens by radiography and under a microscope indicated that specimens made from Batch $9-6$ were uniform and free of laminations.*

It is planned to give early attention to the effects of reducing sintering temperature and time and the recycling of sintering rejects on pellet quality, as determined by bulk density and uniformity of fuel dispersion.

\footnotetext{
The ash content of the binder employed was $0.2 \mathrm{w} / \mathrm{O}$; spectrographic analysis indicated that sodium was the major constituent of the ash.
} 
TABLE U-1. EVALUATION OF VARIOUS BINDERS AND LUBRICANTS FOR PRESSING(a) BeO-UO ${ }_{2}$ POWDERS

\begin{tabular}{|c|c|c|c|c|c|c|c|c|}
\hline \multirow[b]{2}{*}{ Batch } & \multicolumn{2}{|c|}{ Binder } & \multicolumn{2}{|c|}{ Lubricant } & \multirow[b]{2}{*}{ Comments } & \multicolumn{2}{|c|}{ Bulk Density } & \multirow{2}{*}{$\begin{array}{c}\text { Diametral } \\
\text { Shrinkage, } \\
\text { per cent }\end{array}$} \\
\hline & Material & $\begin{array}{c}\text { Amount Added, } \\
\text { w/o }\end{array}$ & Material & $\begin{array}{c}\text { Amount Added, } \\
\text { w/o }\end{array}$ & & $\mathrm{G}$ per $\mathrm{Cm}^{3}$ & $\begin{array}{l}\text { Per Cent of } \\
\text { Theoretical }\end{array}$ & \\
\hline $8-1$ & Polyvinyl alcohol ${ }^{(b)}$ & 1.5 & Sterotex $(c)$ & 0.3 & $\begin{array}{l}\text { Specimens stuck to pin; microscopic } \\
\text { examination indicated nonuniform } \\
\text { powder }\end{array}$ & 5.02 & 95 & 22.0 \\
\hline $8-2$ & Polyvinyl alcohol & 2.0 & Sterotex & 0.4 & Ditto & 4.99 & 95 & 21.8 \\
\hline $8-3$ & Carbowax $4000^{(d)}$ & 2.0 & -- & - & $\begin{array}{l}\text { Specimens stuck to die cavity and } \\
\text { punches }\end{array}$ & 5.23 & 99 & 22.2 \\
\hline $9-4$ & Nopco CD-108 ${ }^{(e)}$ & 3.0 & -- & -- & Specimens stuck to pin & 5.23 & 99 & -- \\
\hline $3-5$ & Nopco $C D=110(e)$ & 3.0 & -- & $-=$ & $\begin{array}{l}\text { Specimens stucle to die cavity and } \\
\text { punches }\end{array}$ & 5.17 & 98 & - \\
\hline $9-6$ & Nopco CD-108 & 4.0 & -- & $\because$ & Satisfactory & 5.22 & 99 & 21.5 \\
\hline $9-7$ & Nopco CD-110 & 4.0 & -- & - & Specimens stuck to pin & 5.03 & 96 & 21.0 \\
\hline $9-8$ & $\begin{array}{l}\text { Polyvinyl alcohol } \\
\text { Carbowax } 4000\end{array}$ & $\begin{array}{l}1.0 \\
1.0\end{array}$ & $=$ & -- & $\begin{array}{l}\text { Specimens stuck to pin, die cavity, } \\
\text { and punches }\end{array}$ & 5.04 & 96 & -- \\
\hline $9-9$ & Polyvinyl alcohol & 1.5 & Ceremul "C"(f) & 1.0 & Specimens laminated & 5.03 & 96 & - \\
\hline
\end{tabular}

(a) Pressed specimens were hollow, right-circular cylinders, about 0.25 in. in diameter.

(b) 98 per cent hydrolized. Matheson, Coleman, and Bell, Norwood, Ohio.

(c) Capital City Products Company, Columbus, Ohio.

(d) Union Carbide Chemicals Company, Charleston, West Virginia.

(e) Nopco Chemical Company, Newark, New Jersey.

(f) Sacony-Vacuum Oil Company, New York, New York. 
Irradiation of Specimens Containing MCW Spherical UO2 Dispersed in Stainless Steel

This program has the objective of comparing the radiation stability of MCW spherical and ORNL hydrothermal $\mathrm{UO}_{2}$ dispersed in stainless steel. Two clad, flatplate specimens of each type, containing $30 \mathrm{w} / 0$ highly enriched $\mathrm{UO}_{2}$, were irradiated in thermocoupled Capsules BMI-33-1 and BMI-33-2, which were discharged from the MTR on March 28.

Both capsules are scheduled to be returned to the BMI Hot-Cell Facility early in April for postirradiation studies. Following are brief histories of the irradiations.

BMI-33-1. This capsule was irradiated in MTR Position A-40-SW during Cycles 131 through 136 (November 25, 1959, to March 28, 1960). Specimen center-line temperatures (calculated from observed thermocouple readings) ranged from $1315 \mathrm{~F}$ (top specimen) to $1100 \mathrm{~F}$ (bottom specimen) at the start of the irradiation. Corresponding temperatures at the end of the exposure were about $300 \mathrm{~F}$ lower. Calculated specimen fission burnups range approximately from 12 to $15 \mathrm{a} / \mathrm{o}$.

BMI-33-2. This capsule (identical to BMI-33-1) was inserted in Position A-6-NE for Cycle 133 (January 8 to 25,1960 ) and then transferred to A-6-NW for Cycles 134, 135, and 136 (February 1 to March 28, 1960). Although quoted fluxes in Position A-6$\mathrm{NE}$ were 25 per cent higher than those in $\mathrm{A}-40-\mathrm{SW}$, specimen temperatures during Cycle 133 were essentially the same as those in BMI-33-1. The move to A-6-NW resulted in higher temperatures; calculated specimen center-line temperatures ranged from 1550 to $1280 \mathrm{~F}$ at the start of Cycle 134. By the end of Cycle 136, the corresponding levels were as much as $200 \mathrm{~F}$ lower. Estimated fission burnups for the various specimens range from $9-1 / 2$ to $11-1 / 2$ a/o for the four-cycle exposure.

$\mathrm{UO}_{2}-\mathrm{BeO}$ Irradiation Studies

This program is concerned with an evaluation of high-temperature irradiation effects on Hastelloy $\mathrm{X}$-clad (highly enriched) $\mathrm{UO}_{2}-\mathrm{BeO}$ dispersions. Six specimens each containing six fueled pellets were irradiated in a double-wall fully instrumented capsule exposed in BRR Core Position 45. The capsule was discharged on March 8, 1960 , after four 2-week reactor cycles.

The unperturbed and effective thermal fluxes at the central specimen location were estimated by nuclear mock-up experiments to be $4.2 \times 10^{13} \mathrm{nv}$ and $1.3 \times 10^{13} \mathrm{nv}$, respectively, with the reactor at full power (2 megawatts). However, results of capsule temperature-versus-electrical power input calibrations (with reactor coolant water flowing) indicated a peak effective flux of $0.86 \times 10^{13} \mathrm{nv}$. Also, a calculated effective flux of $0.76 \times 10^{13} \mathrm{nv}$ would be necessary to produce observed thermocouple temperatures of 1300 to $1400 \mathrm{~F}$ caused by fission and gamma heat only. Based on the mean of 
these two determinations, the estimated total uranium burnup (fission plus capture) is apprisximately 2.2 a/o. Cladding-surface termperatures of the second, third, and fourth specimens from the capsule top were in the desired temperature range of 1700 to $1750 \mathrm{~F}$ for approximately 748 of the $891 \mathrm{hr}$ of the reactor operating time at 2 megawatts.

Immediately after discharge from the reactor, the capsule was transported to the Batt $\in 11$ e Hot-Cell Facility for disassembly and specimen evaluations.

\section{Effects of Irradiation}

J. H. Saling, D. G. Freas, J. E. Gates, and R. F. Dickerson

A study of the effects of irradiation on Hastelloy $\mathrm{X}$-clad pins containing pellets of $\mathrm{BeO}$ fueled with $\mathrm{UO}_{2}$ is in progress. Six pins, each containing four pellets of $59 \mathrm{w} / \mathrm{o}$ (nominal) fully enriched $\mathrm{UO}_{2}$ dispersed in $\mathrm{BeO}$ and two end pellets of $44 \mathrm{w} / \mathrm{o}$ (nominal) fully enriched $\mathrm{UO}_{2}$ dispersed in $\mathrm{BeO}$, were irnmersed in $\mathrm{NaK}$ and sealed in a doublewall-type capsule. This capsule, equipped with thermocouples and electrical heaters, was 1 radiated for four reactor cycles in the BRR at specimen-surface temperatures of about $1725 \mathrm{~F}$. The extimated fission burnup of the test fuel pellets was approximately 1.8 . $/ \%$ of the uranium.

The postirradiation examination of these specimens has been partially completed. The capsule was sampled for fission-gas content and then opened to permit recovery of the specimens. The clad pins were visually examined with a stereomacroscope, and all appeitred to be in good condition. There was no visible evidence of cracks in the cladding, although an initial check of the gas samples obtained from the capsule gave an indication of the presence of fission gas. Measurements of pin dimensions and density showed that any changes that occurred during irradiation were negligible. The gas containe $\mathrm{I}$ in two pins, one from the highest and one from the lowest temperature regions in the capsule, was sampled for fission-gas content. The analyses of the gas obtained from the pins and the capsule are now in progress. The two pins from which the gas samfles were obtained were then opened by cutting the ends of the pins with an abrasive cutof: wheel, and the pellets were removed.

All of the pellets appeared to be in good condition. Dimensional measurements of the pellets did not show any significant changes resulting from the irradiation, although density measurements performed by immersion techniques showed decreases in density ranging from about 1 to 2 per cent.

One pellet recovered from each of the two specimens was selected for burnup analysis, and also one pellet from each of the two specimens was selected for metallograplic examination along with a longitudinal cross section of the Hastelloy $\mathrm{X}$ cladding. Burnup analyses and metallographic examinations are in progress. 


\section{Alloy Modification of Hastelloy X}

J. A. DeMastry, A. A. Bauer, and R. F. Dickerson

Hastelloy $X$ has been selected as a cladding material in the GCRE. A loss in tensile ductility (from 40 per cent total elongation to 12 per cent total elongation) has been observed in specimens which were exposed to a nitrogen plus $1 / 2$ volume per cent oxygen atmosphere at $1750 \mathrm{~F}$ for $5000 \mathrm{hr}$. This loss in ductility is not serious, but further exposure $(10,000 \mathrm{hr})$ may result in an additional loss in ductility which could lead to cladding failures. It is believed that either grain growth or carbide precipitation may be responsible for the loss of ductility observed. Losses in ductility due to grain growth may be overcome by adding a grain refiner such as yttrium. If carbides in the grain boundaries are embrittling the material, a more favorable phase distribution or a ductile matrix for carbide precipitation may be obtained by adding niobium or yttrium.

The effects of alloying additions which may improve both the oxidation resistance and the ductility after exposure to a nitrogen-1/2 volume per cent oxygen mixture are being studied. Niobium and yttrium are being added for this purpose. The effects of variations in the chromium and nickel contents at the expense of the iron content are being investigated, and the carbon content is also being varied. The base alloy is nickel- $21 \mathrm{w} / 0 \mathrm{chromium}-20 \mathrm{w} / 0$ iron- $10 \mathrm{w} / 0$ molybdenum- $0.7 \mathrm{w} / \mathrm{o}$ tungsten- $1.0 \mathrm{w} / \mathrm{o}$ mangane $\mathrm{se}-1.0 \mathrm{w} / 0$ silicon $-0.1 \mathrm{w} / 0$ carbon.

One-kilogram ingots were induction melted in alumina crucibles and poured at $2900 \mathrm{~F}$ into Zirconite molds. The ingots were forged to $3 / 8-\mathrm{in}$. slabs at $2200 \mathrm{~F}$ and then rolled to $0.060-$ in. sheet at $2200 \mathrm{~F}$. Successful reductions of 95 per cent were obtained with all alloys except one containing a $1.5 \mathrm{w} / \mathrm{o}$ yttrium addition and $25 \mathrm{w} / \mathrm{o}$ instead of $21 \mathrm{w} / 0$ chromium; this alloy fractured during forging. A duplicate ingot has been prepared.

A portion of the fabricated sheet was sent to AGN for oxidation testing. Tensile specimens for tests at $75,1000,1750$, and $1850 \mathrm{~F}$ in air are being prepared from the remaining sheet.

The results of chemical analyses of the alloys for yttrium have been obtained. The yttrium was overcharged to the extent of 100 per cent in anticipation of losses during melting. However, the losses were lower than expected with the result that the yttrium contents are approximately 50 per cent higher than originally planned. This is not expected to interfere with the investigation. Analysis of one of the alloys which was intended to contain $0.5 \mathrm{w} / 0$ yttrium indicated a complete los s yttrium. A duplicate alloy is being prepared as a replacement.

Samples for examination of both the as-cast and wrought microstructures are being processed. 


\section{GCRE Critical-Assembly Experiments}

J. W. Ray, R. G. Matthews, W. S. Hogan, D. A. Dingee, and J. W. Chastain

A program is being conducted to investigate physics and engineering characteristics of the ML-1-1B, the Army portable gas-cooled reactor. The reactor is fueled with $\mathrm{UO}_{2}$ pins and is water moderated. During the month, construction, checkouts, and fina.. adjustments were completed on the critical assembly. The instrumentation was installed and calibrated and a simulated approach to criticality (no fuel in the core) was performed. This served to further calibrate instrumentation and to uncover any oversights in the construction of the critical assembly. Cadmium-indium control blades clad with stainless steel were constructed and installed to replace the former stainless steel-clad cadmium control blades.

Next month experimentation with the reactor will begin. The fuel is scheduled to arrive at Battelle the first week in April, and it is expected that initial criticality, reactor calibration, and a number of flux measurements will be accomplished during the month.

\section{BRR Loop Program}

W. G. Rieder, S. J. Basham, and W. H. Croldthwaite

The irradiation of an Aerojet General INucleonics fuel subassembly designated 1B-iT-2 was started on March 9. The specimen design features 19 fuel pins consisting of 0.241-in. -OD by 0.180-in. -ID Hastelloy tubing, $\mathrm{UO}_{2}$ pellets, and top and bottom welded closures.

The experiment has operated $339 \mathrm{hr}$ with specimen outlet-gas temperatures up to $1239 \mathrm{~F}$ and powex generation at a maximum of $40 \mathrm{kw}$. Plans call for continuation of stealy-state operation for a total of $500 \mathrm{hr}$ before a series of 500 thermal cycles.

The calibration of the continuous loop gas-monitoring system was continued during initial loop operation. Additional operational. data will be obtained before the calibration is complete.

The reduction of data from the flux run with the $1 \mathrm{~B}-2 \phi \mathrm{T}$ was started during March and should be completed during April. 
E. O. Fromm, J. V. Baum, A. M. Rockwood, and G. A. Francis

The primary activity during March was directed toward preparation for irradiation of the initial specimen in the BMI-16 loop.

The blower-drive modifications were completed at Battelle, and the components were returned to the reactor site. The installation of the loop blowers and the insertion of the 1-3P are scheduled for the next reactor shutdown, which should start in early April and last through the month.

The blower-life test at Battelle was continued through the month. The unit which had been on test was run for a total of $1011 \mathrm{hr}$ with one belt. At this point, after approximately $1800 \mathrm{hr}$ without bearing regreasing, inspection revealed no indication of incipient belt or bearing failure.

The test is being continued without regreasing but with a new belt and modified pulleys. Since the initial 1011-hr run demonstrated the acceptability of the original belt, the value of this run is to determine whether increased life can be expected from the new belt.

A summary report on the loop design was completed during March and will be is sued as BMI- 1429. 


\title{
CORROSION OF THORIUM AND URANIUM UNDER STORAGE CONDITIONS (LIVERMORE)
}

P. D. Miller

\begin{abstract}
Electrodeposited Coatings for Thorium (SC) . . . . . . . . . . V-2
Corrosion Evaluations (UCRL) . . . . . . . . . . . . . . . . V-2
\end{abstract}

Preliminary work is under way on a program to develop electrodeposited coatings on thurium. The preparation of the thorium surface for coating deposition will be studied first. Delays in material procurement have prevented initiation of experimental work in the program on determining the resistance of uranium and thorium and urani $1 m$ alloys to corrosion under storage conditions. 
$\mathrm{V}-\underline{\underline{2}}$

Electrodeposited Coatings for Thorium (SC)

John G. Beach and C. L. Faust

The protection of thorium components against corrosion and oxidation during storage is needed to maintain dimensional tolerances and to avoid excessive scatter of thorium corrosion products. Electroplated coatings will be investigated toward attaining the needed protection.

Experimental work will be started with thorium samples that are to be furnished by Sandia (Livermore). The quality of a protective-coating system will depend, in part, on the nature of the thorium surface. The kind of surface needed, including that attained by chemical and electrochemical finishing of the thorium, will be investigated to provide the needed surface for sound electroplated coatings.

\section{Corrosion Evaluations (UCRL)}

E. F. Stephan, P. D. Miller, and F. W. Fink

Plans are being made to determine the durability of bare and coated thorium, uranium, and certain uranium alloys under atmospheric conditions. The initial work will consist in evaluating these materials under the following laboratory conditions:

(1) Extended exposure in 100 per cent relative humidity at $120 \mathrm{~F}$

(2) Cyclic exposure involving periods of $20 \mathrm{hr}$ in air saturated with water at $160 \mathrm{~F}$ followed by freezing temperature for $4 \mathrm{hr}$

(3) Extended exposure in standard 20 per cent salt spray

(4) Extended exposure in an unheated warehouse.

The delivery of materials has been delayed so that experiments will probably not be started until sometime in April.

RWD/CR T: all 